\title{
Isotope- and REE-Characterization of Groundwater Aquifers
}

\author{
Dissertation \\ zur Erlangung des mathematisch-naturwissenschaftlichen Doktorgrades \\ "Doctor rerum naturalium" \\ der Georg-August-Universität Göttingen \\ im Promotionsprogramm Geowissenschaften / Geographie \\ der Georg-August University School of Science (GAUSS)
}

vorgelegt von

Manussawee Hengsuwan

aus Trang, Thailand

Göttingen 2016 


\section{Betreuungsausschuss:}

Prof. Dr. Bent T. Hansen, Abteilung Isotopengeologie, GZG

Dr. Klaus Wemmer, Abteilung Isotopengeologie, GZG

\section{Mitglieder der Prüfungskommission}

Referent: Prof. Dr. Bent T. Hansen, Abteilung Isotopengeologie, GZG

Korreferent: Dr. Klaus Wemmer, Abteilung Isotopengeologie, GZG

weitere Mitglieder der Prüfungskommission:

Prof. Dr. Volker Thiel

Prof. Dr. Andreas Pack

Dr. Christine Heim

Dr. Klaus Simon

Tag der mündlichen Prüfung: 20.05.2016 


\section{ACKNOWLEDGEMENTS}

Most Notably, I would like to thank the DAAD for providing funding for my PhD scholarship. I would like to express my special appreciation and thanks to my referee Prof. Dr. Bent T. Hansen. I would like to thank him for encouraging my research and for allowing me to grow as an isotope hydrologist. Prof. Dr. Bent T. Hansen and Pia Hansen supported me at anytime in everything, and especially I can't thank you enough for encouraging me throughout this experience. I would like to thank my co-referee Dr. Klaus Wemmer for supporting me at anytime in case of questions.

This thesis was only possible with the help of DGR and TINT staffs who assisted me during fieldwork. I thank Jirateep Yodmao and Monthon Yongprawat who helped me for groundwater sampling and sample analyses. I am grateful to Dr. Helmut Dürrast, Sumrit Chusanathas, Dr. Aranya Fuangswasdi, Dr. Oranuj Lorphensri for the inspiring discussions and their helpful advices. Many thanks to Shada Musallam, Anne Poh and Wiebke Warner, who always assisted me in German and English language.

It was a pleasure to work with a nice team in such a friendly and enjoyable atmosphere as in the department of Isotope Geology in Göttingen. I am also grateful to Brigitte Dietrich, Franziska Wilsky, Nicole Nolte, Sabrina Metje and Dr. Klaus Simon who help me a lot during laboratory work. A very big thank to Dr. Christine Heim who opened my geology world through my first fieldtrip in Äspö.

Many thanks to all of my colleagues, Thai friends in Göttingen and Rucha Helmcke for the wonderful time in Götttingen and for emotional support during the whole time of my thesis.

Finally, I am grateful to my family, they were always there for me. 


\section{PREFACE}

This doctoral thesis comprises the following articles that are either published, or in press as indicated below:

Hengsuwan, M.,Yongprawat, M., Simon, K., Hansen, B. T. (accepted) Isotope- and REE-Characterization of Groundwater Aquifers within the Aquifer Storage and Recovery Programme in Sukhothai (N.-Thailand). Journal of Water Resource and Protection. DOI: 10.4236/jwarp.2016***

Hengsuwan, M., Heim, C., Simon, K., Hansen, B. (2015) Long-term investigation of $\mathrm{Sr}$ - isotope and rare earth element fractionation processes within three major aquifers in the Äspö Hard Rock Laboratory (Sweden), Geomicrobiology Journal, 32:3-4, 243-254.

DOI:10.1080/01490451.2014.962121

Hengsuwan, M., Dürrast, H., Hansen, B. T. (2015) Geochemical characteristics and origin of $\mathrm{CO}_{2}$-rich groundwater in Southern Thailand. Proceedings of the 5th GEOINDO 2015, 23-24 November 2015, Khonkaen, Thailand, full manuscript volume. 5p. 


\section{ABSTRACT}

This $\mathrm{PhD}$ thesis investigates the application of isotope techniques in groundwater aquifers, with the main focus on systematic variations of the Strontium (Sr) isotopes and chemical composition including fractionation patterns of rare earth elements (REE).

This thesis is subdivided into five chapters. After the introduction, in the second chapter (chapter 2), an attempt is made to assess the efficiency of the Aquifer Storage and Recovery Project (ASR) by using isotope tracers, such as strontium and stable isotope and to prove the suitability of natural tracers to follow up the artificial recharge process. The results showed that the change in ${ }^{87} \mathrm{Sr} /{ }^{86} \mathrm{Sr}$ ratios could be observed during an artificial recharge due to the different isotopic fingerprint of surface water and groundwater. However, the flow direction of the injected water cannot be clearly interpreted because of the limited number of monitoring wells, small distance between each monitoring well and the short duration of injection. In chapter 3 , the investigation of variations of the isotopic and chemical composition as well as fractionation patterns of rare earth elements (REE) of three different aquifers at Äspö Hard Rock Laboratory has been carried out over five years. The aims of this study are to identify the possible endmembers of groundwater composition and to increase understanding about groundwater evolution of paleo-groundwater in this area as well as the effect of tunnel building on internal mixing of groundwater and chemical change. The Sr-data and REE patterns show especially the long-term groundwater-rock interaction and $\delta^{18} \mathrm{O}$ values indicate the presence of glacial meltwater in the deep aquifer. Significant chemical changes caused by internal mixing processes or present microbial activity were not observed during the five years of investigation. In chapter 4, we make an effort to clarify the hydrochemical behavior of the $\mathrm{CO}_{2}$-rich groundwaters and identify possible sources of their $\mathrm{CO}_{2}$ in Southern Thailand by analyses of major elements, REE and isotopic composition $\left({ }^{3} \mathrm{H}, \delta^{13} \mathrm{C},{ }^{87} \mathrm{Sr} /{ }^{86} \mathrm{Sr}\right)$. The results show that these $\mathrm{CO}_{2}$-rich groundwaters are characterized by high contents of $\mathrm{HCO}_{3}{ }^{-}, \mathrm{SO}_{4}{ }^{2-}, \mathrm{Cl}^{-}$, Total Dissolved Solid (TDS), $\mathrm{Ca}^{2+}, \mathrm{Mg}^{2+}, \mathrm{K}^{+}, \mathrm{Sr}^{2+}$ and $\mathrm{Ba}^{2+}$. Upper continental crust (UCC) normalized REE patterns show a slight heavy REE (HREE) enrichment with high positive Eu anomalies and they show a specific high ${ }^{87} \mathrm{Sr} /{ }^{86} \mathrm{Sr}$ ratio of 0.726 , The ${ }^{3} \mathrm{H}$ amount indicates that 
$\mathrm{CO}_{2}$-rich groundwaters are submodern groundwater, which were recharged before 1950s; whereas non- $\mathrm{CO}_{2}$-rich groundwaters in the same area show higher amount of ${ }^{3} \mathrm{H}(1.50-1.57$ TU), which indicates mixing of submodern and modern groundwater. While the $\delta^{13} \mathrm{C}$ values indicate a deep seated mantel source for $\mathrm{CO}_{2}$. In the future, the attempt is made to combine isotope techniques and modeling techniques together to optimize isotope data as a powerful forecasting tool for a better groundwater management. 


\section{Table of Contents}

Acknowledgements.

Preface

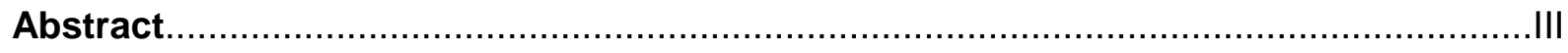

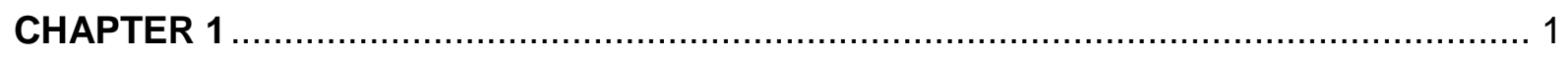

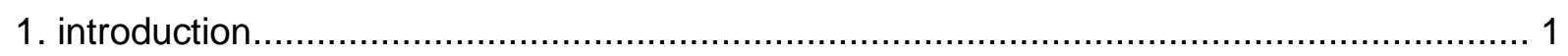

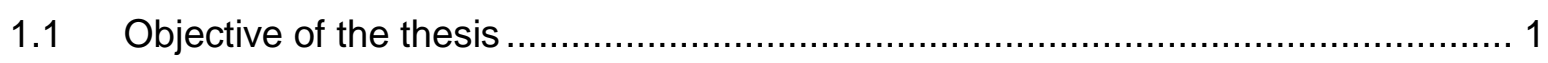

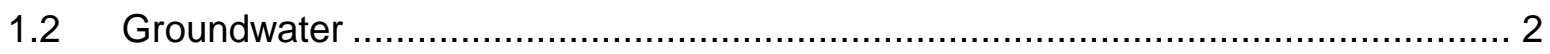

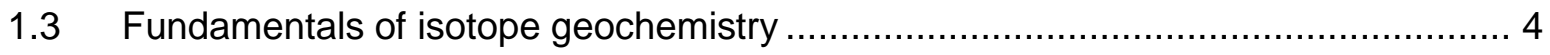

1.3.1 Environmental isotopes in hydrogeology ................................................ 5

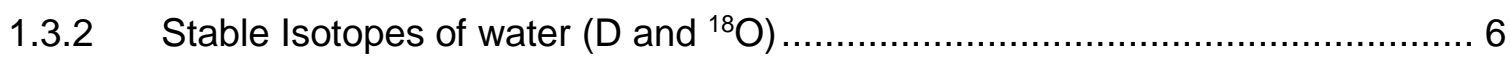

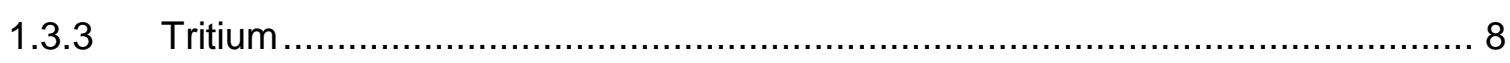

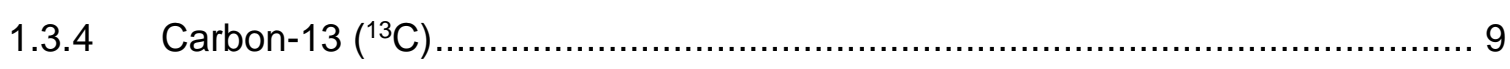

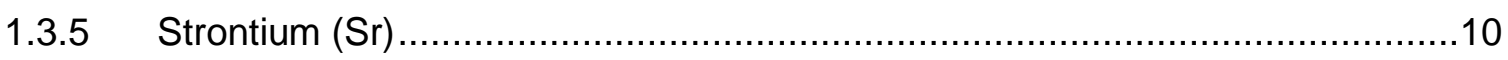

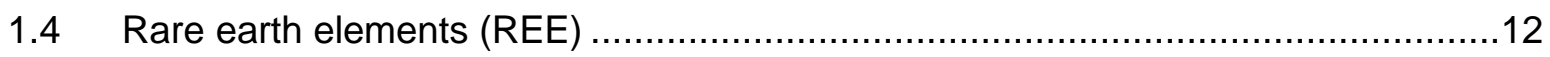

1.5 Management of Aquifer Recharge .............................................................

1.5.1 Aquifer Storage and Recovery (ASR) ................................................ 13

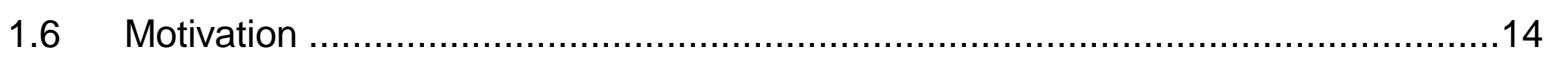

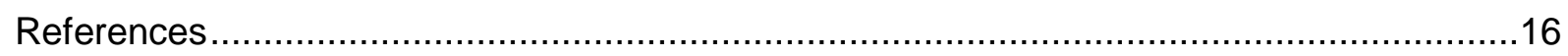

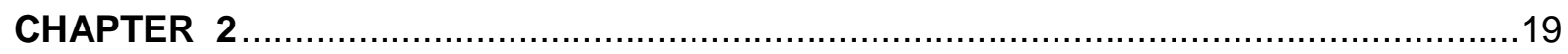

Manuscript I: Isotope- and REE-Characterization of Groundwater Aquifers within the Aquifer Storage and Recovery Program in Sukhothai (N.-Thailand) ................................19

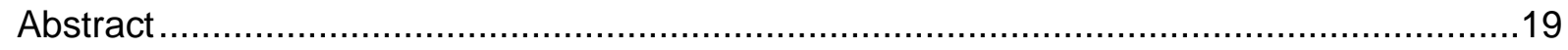

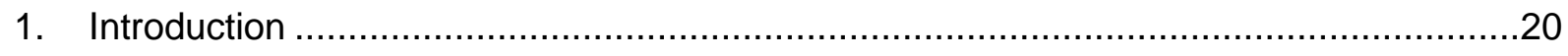

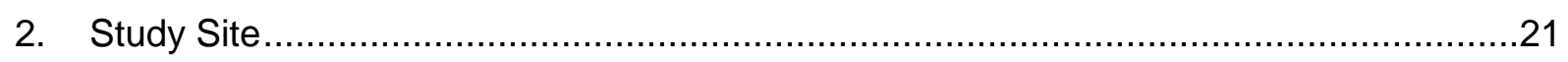

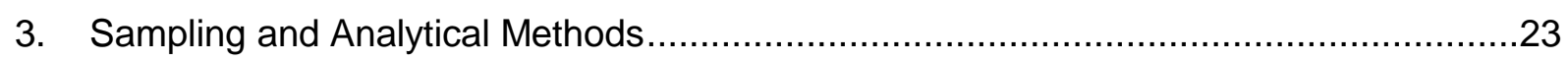

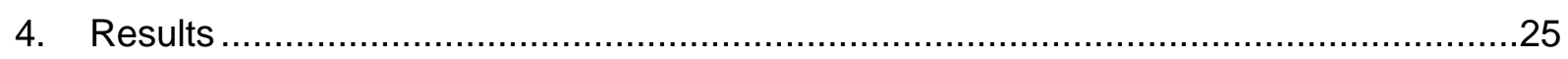

4.1 Initial Long Term ASR Testing by Pump Pressure Method in Year 2012 ..............25

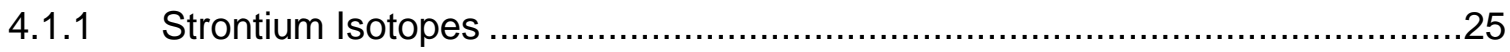

4.1.2 Strontium Isotopes and REE in the deep aquifer after initial long term ASR

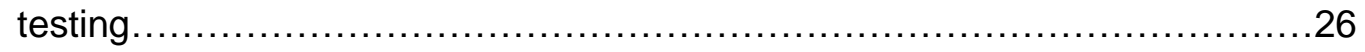

4.2 Long Term ASR Testing by Pump Pressure Method in Year 2013 ........................28

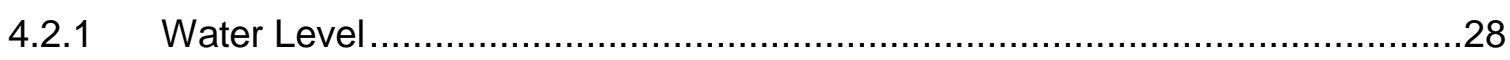

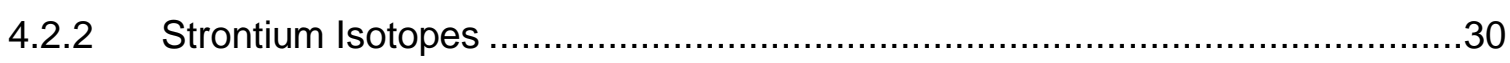

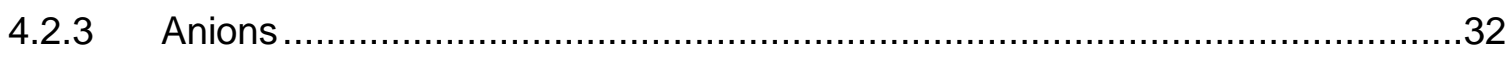

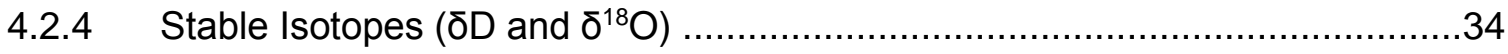




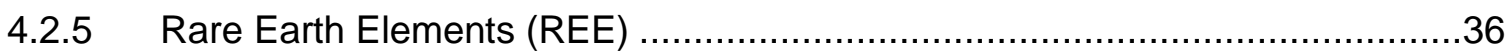

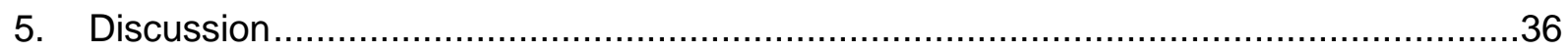

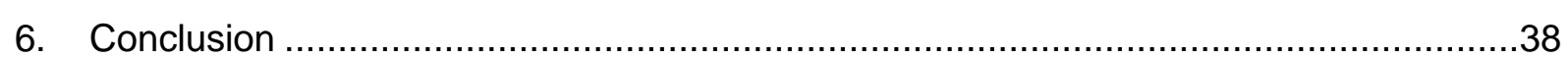

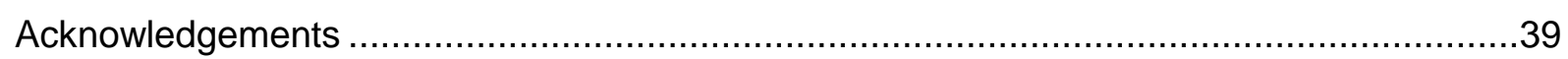

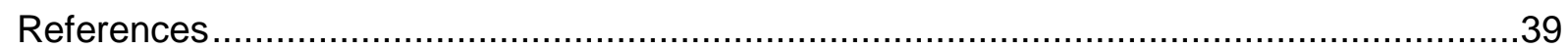

CHAPTER 3 .

Manuscript II: Long-Term Investigation of Sr-Isotope and Rare Earth Element Fractionation Processes within Three Major Aquifers in the Äspö Hard Rock Laboratory (Sweden)

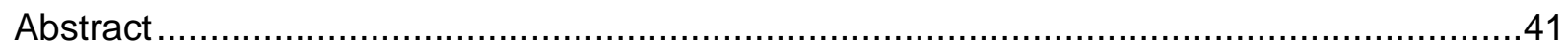

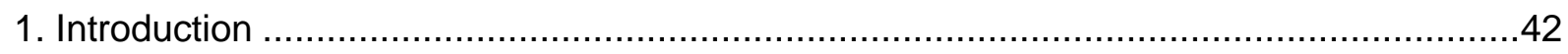

2. Geological Setting and Hydrogeology at the Äspö Site ..........................................43

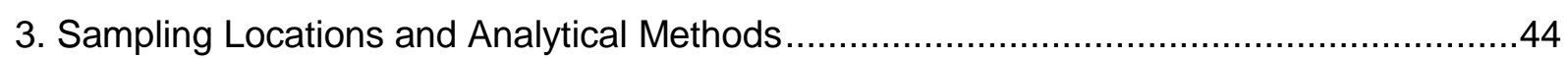

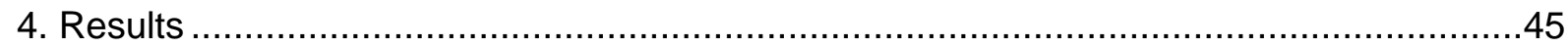

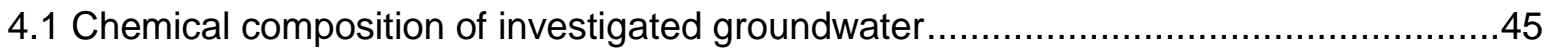

4.2 Isotopic composition of groundwater and host rocks. ............................................46

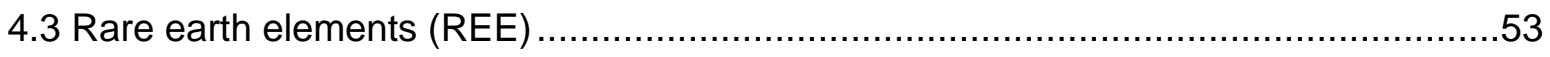

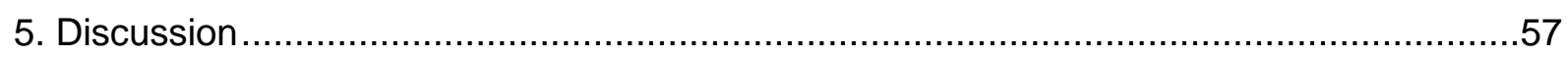

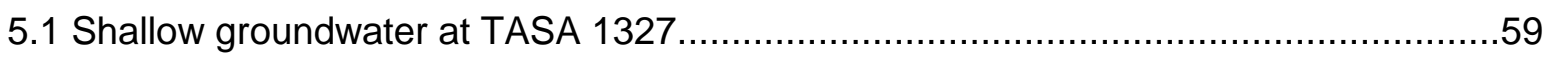

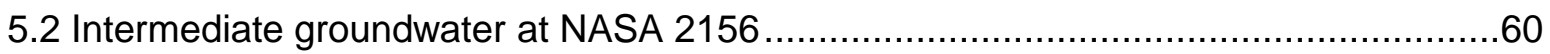

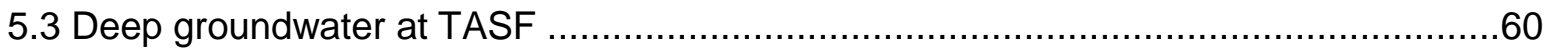

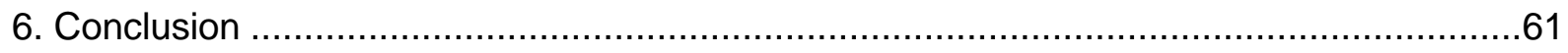

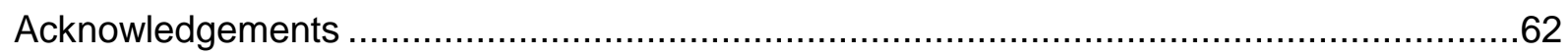

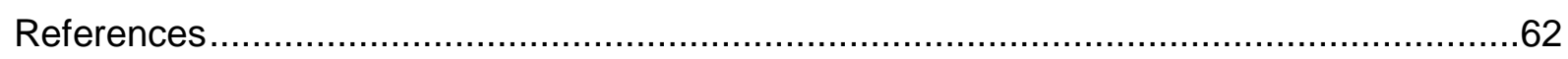

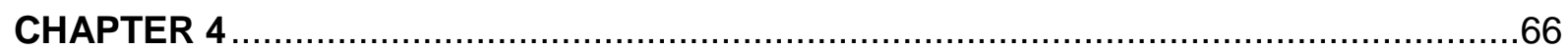

Manuscript III: Geochemical Characteristics and Origin of $\mathrm{CO}_{2}$-rich Groundwater in

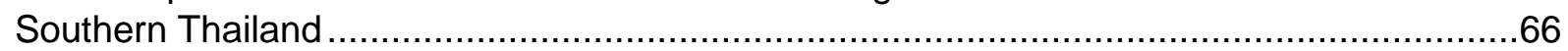

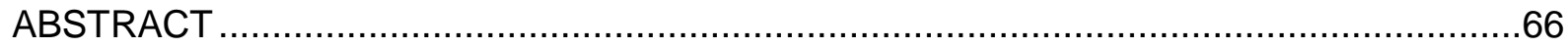

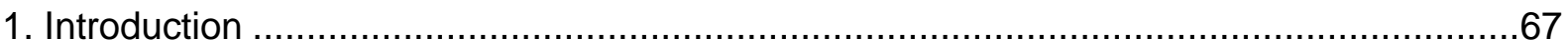

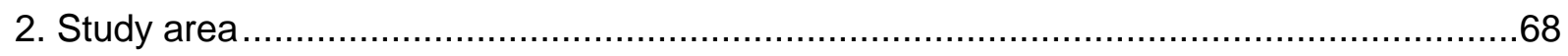

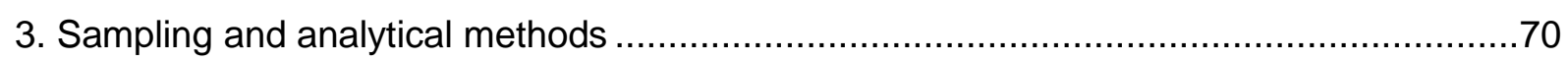

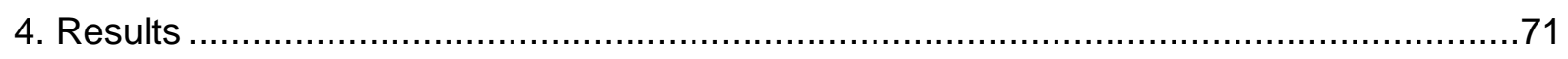

4.1 Chemical composition of investigated groundwater ........................................... 71

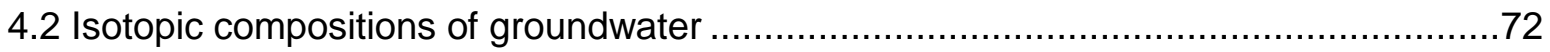

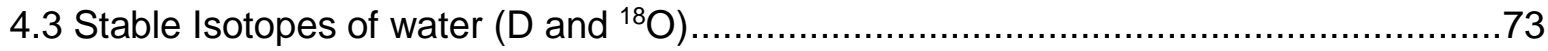

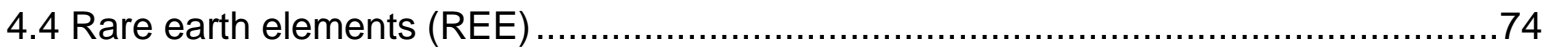

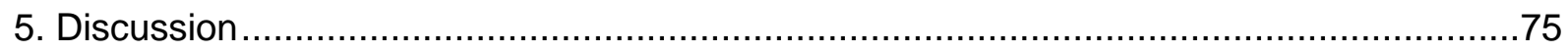

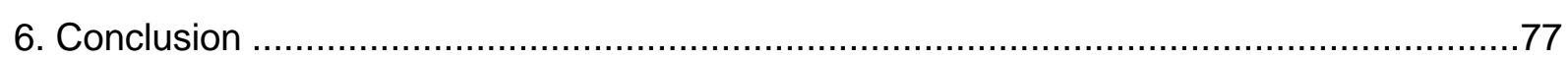

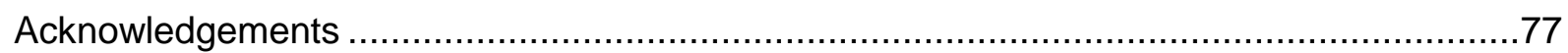


References.

CHAPTER 5

Conclusion .79

Outlook .81

Appendix.

.82 


\section{CHAPTER 1}

\section{INTRODUCTION}

\subsection{Objective of the thesis}

The main goal of the thesis (chapter 2, 3 and 4) is the application of isotope techniques in many aspects of groundwater studies. Emphasis will be placed on systematic variations of the isotopic and chemical composition including fractionation patterns of rare earth elements (REE) to increase the understanding about groundwater evolution, groundwater flow path, origin of groundwater, groundwater age and groundwater-rock interaction. Furthermore, the comprehensive understanding of groundwater systems is essential for a sustainable development of groundwater resources.

A detailed focus of the studies included in the thesis is given below:

\section{Chapter 2:}

Hengsuwan, M., Yongprawat, M., Simon, K., Hansen, B. T. (accepted) Isotope- and REE Characterization of Groundwater Aquifers within the aquifer Storage and Recovery Programme in Sukhothai (N.-Thailand).

Aquifer Storage and Recovery (ASR) project was initiated for solving flood and drought problem in the northern part of Chao Phraya river basin, Thailand. The excessive surface water during rainy season will be injected through recharge wells into underground aquifer. The aim of this study is to assess the efficiency of the ASR process by using isotope tracers, such as strontium and stable isotope and to prove the suitability of natural tracers to follow up the artificial recharge process

\section{Chapter 3:}

Hengsuwan, M., Heim, C., Simon, K., Hansen, B. (2015) Long-term investigation of Sr- isotope and rare earth element fractionation processes within three major aquifers in the Äspö Hard Rock Laboratory (Sweden). 
In this study, systematic variations of the isotopic and chemical composition including fractionation patterns of rare earth elements (REE) of three different aquifers at Äspö Hard Rock Laboratory were investigated over five years to identify the possible end-members of groundwater composition and to increase the understanding about groundwater evolution of paleo-groundwater in this area as well as the effect of tunnel building on internal mixing of groundwater and chemical change.

\section{Chapter 4:}

Hengsuwan, M., Dürrast, H., Hansen, B. T. (2015) Geochemical characteristics and origin of $\mathrm{CO}_{2}$-rich groundwater in Southern Thailand

$\mathrm{CO}_{2}$-rich groundwaters have been found in many parts of the world, including Thailand. However, there are only few academic reports about $\mathrm{CO}_{2}$-rich groundwater in Thailand. In this study, analyses of major element, REE and isotopic composition $\left({ }^{3} \mathrm{H}, \delta^{13} \mathrm{C},{ }^{87} \mathrm{Sr} /{ }^{86} \mathrm{Sr}\right)$ were carried out to clarify the hydrochemical behavior of the $\mathrm{CO}_{2}$-rich groundwaters in this area and to identify possible sources of their $\mathrm{CO}_{2}$.

\section{Chapter 5:}

The general conclusions will be summarized in chapter 5 and an outlook for future perspectives will be given in the last part of the thesis.

Due to formal consistency reasons, the chapters will be slightly changed from the original publication and references for each chapter will be given at the end of each chapter.

\subsection{Groundwater}

Groundwater is the largest component of fresh water in the world, which is accessible for human use. Two thirds of the earth is covered with water, but most of this water is saline and only $3.5 \%$ is fresh water, furthermore, $69 \%$ of this fresh water is locked up in glacial ice. About $30 \%$ of the fresh water (or $0.76 \%$ of the total water on earth) is groundwater. Whereas only $0.26 \%$ of the fresh water is present as surface water in lakes, rivers and reservoirs (Fitts 2013). Groundwater is a part of the global hydrological cycle, which is driven by solar energy (Figure 1). When rain falls, the rainwater infiltrates into the soil or runs off through rivers to the ocean 
and the remainder can evaporate. The groundwater system is dynamic and water moves continuously down gradient from the recharge area through the soil particles and fractured rock beneath the surface to the discharge area, where groundwater enter a lake or stream and becomes surface water. The water bodies will turn into water vapor, condense and fall as precipitation. As water flows into the ground, it begins to record information on the history of its due to occurring chemical processes during moving through the soil as shown in Figure 1. The chemical changes and isotopic variations may be used to identify this evolution and provide information on water flow paths, recharge source and mixing processes in the unsaturated and saturated zone (Herczeg \& Edmunds 2000).

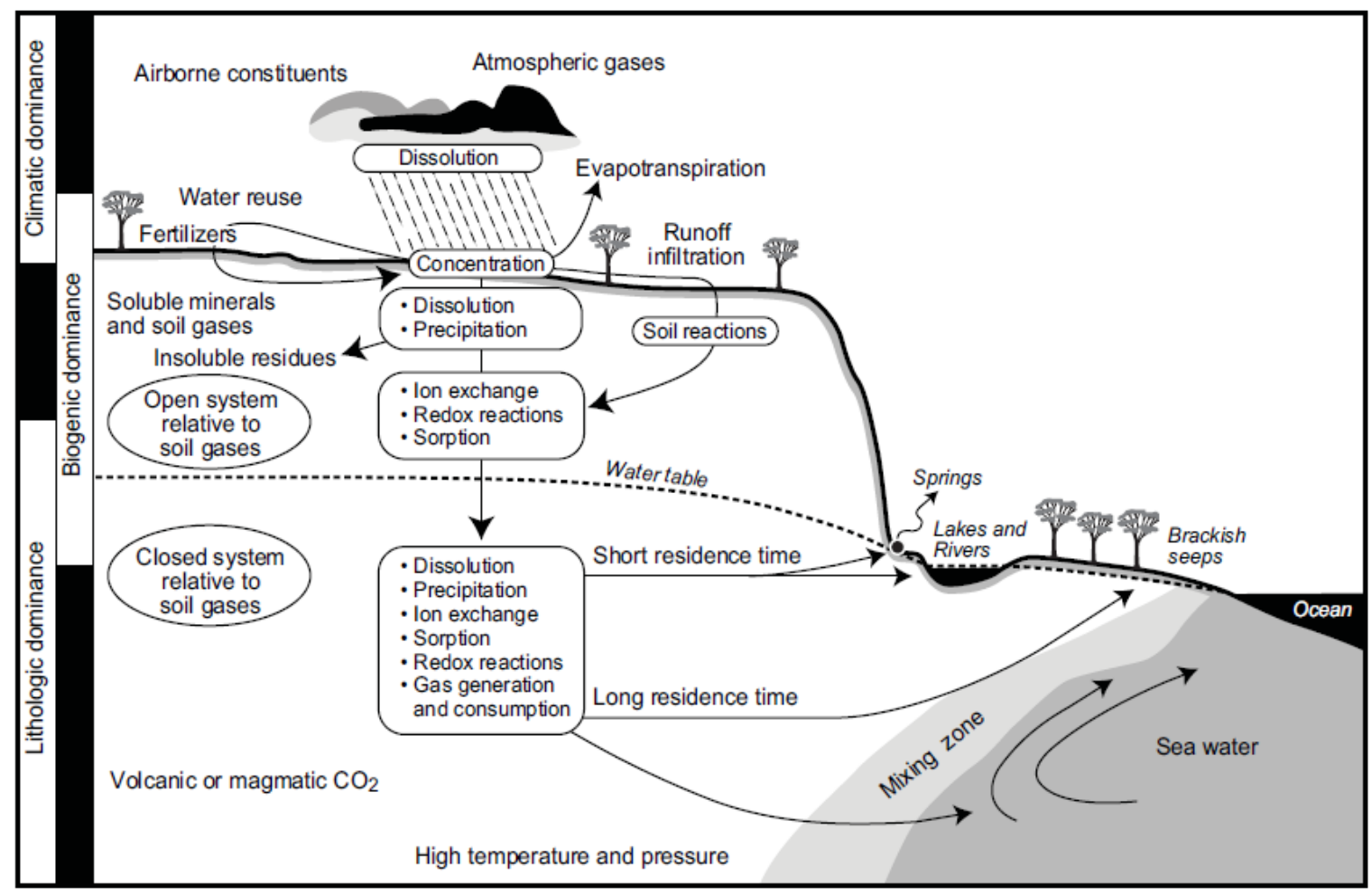

Figure 1. A conceptual diagram of the hydrological cycle incorporating processes affecting the transport and reactions involving major ions (Herczeg \& Edmunds 2000) .

Groundwater is an important source of freshwater throughout the world, which is about 100 time more plentiful than fresh surface water (Fitts 2013). However, due to the accessibility, surface water has been used more than groundwater, but in many parts of the world groundwater is the main source for drinking water, agriculture and industrial use. The overexploitation of groundwater in many parts of the world lead to many problems e.g. rapidly 
declining of groundwater level, lowering of pump sets position causing operation costs, reduction of groundwater yield, land subsidence and sea water intrusion.

\subsection{Fundamentals of isotope geochemistry}

Isotopes are atoms of the same element (same numbers of protons) that have different numbers of neutrons, which lead to different masses in different isotopes of the same element. For example, Deuterium ( $\mathrm{D}$ or ${ }^{2} \mathrm{H}$ ) is one of hydrogen isotopes with one proton and one neutron, whereas Tritium $\left({ }^{3} \mathrm{H}\right)$ is a hydrogen isotope, which has one proton and two neutrons. The number of isotopes in each element can be found in the chart of nuclides, which provides an overview of the existing isotopes (Figure 2). Isotopes of a single element are shown in a horizontal row of nuclide chart. Isotones are nuclides that have the same number of neutron (e.g. ${ }^{88} \mathrm{Sr}$ and ${ }^{87} \mathrm{Rb}$ are isotones). Isobars are nuclides that have the same atomic mass value (a diagonal array in Figure 2, e.g. ${ }^{40} \mathrm{Ca}$ is isobaric with ${ }^{40} \mathrm{~K}$ and ${ }^{40} \mathrm{Ar}$ ).

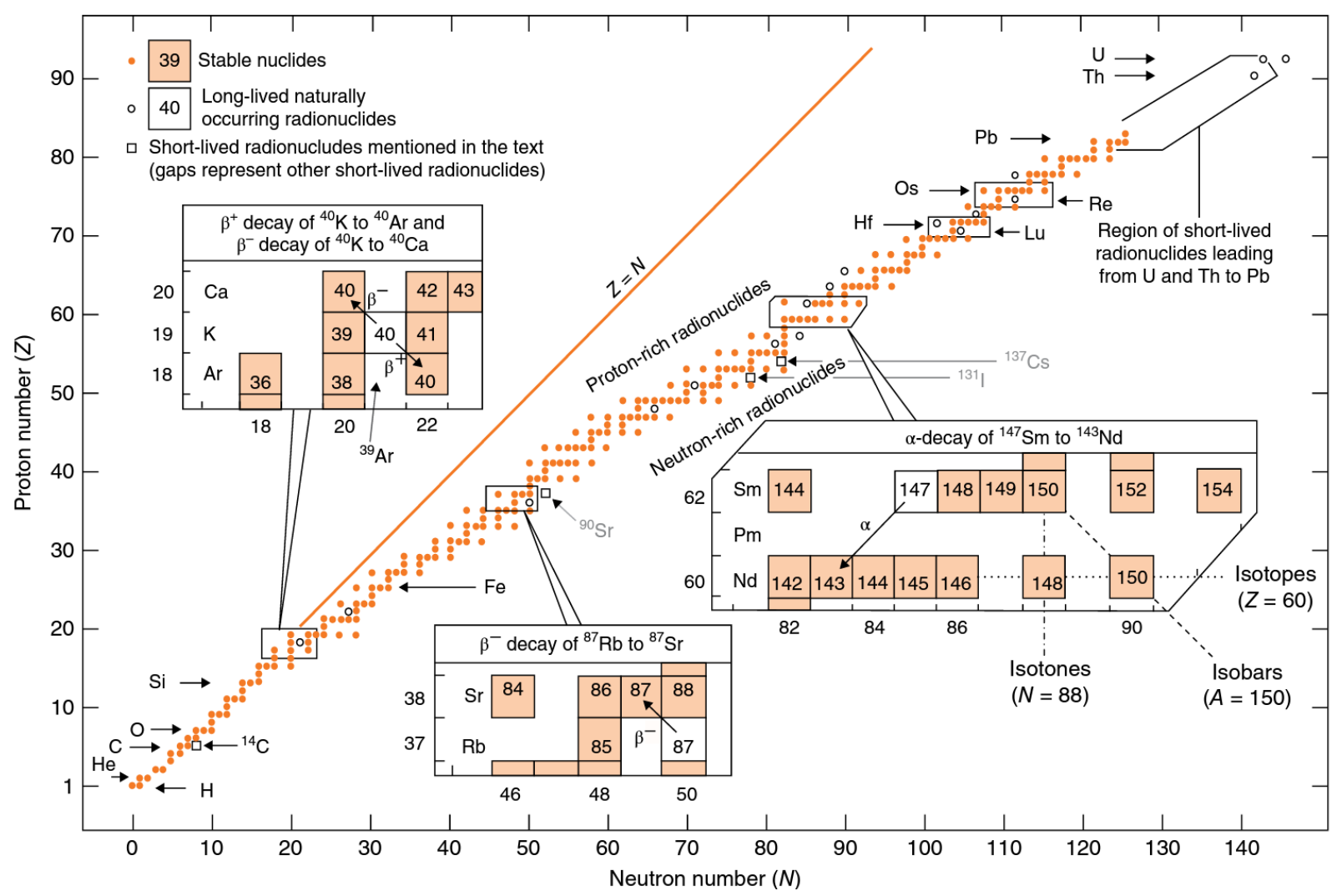

Figure 2. The chart of nuclides (Gill 2015). 


\subsubsection{Environmental isotopes in hydrogeology}

The focus of this dissertation was on application of stable and radioactive environmental isotopes in groundwater studies. Applications of isotopes in groundwater studies are commonly based on concept of "tracing". Environmental tracers are defined as natural or anthropogenic compounds or isotopes that are widely distributed in the near-surface environment of the earth, such that variations in their abundance can be used to determine pathways and timescales of environmental processes (Cook \& Boehlke 2000). Isotope hydrology is a relatively new scientific discipline, which can give a direct insight into the movement of water in hydrological system. Waters, which were recharged at different time and/or different recharge locations normally have distinctive "fingerprints". Compared to most chemical tracers, environmental isotopes are relatively conservative in reaction with material in catchment (Bullen \& Kendall 1998). Isotope techniques are effective tools and can provide important hydrological information for the better management of groundwater resources. Environmental isotopes occur naturally in the atmosphere and the hydrosphere with different concentrations. The most frequently used environmental isotopes are the heavy isotopes of water molecules, hydrogen $\left({ }^{2} \mathrm{H}\right.$ or $\mathrm{D}$ and $\left.{ }^{3} \mathrm{H}\right)$ and oxygen $\left({ }^{18} \mathrm{O}\right)$ as well as carbon $\left({ }^{13} \mathrm{C}\right.$ and $\left.{ }^{14} \mathrm{C}\right)$, which can be found in dissolved inorganic and organic carbon compound. Typical uses of environmental isotopes in hydrology include (Kendall \& Caldwell 1998):

- Identification of streamflow

- Flow paths characterization

- Determination of flow paths and water-budget models developed using hydrometric data

- Studies of weathering reactions and

- Identification of groundwater age, groundwater sources and sources of solutes in contaminated system. 


\subsubsection{Stable Isotopes of water ( $D$ and $\left.{ }^{18} O\right)$}

A water molecule is composed of two hydrogen atoms and one oxygen atom. The element oxygen has three stable isotopes ${ }^{16} \mathrm{O},{ }^{17} \mathrm{O}$ and ${ }^{18} \mathrm{O}$ with abundance of $99.76,0.035$ and $0.2 \%$, respectively (Nier 1950). The concentration of stable isotopes of water is usually measured by isotope ratio mass spectrometer. Water molecule can have an unified atomic mass unit $(\mathrm{u})$ of $18\left(\mathrm{H}_{2} \mathrm{O}\right), 19(\mathrm{HDO}), 20\left(\mathrm{H}_{2}^{18} \mathrm{O}\right)$ or $21\left(\mathrm{HD}^{18} \mathrm{O}\right)$. These isotopes are ideal environmental tracers, because they are components inside water molecules. They have been used in groundwater studies as a complementary tool to answer the questions about water sources and recharge areas (Clark 2015). There are two main physical processes that affect the stable isotope distribution through the hydrological cycle include evaporation and condensation. During evaporation the lighter molecules of hydrogen and oxygen (e.g. $\mathrm{H}_{2}{ }^{16} \mathrm{O}$ ) go into vapor preferentially. Therefore, the vapor that evaporates from ocean is isotopically depleted approximately $13 \%$ in ${ }^{18} \mathrm{O}$ (Figure 3 ). Whereas during condensation the heavier isotopes of water molecules will condense preferentially and the residual vapor will be more and more depleted in $\mathrm{D}$ and ${ }^{18} \mathrm{O}$ (Deodhar et al. 2014).

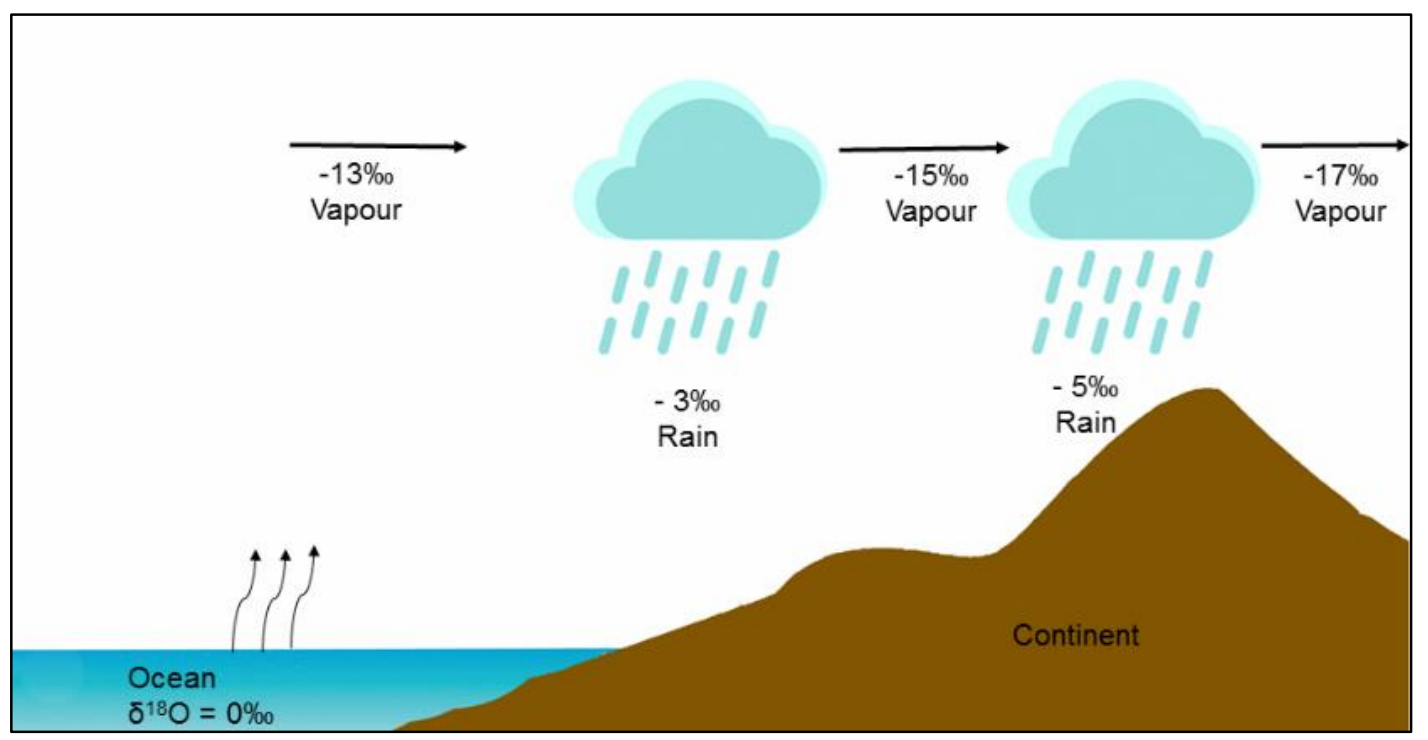

Figure 3. The evolution in ${ }^{18} \mathrm{O}$ content of precipitation (modified after Hoefs 1997). 


\section{Global meteoric water line}

Craig (1961) showed the strong correlation between $\mathrm{D}$ and ${ }^{18} \mathrm{O}$ in global precipitation.

Globally, the isotopic composition of precipitation $\left(\delta^{18} \mathrm{O}\right.$ and $\left.\delta \mathrm{D}\right)$ lies along the Global Meteoric Water Line (GMWL) as follows:

$$
\delta \mathrm{D}=8 \delta^{18} \mathrm{O}+10 \%
$$

This relationship for $D$ and ${ }^{18} \mathrm{O}$ isotopes is the result of differences in their equilibrium fractionation factors. The slope of GMWL shows this ratio, which is eight time greater for oxygen than hydrogen (Figure 4).

The fractionation of stable isotopes in the water molecules can be controlled by many factors include following:

- Temperature effect: Precipitation is depleted in heavier isotopes with decreasing temperature.

- Latitude effect: The isotopic composition of precipitation gets lighter with increasing latitude.

- Continental effect: The isotopic composition of precipitation gets lighter toward continental interior.

- Altitude effect: The isotopic composition of precipitation gets lighter with elevation.

- Rainout effect: Initial precipitation is enriched in heavier isotopes compared to later precipitation.

- Seasonal effect: Winter precipitation is depleted in heavier isotopes with respect to summer precipitation (Clark 2015). 


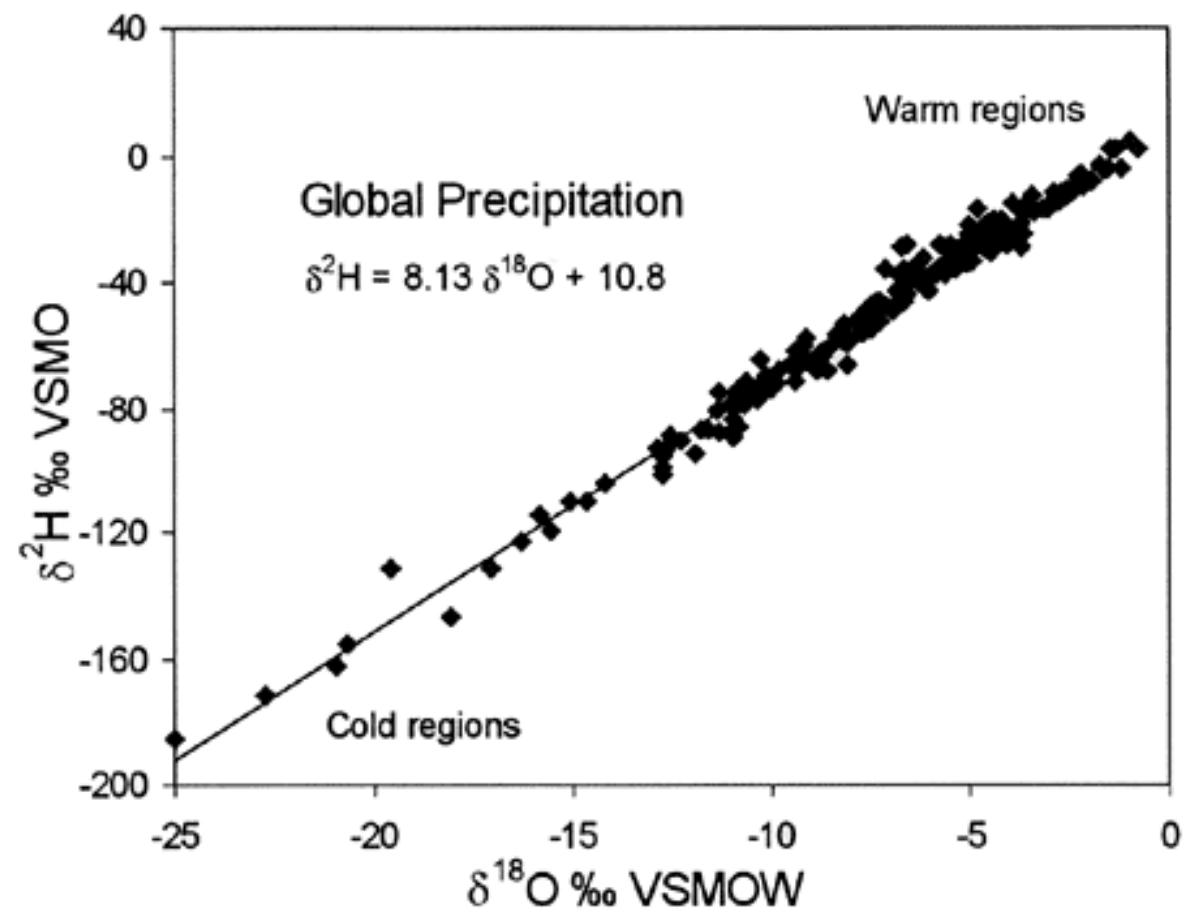

Figure 4. The $\delta \mathrm{D}$ and $\delta^{18} \mathrm{O}$ correlation for global precipitation (Craig 1961).

In chapter 3, D and ${ }^{18} \mathrm{O}$ were used to identify different groundwater sources in three aquifers at Äspö Hard Rock Laboratory, Sweden. In chapter 4, D and ${ }^{18} \mathrm{O}$ were used to distinguish groundwater sources in $\mathrm{CO}_{2}$-rich groundwater and non- $\mathrm{CO}_{2}$-rich groundwater in Songkhla province, Thailand. As shown in chapter 3 and chapter $\mathbf{4}$, stable isotopes of water are an appropriate tool for groundwater provenance studies. In chapter 2, the investigation of D and ${ }^{18} \mathrm{O}$ has been carried to trace groundwater flow during artificial recharge in Sukhothai province, Thailand.

\subsubsection{Tritium}

Tritium $\left({ }^{3} \mathrm{H}\right)$ is a radioisotope of hydrogen with a half-life of 12.43 years that occurs naturally on the surface of the Earth due to a continuous production by a nuclear production in the atmosphere by cosmic ray interaction with $\mathrm{N}_{2}$ :

$$
{ }_{7}^{14} \mathrm{~N}+{ }_{0}^{1} \mathrm{n} \rightarrow{ }_{1}^{3} \mathrm{H}+{ }_{6}^{12} \mathrm{C} .
$$


Tritium in the atmosphere can be a component in water molecules either by direct oxidation or by exchange with $\mathrm{H}$ stable isotope $\left({ }^{1} \mathrm{H}\right.$ or $\left.\mathrm{D}\right)$ to form tritiated water $\left({ }^{3} \mathrm{HHO}\right)$ and enters the hydrological cycle (Faure 2005). During the late 1950s and early 1960s large amount of ${ }^{3} \mathrm{H}$ was released to the atmosphere due to thermonuclear reaction during atmospheric nuclear bomb tests. Either natural or anthropogenic tritium enters the hydrological cycle via precipitation as shown in Figure $5 .{ }^{3} \mathrm{H}$ concentrations are generally given as TU (Tritium Unit), equivalent to one molecule of ${ }^{3} \mathrm{H}$ per $10^{18}$ molecules of ${ }^{1} \mathrm{H}$. The detection of tritium in groundwater is an indication of recent groundwater recharge. In chapter $\mathbf{3}$ and chapter $\mathbf{4}$, tritium concentration was used to estimate the age or residence time of groundwater.

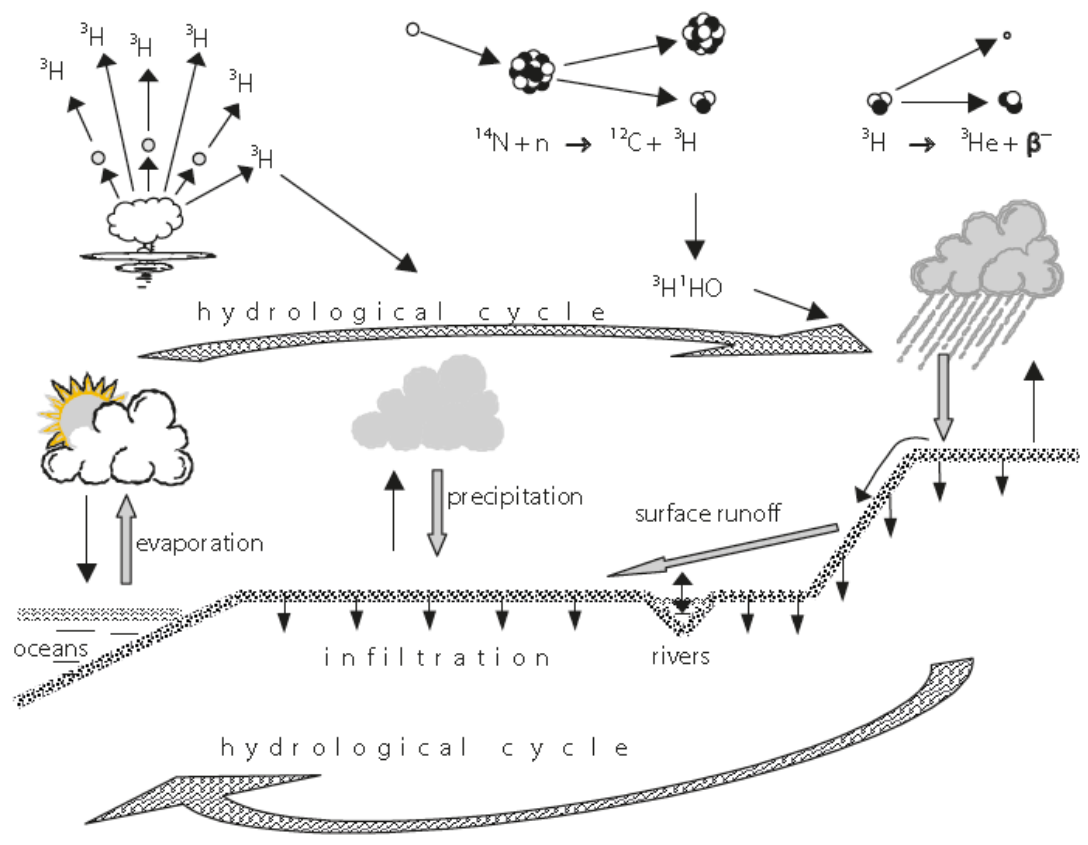

Figure 5. Origin and distribution of ${ }^{3} \mathrm{H}$ in nature (Mook 2001).

\subsubsection{Carbon-13 $\left({ }^{13} \mathrm{C}\right)$}

Carbon (C) is an important element on the earth. It involves in the food chain on the earth and biogeochemical processes. Carbon has two stable isotopes, ${ }^{12} \mathrm{C}$ and ${ }^{13} \mathrm{C}$ with an abundance of $98.89 \%$ and $1.11 \%$, respectively and one radioactive ${ }^{14} \mathrm{C}$, which has a half-life of 5730 years (e.g. Bullen \& Kendall 1998). Carbon isotopes have been used widely to trace the carbon cycle globally and in groundwater. The differences in ${ }^{13} \mathrm{C} /{ }^{12} \mathrm{C}$ ratios among minerals, gases, plants 
and waters are the result of isotopic fractionation in various biogeochemical processes. The ${ }^{13} \mathrm{C} /{ }^{12} \mathrm{C}$ ratio is generally reported as the difference in parts per thousand (\%o) from a standard:

$$
\delta^{13} \mathrm{C}(\%)=\left[\left({ }^{13} \mathrm{C} /{ }^{12} \mathrm{C}\right)_{\text {sample }} /\left({ }^{13} \mathrm{C} /{ }^{12} \mathrm{C}\right)_{\text {standard }}-1\right]^{\star} 1000
$$

where the standard is PDB (PeeDee Belemnite), a Cretaceous mollusk. Photosynthesis is a highly fractionation process that discriminates against ${ }^{13} \mathrm{C}$ during transformation of $\mathrm{CO}_{2}$ to carbohydrate (Clark 2015). Different carbon-bearing materials can have distinct and characteristic ${ }^{13} \mathrm{C}$ values. Atmospheric $\mathrm{CO}_{2}$ has typically $\delta^{13} \mathrm{C}$ value of about $-8 \%$. Plants convert atmospheric $\mathrm{CO}_{2}$ in the difference photosynthesis reaction have different $\delta^{13} \mathrm{C}$ values; $C_{3}$ plants have $\delta^{13} \mathrm{C}$ values of about $-27 \%$, whereas $C_{4}$ plants have $\delta^{13} \mathrm{C}$ value between about $-10 \%$ and $-14 \%$. Carbonate rocks have $\delta^{13} \mathrm{C}$ values of $0 \%$ (e.g. Clark 2015). $\delta^{13} \mathrm{C}$ values of dissolved inorganic carbon (DIC) range generally between $-5 \%$ and $-25 \%$ o depending on the reactions that produce DIC, for example:

1. $\delta^{13} \mathrm{C}$ value of DIC by weathering of carbonate minerals by acidic rain or strong acid will be identical to that in the reacting carbonate.

2. $\delta^{13} \mathrm{C}$ value of DIC by weathering of silicate minerals by carbonic acid produced from the dissolution of biogenic soil $\mathrm{CO}_{2}$ be identical to carbonic acid.

3. $\delta^{13} \mathrm{C}$ value of DIC by weathering of carbonate mineral by carbonate acid will intermediate between the composition of carbonate mineral and carbonic acid (Bullen \& Kendall 1998).

Carbon isotopes can be used to explain the biogeochemical reactions in catchments, the geochemical evolution of groundwater and also be useful tracers of the seasonal contributions of different hydrologic flow paths to streamflow and for quantifying soil water and groundwater contributions to streamflow. Moreover, the $\delta^{13} \mathrm{C}$ values of organic materials can provide useful information about sources of contaminants.

\subsubsection{Strontium $(\mathrm{Sr})$}

Strontium (Sr) has four natural occurring stable isotopes, namely ${ }^{84} \mathrm{Sr},{ }^{86} \mathrm{Sr},{ }^{87} \mathrm{Sr},{ }^{88} \mathrm{Sr}$. Their abundances are approximately $0.56 \%, 9.87 \%, 7.04 \%$ and $82.53 \%$, respectively (e.g. Faure 
2005). Sr is a divalent alkaline earth element $\left(\mathrm{Sr}^{2+}\right)$, which can substitute for $\mathrm{Ca}^{2+}$ in calcium rock-forming minerals e.g. carbonates, sulfates and feldspar. However, the abundances of ${ }^{87} \mathrm{Sr}$ are variable based on the Rubidium $(\mathrm{Rb})$ content of the rock. $\mathrm{Rb}$ is an alkali element, which can substitute for Potassium $(\mathrm{K})$ in $\mathrm{K}$-bearing rocks. ${ }^{87} \mathrm{Rb}$ is a radioisotope, which has a half-life of 48.8 billion years and decays to ${ }^{87} \mathrm{Sr}$ (e.g. Neumann \& Huster 1974). Therefore, the distinctly different ${ }^{87} \mathrm{Sr} /{ }^{86} \mathrm{Sr}$ values are a result of different initial ${ }^{87} \mathrm{Sr} /{ }^{86} \mathrm{Sr}$ value, initial $\mathrm{Rb} / \mathrm{Sr}$ value and age (Faure 2005).

The initial ${ }^{87} \mathrm{Sr} /{ }^{86} \mathrm{Sr}$ ratio is 0.69908 , which is known as BABI (basaltic achondrite best initial) was determined by studies of achondrite meteorites assuming they represent the ${ }^{87} \mathrm{Sr} /{ }^{86} \mathrm{Sr}$ ratio at the time of nucleosynthesis. The decay of $\mathrm{Rb}$ caused the increasing ${ }^{87} \mathrm{Sr} /{ }^{86} \mathrm{Sr}$ ratio over the life of the earth. The seawater ${ }^{87} \mathrm{Sr} /{ }^{86} \mathrm{Sr}$ curve through Phanerozoic time (Veizer 1989) provide an essential information for tracing $\mathrm{Sr}$ in groundwater. ${ }^{87} \mathrm{Sr} /{ }^{86} \mathrm{Sr}$ ratio in marine carbonates is about 0.7087 , while the ratio in modern seawater is about 0.709 . In crystalline terrains ${ }^{87} \mathrm{Sr} /{ }^{86} \mathrm{Sr}$ ratios are typically higher than 0.710 . Hence, the ${ }^{87} \mathrm{Sr} /{ }^{86} \mathrm{Sr}$ ratio is an appropriate indicator for the terrain, through which groundwater has been recharged and weathering took place (Clark 2015). The ${ }^{87} \mathrm{Sr} /{ }^{86} \mathrm{Sr}$ ratio in groundwaters have been used to identified distinct groundwater sources. The ${ }^{87} \mathrm{Sr} /{ }^{86} \mathrm{Sr}$ ratio indicates the source of strontium, which is normally related to the weathering sources. Moreover, the ${ }^{87} \mathrm{Sr} /{ }^{86} \mathrm{Sr}$ ratio can be used to identify mixing sources and groundwater flow paths (Frost \& Toner 2004; Naftz et al. 1997; Peterman et al. 2012).

\section{Sr-isotope analysis}

The chemical part of the isotope analysis is divided into three following procedures:

a) isotope dilution: $10 \mathrm{ml}$ of water sample is spiked with 1 small drop of $\mathrm{Rb} / \mathrm{Sr}$-Spike that contains a known amount of isotopes (\#Rb-Sr-17: ${ }^{84} \mathrm{Sr}=0.0163032 \mu \mathrm{mol} / \mathrm{g},{ }^{86} \mathrm{Sr}=$ $7.073677 \times 10^{-4} \mu \mathrm{mol} / \mathrm{g},{ }^{87} \mathrm{Sr}=3.23604 \times 10^{-4} \mu \mathrm{mol} / \mathrm{g},{ }^{88} \mathrm{Sr}=2.82876 \times 10^{-3} \mu \mathrm{mol} / \mathrm{g},{ }^{85} \mathrm{Rb}=$ $\left.3.949685 \times 10^{-3} \mu \mathrm{mol} / \mathrm{g},{ }^{87} \mathrm{Rb}=0.193536 \mu \mathrm{mol} / \mathrm{g}\right)$. 
b) chemical decomposition: the water-spike solution was evaporated at $80^{\circ} \mathrm{C}$. The residue is warmed with $5 \mathrm{ml} \mathrm{HCl}(6 \mathrm{~N})$ at $120^{\circ} \mathrm{C}$ for $24 \mathrm{~h}$ and afterwards evaporated. The second residue is taken with $0.5 \mathrm{ml} \mathrm{HCl}(3 \mathrm{~N})$ and must be centrifuged for $10 \mathrm{~min}$ at $9000 \mathrm{rpm}$.

c) columnar elution: A $3 \mathrm{~cm}$ long Micro Bio-Spin ${ }^{\mathrm{TM}}$ column ( $\mathrm{Sr}$ specific resin) was washed with $350 \mu \mathrm{l}$ distilled water ( 6 times) and $350 \mu \mathrm{l} 3 \mathrm{~N} \mathrm{HNO}_{3}$ (6 times). After that $350 \mu \mathrm{l}$ of the centrifuged solution is rinsed into the micro column, washed with $350 \mu \mathrm{l} 3 \mathrm{~N} \mathrm{HNO}_{3}$ (6 times) and $350 \mu \mathrm{l}$ distilled water (6 times). The obtained residue was evaporated at $80^{\circ} \mathrm{C}$.

After the chemical separation, the isotopic measurements are performed with a Thermal lonisation Mass Spectrometer (TIMS), using a Finnigan TRITON ${ }^{\circledR}$. One $\mu$ l of this solution is loaded on a Rhenium double-filaments, heated with $0.8 \mathrm{~A}$ to evaporate the solvent and mounted on the turret. For ionisation the two filaments were heated up to the required temperature. When the signal has reached $1 \mathrm{~V}$ and was constant or increasing, the measurement can be started. During the entire period of this work a value of $0.710267 \pm$ $0.000044(2 \mathrm{~s})$ for the NBS $987(n=22)$ was observed. Instrumental mass-fractionation was corrected with a ${ }^{88} \mathrm{Sr} /{ }^{86} \mathrm{Sr}$ value of 0.1194 using exponential law.

\subsection{Rare earth elements (REE)}

The rare earth elements (REE) or lanthanide elements are a group of 14 elements with similar ionic radii and valence state. The crystal ionic radius decreases from La (1.016 $\AA$ ) to Lu $(0.85$ $\AA$ ) and they have a $3^{+}$valence within the siliciclastic fraction of sediment and sedimentary rocks (Piper \& Bau 2013). They behave chemically coherent and sensitive to changes in $\mathrm{pH}$, redox condition, and adsorption/desorption reactions. These characteristics make REE attractive tools for hydrological applications such as water-rock interaction and groundwater mixing member. Difference processes occurring within a groundwater system can result in the changes in expected REE patterns. The concentrations of REE in this study were were analysed by ICPMS on a PerkinElmer DRC II (Sciex, Canada) at the department of 
Geochemistry (Geoscience Center Göttingen). The obtained REE data were normalized with corresponding international standards.

\subsection{Management of Aquifer Recharge}

Managed aquifer recharge (MAR) programs have been used worldwide to recharge overused aquifers with surface water as an important part of adaptation and sustainability strategies in the face of climate change in many continents including Asia, Europe, America and Africa (Asano 1985; Knorr \& Cliett 1985; Gonzalez et al. 2014; Sheng 2014). An international attempt, "the first international symposium on artificial recharge of groundwater" was organized by American Society of Civil Engineers (ASCE) in August 1988 in Anaheim, California, U.S. (Johnson and Finlayson 1988). The aims of the conferences are to expand water resources and improve water quality in ways that are appropriate, environmentally sustainable, technically viable, economical, and socially desirable (IAH 2016). The $9^{\text {th }}$ International Symposium on managed aquifer recharge (ISMAR9) will be the latest of a series of international symposia and will be held in summer 2016 in Mexico, focusing on solutions to sustainable water management subject to scarcity and climate change.

\subsubsection{Aquifer Storage and Recovery (ASR)}

ASR belong to a type of MAR methods, in which available or excess water will be stored in an aquifer through injection wells and will be recovered when needed. ASR systems are known to be operating in the United States, United Kingdom, Canada, Australia, South Africa and Israel. ASR programs are developing in several other countries, including the Netherlands, New Zealand, Taiwan, Kuwait and Thailand (Pyne 1995; Bouwer 2002; Zuubier et al. 2014; asrforum 2016; United States Environmental Protection Agency 2016). In Thailand, the artificial recharge test was performed first time in 1973 for mitigation of land subsidence in the Bangkok area. The main problems, which occurred during the test were clogging and outbreaks of injected water ca $10 \mathrm{~m}$ away from the recharge well (Phien-wej et al. 1998). In 2008, the Department of Groundwater Resources started to design and construct an ASR site to solve the drought problem in the Upper Chao Phraya River Basin in Sukhothai Province. 
After the construction of the ASR site was completed, a two year pilot ASR project has been started in year 2012. Many studies about hydrological parameters including groundwater flow modeling have been carried out in this area (Putthividha and Koonthanakulvong 2011; Kosasaeng and Kayankarnnavy 2013; Lertsirivorakul and Schulmeister 2014; Bral et al. 2015; Mungkang et al. 2015). The results show that the regional hydraulic gradient ist northwest to southeast direction following the topographic gradient. In addition, a conservative tracing element can be used to monitor the injected water during injection and recovery. Chloride is the most commonly used as a conservative tracer of groundwater and recharge water mixing because it is occurring naturally and unreactive (Ball \& Trudgill 1977). Mungkang 2015 also used Chloride to establish a groundwater flow model of large-scale ASR project in Sukhothai province. In chapter 2, Chloride has been used as to monitor the ASR process within ASR site. Moreover, chapter 2 will test the hypothesis that rare earth elements and isotopic compositions including stable isotopes of water and strontium isotopes can be used as a suitable tracer to evaluate the movement of recharge water and the efficiency of the ASR project.

\subsection{Motivation}

Water is one of fundamental requisites, which is needed in all aspects of life. Groundwater, the largest reservoir of freshwater accessible for human use, becomes a more and more important freshwater source on earth because of the rapid rate of population growth, which results in an increasing in demand for water. The use of groundwater has been widespread in food production processes, agriculture and industries. Groundwater is widely used because it is relatively easy and cheap to use, clean by natural infiltration, easy to develop (individuals can construct and operate their own supply). In many parts of the word, groundwater levels are rapidly decreasing as groundwater abstraction far exceeds natural recharge. In Thailand a number of consequences caused by over-exploitation of groundwater have been found, which are summarized here. 
- Declining groundwater level and decreasing in spring discharge from the groundwater system: Most aquifers show a decreasing of water level and extended water level decline can cause the drying up of the wells. Every year, especially in dry season, there are farmers, who died from lack of oxygen during trying to deepen their dug wells in order to increase the yield and the efficiencies of the wells.

- Land subsidence: Land subsidence from over pumping of groundwater has been affecting Bangkok since 1980 with a rate as high as $120 \mathrm{~mm} /$ year (Phien-wej et al. 2006). Land subsidence in Bangkok has many impacts on the city, e.g. flooding problem and damage of infrastructure.

- Change in flow pattern leading to saline intrusion: Excessive groundwater abstraction can disturb the hydraulic gradients of groundwater. Saline water can be induced into the groundwater system. The over exploitation of groundwater resulted in depression of water level by as much as $65 \mathrm{~m}$ (Phien-wej et al. 2006) and increases in salinity.

In many parts of the world, a lot of research and development in the field of isotope hydrology has been conducted to manage groundwater resources (Verhagen 2003). Isotope techniques have been used to estimate groundwater ages, indicate the vulnerability of groundwater, determine the recharge location (origin of groundwater), identified/quantified the mixing of different groundwater types and evaluate contaminant degradation rates in groundwater systems (Naftz et al. 1997; Frost \& Toner 2004; Peterman et al. 2012). Unfortunately, the application of isotope techniques on groundwater studies in Thailand is quite few due to the limited specialist in this field and limited research subsidy. Therefore, the author tried to use different isotope techniques and chemical analyses to answer the questions in groundwater studies in many perspectives e.g. where the groundwater came from? How old is this groundwater? Where will groundwater flow? What was mixed in groundwater? In chapter 2 the flow path of groundwater during artificial recharge has been investigated by using isotope techniques and chemical components. The emphasis was placed on strontium isotopes, to see how the injected water moves during artificial recharge. Strontium isotopes have been used in water mixing studies many years (Brinck \& Frost 2007). ${ }^{87} \mathrm{Sr} /{ }^{86} \mathrm{Sr}$ ratios in 
groundwaters have been used to fingerprint distinct groundwater sources. They are sensitive indicators and their ratios do not change with evaporation. This study was the first attempt in Thailand to track the injected water during the artificial recharge process by using strontium isotopes. Although it was a pilot project in small scale, the result of this investigation can be very useful and applied for the bigger scale projects in the future. These could be artificial recharge in Bangkok area in order to slow the water level depression and therefore the land subsidence. For the estimation of saline intrusion into the aquifer and for identification of contaminant sources. All processes which are important for the sustainable management either in quantity or in quality of groundwater resources.

\section{REFERENCES}

Asano T. 1985. Overview: Artificial recharge of groundwater. In: Asano T, Editor. Artificial Recharge of Groundwater. Butterworth Publishers, Stoneham, MA. P 3-20.

ASR Forum. 2016. Where is ASR. http://www.asrforum.com/Where-are-ASR-Wells.html (12.04.2016).

Ball $\mathrm{J}$ and Trudgill S. 1997. Potentials and Limitations in Using Geochemical Tracers, in Proceedings of the Rabat symposium, Morocco, May 1997, International. Assoc. Hydrological Sciences 244: 185-194.

Bral K, Tangsutthinon T and Chusanathas S. 2015. Demonstration Program to Mitigate and Flooding in the Northern Part of the Chao Phraya River Basin, Thailan: Using ASR Methods-Part 2. In the Proceeding of $5^{\text {th }}$ Geoindo, Khonkaen, Thailand.

Brinck EL and Frost CD. 2007. Detecting infiltration and impacts of introduced water using strontium isotopes. Ground Water 45(5): 554-568.

Bouwer H. 2002. Artificial recharge of groundwater: hydrogeology and engineering Hydrogeol J 10 (1): 121-142.

Bullen TD and Kendall C. 1998. Tracing of weathering reactions and water flowpath: A multiisotope approach. Kendall C and McDonnell JJ., Editors. Isotope tracers in catchment hydrology. Elsevier: Amsterdam. 839 p.

Clark ID. 2015. Groundwater geochemistry and isotope. CRC Press. 438 p.

Craig H. 1961. Isotopic variations in meteoric waters. Science 133: 1702-1703.

Cook PG and Boehlke JK. 2000. Determining timescales for groundwater flow and solute transport. In: Cook and Herczeg AL, Editors. Environmental tracers in subsurface hydrology. Kluwer Academic Publishers. P 1-30.

Deodhar AS, Ansari A, Sharma S, Jacob N, Kumar US, Singh G. 2014. Isotope Techniques 
for Water Resources Management 337: 29-35.

Faure G, Mensing, TM. 2005. Isotope Principle and Applications $3^{\text {rd }}$ Ed. Hoboken, New Jersey, John Wiley \& Sons, Inc. 897 p.

Fitts C. 2013. Groundwater science, $2^{\text {nd }}$ Edition, Academic Press. 672 p.

Frost CD and Toner RN. 2004. Strontium Isotopic Identification of Water-Rock Interaction and Ground Water Mixing. Groundwater 42(3): 418-432.

Gill R. 2015. Chemical fundamentals of geology and environmental geoscience. $3^{\text {rd }}$ Edition, Wiley-Blackwell. 267 p.

Gonzales D, Page D Vandezalm J, Dillon P. 2015. Setting water quality trigger levels for the operation and management of a MAR system in Parafield, South Australia. Journal of Hydrologic Engineering 20(3).

Herczeg AL and Edmunds WM. 2000. Inorganic ions as tracers. in: Cook and Herczeg AL, Editors. Environmental tracers in subsurface hydrology. Kluwer Academic Publishers. $P$ 31-78.

Hoefs J. 1997. Stable Isotope Geochemistry. $4^{\text {th }}$ ed. Spinger-Verlag. Berlin.

IAH. 2016. About IAH-MAR. http://recharge.iah.org/recharge/default.html. (12.04.2016) Johnson Al and Finlayson DJ. 1988. Artificial recharge of groundwater. Proc. $1^{\text {st }}$ Int. Symp. on Artificial Recharge of Groundwater. ASCE, Reston, VA.

Knorr D and Cliett T. 1985. Proposed groundwater recharge at El Paso, Texas. Artificial recharge of groundwater. Butterworth Publishers, Stoneham, MA, 425-480.

Kosasaeng K and Kayankarnnavy C. 2013. Modeling of Groundwater Flow for Aquifer Atorage Recovery Project in Sukhothai Province. In Proceedings of the $9^{\text {th }}$ National Conference, Kasetsart University, Thailand.

Lertsirivorakul R and Schulmeister M. 2014. An Evalution of Aquifer Heterogeneity at the ASR Site, Sukhothai, Upper Chao Phraya Basin, Thailand. In Proceeding of the NGWA Groundwater Summit. Denver, Colorado.

Kendall C and Caldwell EA. 1998. Fundamentals of Isotope Geochemistry. Kendall C and McDonnell JJ., Editors. Isotope tracers in catchment hydrology. Elsevier: Amsterdam. $839 \mathrm{p}$.

Mook WG. 2001. Environmental Isotopes in the Hydrological Cycle: Principles and Applications. Vol I. IAEA-UNESCO. Vienna. 164 p.

Mungkang P, Lertsirivorakul R, Schulmeister M. 2015. An Evaluation of Dispersivity in Solute Transport Modeling of the Aquifer Storage and Recovery Project in Sukhothai Province. KKU Res J (GS), 15 (3).

Naftz DL, Peterman ZE, Spangler LE. 1997. Using ${ }^{87}$ Sr values to identify sources of salinity to a freshwater aquifer, Greater Aneth Oil Field, Utah, USA. Chemical Geology, 141(34): 195-209. 
Neumann W and Huster $\mathrm{H}$. 1974. The half-life of ${ }^{87} \mathrm{Rb}$ measured as a difference between ${ }^{87} \mathrm{Rb}$ and ${ }^{85} \mathrm{Rb}$. Z. Phy. 270: 121-127.

Nier AO. 1950. A redetermination of the relative abundances of the isotopes of carbon, nitrogen, oxygen, argon, and potassium. Physical Review, 77(6): 789-793.

Peterman ZE, Thamke J, Futa K, Preston T. 2012. Strontium isotope systematics of mixing groundwater and oil-field brine at Goose Lake in northeastern Montana, USA. Applied Geochemistry, 27(12): 2403-2408.

Phien-wej N, Giao PH, Nutalaya P. 1998 Field experiment of artificial recharge through a well with reference to land subsidence control, Engineering Geology 50: 187-201.

Phien-wej N, Giao PH, Nutalaya P. 2006. Land subsidence in Bangkok, Thailand.

Engineering Geology, 82(4): 187-201.

Piper DZ and Bau M. 2013. Normalized Rare Earth Elements in Water , Sediments, and Wine : Identifying Sources and Environmental Redox Conditions. American Journal of Analytical Chemistry 4: 69-83.

Putthividha A and Koonthanakulvong S. 2011. A case study in stable isotope fingerprinting for surface water and groundwater origin and dynamic interactions in Thailand: Proc. 12th international conference on Environmental Science and Technology, Rhodes, Greece. P 1521-1531.

Pyne RDG. 1995. Groundwater recharge through wells: a guide to aquifer storage recovery. Boca Raton, FL, CRC press. 376 p.

Sheng Z and Zhao X. 2014. Special Issue on Managed Aquifer Recharge: Powerful Management Tool for Meeting Water Resources Challenges, Journal of Hydrologic Engineering 20(3).

United States Environmental Protection Agency (EPA). 2016. Aquifer recharge (AR) and aquifer storage \& recovery (ASR). https://www.epa.gov/uic/aquifer-recharge-andaquifer-storage-and-recovery (12.04.2016).

Veizer J. 1989. Strontium Isotopes in Seawater Through Time. Annual Review of Earth and Planetary Sciences 17: 141-167.

Verhagen BT. 2003. Isotope hydrology and its impact in the developing world. Journal of Radioanalytical and Nuclear Chemistry 257(1): 17-26.

Zuurbier K, Kooiman J, Groen M, Maas B and Stuyfzand P. 2014. Enabling Successfull Aquifer Storage and Recovery of Freshwater Using Horizontal Directional Drilled Wells in Coastal Aquifers. Journal of Hydrologic Engineering 20(3). 


\title{
CHAPTER 2
}

\section{Manuscript I: Isotope- and REE-Characterization of Groundwater Aquifers within the Aquifer Storage and Recovery Program in Sukhothai (N.-Thailand)}

\author{
Manussawee Hengsuwan ${ }^{1,2^{*}}$, Monthon Yongprawat ${ }^{2,3}$, Klaus Simon ${ }^{2}$, Bent T. Hansen ${ }^{2}$ \\ ${ }^{1}$ Department of Groundwater Resources, Bangkok, Thailand \\ ${ }^{2}$ Geoscience Center, Georg-August-University of Göttingen, Göttingen, Germany \\ ${ }^{3}$ Thailand Institute of Nuclear Technology, Nakornnayok, Thailand
}

\section{ABSTRACT}

Aquifer Storage and Recovery (ASR) was a pilot project for solving flood and drought problem in the northern part of Chao Phraya River basin, Thailand. This part of Thailand always faces flooding in rainy season and drought during dry season every year. The overexploitation of groundwater during dry season leads to continuously decline of water level in this area. In this project, the excessive surface water during rainy season was stored by injection of this treated surface water through recharge wells into the underground aquifers. This would serve to raise the water level, which can be extracted for use during the dry season. To assess the efficiency of the ASR process some tracers are required. The aim of this study is to prove the suitability of natural tracers to follow up the artificial recharge process; emphasis will be placed on Strontium (Sr) isotopic composition. The results showed that the change in ${ }^{87} \mathrm{Sr} /{ }^{86} \mathrm{Sr}$ ratios could be observed during an artificial recharge due to the different isotopic fingerprint of surface water and groundwater. However, the flow direction of the injected water cannot be clearly interpreted because of the limited number of monitoring wells, small distance between each monitoring well and the short duration of injection.

Keywords: Sr-isotope, rare earth elements (REE), aquifer storage and recovery (asr), Thailand 


\section{INTRODUCTION}

The Upper Chao Phraya River basin is a mountainous area alternately with low land area along the river, which is located in the northern part of Thailand and covers the administrative area of Phichit, Pitsanulok and Sukhothai provinces. The basin is composed of four main subbasins: Ping River, Wang River, Yom River and Nan River, which feed into the Chao Phraya River (Figure 1). The annual rainfall in this area ranges from 1000 to $1500 \mathrm{~mm}$ with $80-90 \%$ occurring between May and October (Department of Groundwater resources 2011). This causes flooding in rainy season and drought during dry season every year, especially in the Yom River sub-basin. The Yom River is the only river in this basin with no storage dam to control the surface water. The construction of a storage dam on Yom River basin was recommended in 1973. However, due to the high costs, long construction period and environmental impacts, the project has not been completed. The groundwater was suggested as an intermediate solution to solve the shortage problem during dry season. But in the fact, it is extensively used for agriculture (Department of Groundwater resources 2015). The Sukhothai Groundwater Project is the first groundwater irrigation project in Thailand and is located on Sukhothai plain on both sides of the Yom River in Sukhothai province. Groundwater was extracted from more than 200 wells for agriculture covering an area of 71000 rais (113 $\mathrm{km}^{2}$ ). In 1989 about 50 million $\mathrm{m}^{3}$ of water were pumped from the aquifer, which is higher than the safe yield value of 40 million $\mathrm{m}^{3} /$ year. The overexploitation of groundwater leads to the continuous decline of the groundwater level in this area.

In 2008, the Department of Groundwater Resources initiated a project to solve the drought problem by the Aquifer Storage and Recovery (ASR) Method, including the design and construction of an ASR station. ASR relies on storing available or excess water in an aquifer as an artificial recharge to be recovered when needed. The artificial recharge test was performed previously in 1973 for mitigation of land subsidence in the Bangkok area. The main 
problems, which occurred during the test were clogging and outbreaks of injected water ca 10 m away from the recharge well (Klaus et al. 2007, Phien-wej et al. 1998).

The aim of this study is to assess the use of strontium isotopes and rare earth elements (REE) to determine the flow paths during the artificial recharge of surface water into the aquifers. Strontium isotopes have been proven as an effective tracer because they occur naturally and are not fractionated by geochemical reactions (e.g. mineral dissolution and precipitation) Klaus et al. 2007, Land et al. 2000, Négrel et al. 2005). The difference in strontium isotope ratios reflects the different sources of strontium, which is usually associated with the weathering source. Therefore, this strontium ratio can be used to identify mixing sources and pathways (Clark 2015).

\section{STUDY SITE}

The ASR site was constructed in Khung Yang village, Pa Kum Ko subdistrict, Sawankalok district, Sukhothai province (Figure 1). The study are consists of solid rocks including sedimentary, metamorphic, and igneous rock of various ages, namely Silurian-Devonian rocks, Carboniferous rocks, Permo-Carboniferous rocks, Permian rocks, Triassic rock, Jurassic rocks, Upper Cretaceous-Tertiary rocks, and Quaternary basalt; covered by Quaternary sediments consisting of

1. Quaternary flood plain deposit (Qfd) consisting of sand and gravel interbedded with clay layers. This deposit was found along the bank of Yom River, flood plains and old waterways.

2. Quaternary young terrace deposits (Qyt) or Quaternary lower terrace deposit (Qlt) consists of sandy clay, silt and various size of gravel. This deposit spreads on ground surface and under flood plain deposit.

3. Quaternary old terrace deposits (Qot) or Quaternary higher terrace deposit (Qht) consists of various sizes of gravel, gravelly and clayey sand layers. This deposit was found along mountain slopes under lower terrace and flood plain deposits (Department of Groundwater Resources 2011). 


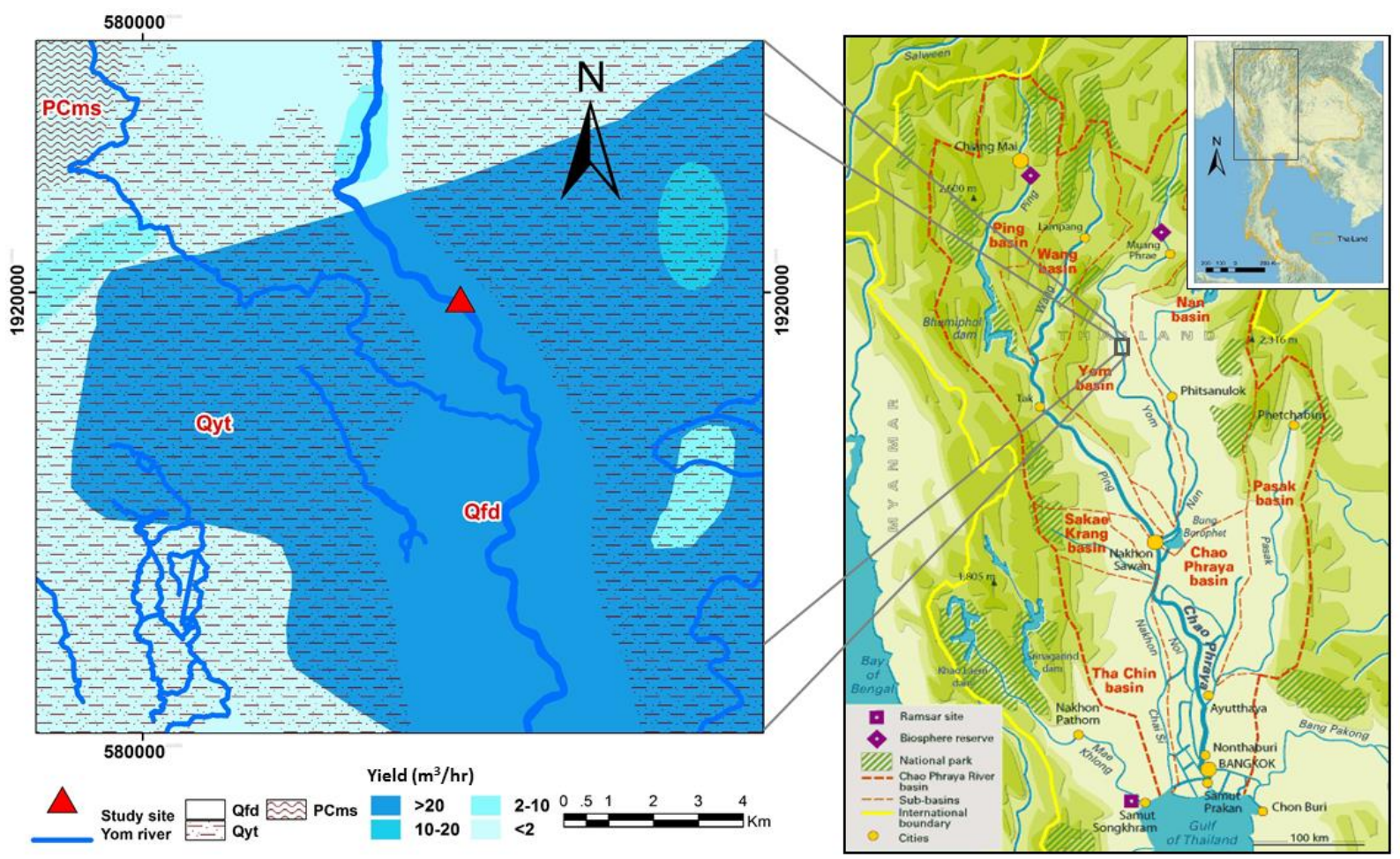

Figure 1. Hydrological map and location map of the study area, which is located in the upper Chao Phraya basin, Thailand (modified after hydrogeological map 1:50,000 of Department of Groundwater Resources and unesco.org).

The aquifers in this area can be classified according to the level of depth into two main aquifers, namely, shallow aquifer with the depth of 35-44 m and deep aquifer with the depth 74-83 m beneath the ground surface.

The ASR site consists of 8 monitoring wells (MWS) and 1 recharge well (RWS2) for the shallow aquifer. As for the deep aquifer there are 8 monitoring wells (MWD), and 1 recharge well (RWD2). Lastly, 1 water treatment plant as shown in Figure 2.

Water from the Yom River was pumped to a settling pond before entering the water treatment system. This system consists of the chemical addition of Aluminium Sulfate for precipitation, clarification through Lamella type clarifier, filtration through a sand filter and disinfection by addition of chlorine liquid compound $(\mathrm{NaOCl})$. The treated water was injected into the recharge wells by pump pressure method. After the injection was completed, the recharged water was stored in the aquifer for a period of ca. 2 weeks as to complete the homogenization between 


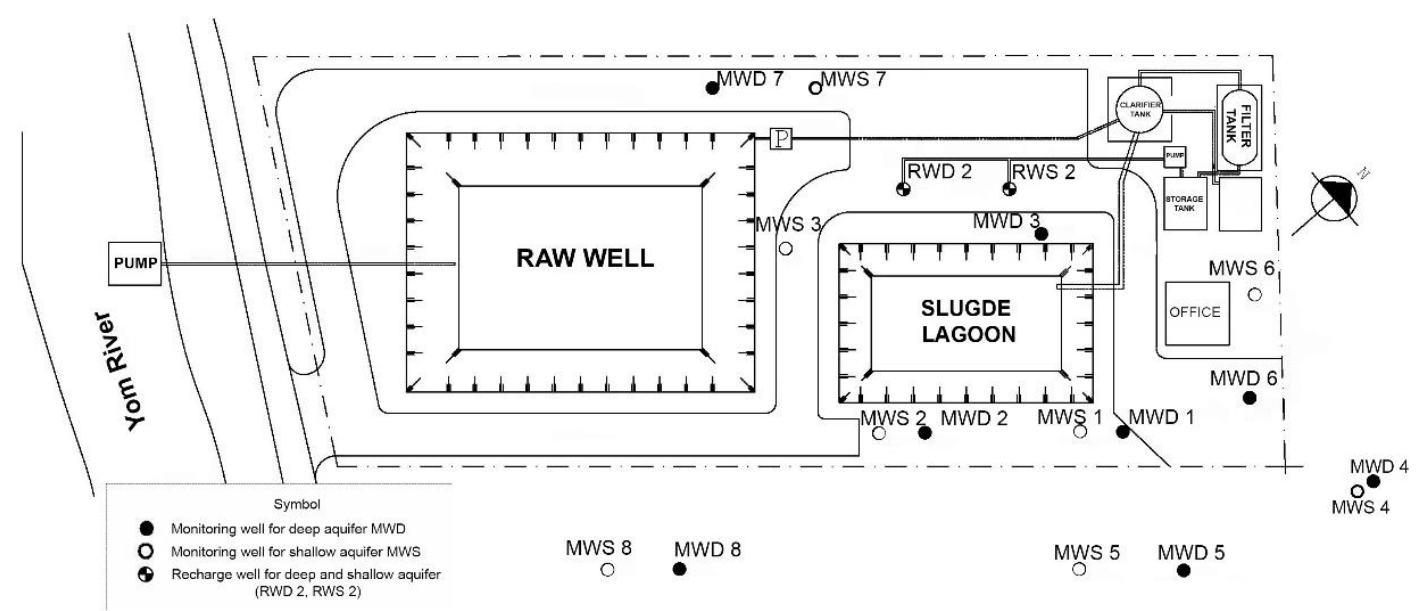

Figure 2. Map of monitoring wells and recharge wells location.

the recharged water and original groundwater in the aquifer. The recovery of the recharged water for use was performed by extraction of 1 to 2 times the net volume of injected water by using a submersible pump, which was installed in the recharge well. In 2012 and 2013 long term ASR testing was performed by the pump pressure method. The details of long term ASR testing are summarized in Table 1.

Table 1. Detail of sampling and recharge/extraction rate.

\begin{tabular}{|c|c|c|c|c|c|c|c|c|c|c|}
\hline \multirow[b]{2}{*}{$\begin{array}{c}\text { ASR } \\
\text { testing } \\
\text { in year }\end{array}$} & \multirow[b]{2}{*}{ event } & \multirow[b]{2}{*}{ remark } & \multicolumn{4}{|c|}{ MWS } & \multicolumn{4}{|c|}{ MWD } \\
\hline & & & $\begin{array}{l}\text { sampling } \\
\text { date }\end{array}$ & duration & $\begin{array}{c}\text { rate of } \\
\text { injection/ } \\
\text { extraction }\end{array}$ & $\begin{array}{l}\text { total volume } \\
\text { of injection/ } \\
\text { extraction }\end{array}$ & $\begin{array}{l}\text { sampling } \\
\text { date }\end{array}$ & duration & $\begin{array}{c}\text { rate of } \\
\text { injection/ } \\
\text { extraction }\end{array}$ & $\begin{array}{c}\text { total } \\
\text { volume of } \\
\text { injection/ } \\
\text { extraction }\end{array}$ \\
\hline \multirow{2}{*}{2012} & - & $\begin{array}{c}\text { before } \\
\text { injection }\end{array}$ & - & \multirow{2}{*}{ - } & - & - & 16.10 .2012 & \multirow{2}{*}{$\begin{array}{c}18.10- \\
17.11 .2012 \\
\text { (30 days) }\end{array}$} & \multirow{2}{*}{$\begin{array}{l}50-55 \\
\mathrm{~m}^{3} / \mathrm{hr}\end{array}$} & \multirow{2}{*}{$18949 \mathrm{~m}^{3}$} \\
\hline & - & $\begin{array}{c}\text { after } \\
\text { injection }\end{array}$ & - & & - & - & 17.11 .2012 & & & \\
\hline \multirow{7}{*}{2013} & 0 & $\begin{array}{c}\text { before } \\
\text { injection }\end{array}$ & 3.08 .2013 & - & - & - & 3.08 .2013 & - & - & - \\
\hline & 1 & \multirow{3}{*}{ injection } & 12.09 .2013 & \multirow{3}{*}{$\begin{array}{c}14.08- \\
9.10 .2013 \\
\text { (57 days) }\end{array}$} & \multirow{3}{*}{$\begin{array}{l}20-23 \\
\mathrm{~m}^{3} / \mathrm{hr}\end{array}$} & \multirow{3}{*}{$26872 \mathrm{~m}^{3}$} & 28.08.2013 & \multirow{3}{*}{$\begin{array}{c}14.08- \\
27.09 .2013 \\
\text { (45 days) }\end{array}$} & \multirow{3}{*}{$\begin{array}{l}16-19 \\
\mathrm{~m}^{3} / \mathrm{hr}\end{array}$} & \multirow{3}{*}{$20802 \mathrm{~m}^{3}$} \\
\hline & 2 & & 27.09 .2013 & & & & 12.09 .2013 & & & \\
\hline & 3 & & 9.10 .2013 & & & & 27.09 .2013 & & & \\
\hline & 4 & storage & 13.10 .2013 & $\begin{array}{c}10.10- \\
28.10 .2013 \\
\text { (17 days) }\end{array}$ & & & 9.10 .2013 & $\begin{array}{c}28.09- \\
10.10 .2013 \\
\text { (13 days) }\end{array}$ & & \\
\hline & 5 & \multirow{2}{*}{$\begin{array}{l}\text { recovery/ } \\
\text { extraction }\end{array}$} & 8.11 .2013 & \multirow{2}{*}{$\begin{array}{c}29.10- \\
20.11 .2013 \\
\text { (23 days) }\end{array}$} & \multirow{2}{*}{$\begin{array}{l}60-62 \\
\mathrm{~m}^{3} / \mathrm{hr}\end{array}$} & \multirow{2}{*}{$35471 \mathrm{~m}^{3}$} & 19.10 .2013 & \multirow{2}{*}{$\begin{array}{c}11.10- \\
27.10 .2013 \\
\text { (17 days) }\end{array}$} & \multirow{2}{*}{$\begin{array}{l}55-56 \\
\mathrm{~m}^{3} / \mathrm{hr}\end{array}$} & \multirow{2}{*}{$23507 \mathrm{~m}^{3}$} \\
\hline & 6 & & 23.11 .2013 & & & & 27.10 .2013 & & & \\
\hline
\end{tabular}

\section{SAMPLING AND ANALYTICAL METHODS}

To obtain hydrochemical and isotopic data, groundwater samples from 8 shallow aquifer monitoring wells (MWS1-MWS8) and groundwater samples from deep aquifer monitoring wells (MWD1-MWD8) were collected. In 2012 before injection started, the groundwater samples from the deep- and the shallow aquifer monitoring wells were collected for rare earth elements and Sr-isotope analyses. After the injection was completed, only groundwater 
samples from the deep aquifer were collected again for Sr-isotope analysis to compare the results with the ones before injection.

In 2013 groundwater samples were collected from both the shallow and the deep aquifer for analyses of Sr-isotope, stable isotopes ( $\delta \mathrm{D}$ and $\left.\delta^{18} \mathrm{O}\right)$, anions and REE. The sampling was separated into four periods, namely: before injection ( 1 time, event 0 ), during injection (3 times, event 1-3), aquifer storage (1 time, event 4) and groundwater extraction (2 times, event 5-6) as shown in table 1. For comparison, samples from rain water, surface water (Yom River) and injected water were also collected. For the third event, the samples MWD4, MWD5, WWD8 were not collected as well as the samples MWS4, MWS5, WWS8 from the second and the fourth event.

All samples due to be analyzed for rare earth elements and Sr-isotope measurements were filtered through a $0.45 \mu \mathrm{m}$ membrane filter and acidified to $\mathrm{pH} 2$ with concentrated doubledistilled $\mathrm{HNO}_{3}$. Water samples collected for rare earth elements were determined by ICP-MS on a PerkinElmer DRC II (Sciex, Canada) at the department of Geochemistry (Geoscience Centre, University of Göttingen, Germany). Non-acidified water samples for stable isotopes $\left(\delta \mathrm{D}\right.$ and $\delta^{18} \mathrm{O}$ ) measurement were analyzed by Liquid Scintillation Counter (Tricarb 3180 $\mathrm{TR} / \mathrm{SL}$ ) after electrolytic enrichment and Major anion were measured by Dionex, ICS-3000 at the Thailand Institute of Nuclear Technology (TINT). Sr concentrations and isotopic

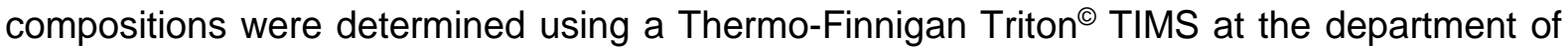
Isotope Geolog (Geoscience Centre, University of Göttingen, Germany). Prior to digestion, samples were mixed with a tracer solution enriched in ${ }^{87} \mathrm{Rb}-{ }^{84} \mathrm{Sr}$. Detailed description of the analytical procedure for water samples are given in Wiegand et al. (2001) and Klaus et al. (2007). Throughout this work a value of $0.710267 \pm 0.000041(2 \sigma)$ for the NBS $987(n=10)$ was observed. Instrumental mass fractionation was corrected with a ${ }^{88} \mathrm{Sr} /{ }^{86} \mathrm{Sr}$ ratio of 0.1194 using exponential law. 


\section{RESULTS}

\subsection{Initial Long Term ASR Testing by Pump Pressure Method in Year 2012}

\subsubsection{Strontium Isotopes}

Sr isotopic data are shown in Figure 3. The ${ }^{87} \mathrm{Sr} /{ }^{86} \mathrm{Sr}$ ratios of surface waters from Yom River has high Sr content compared to the groundwater ranging between 0.203-0.205 $\mu \mathrm{g} / \mathrm{g}$ and ${ }^{87} \mathrm{Sr} /{ }^{86} \mathrm{Sr}$ ratios ranging from 0.70920 to 0.70944 . Sr content and ${ }^{87} \mathrm{Sr} /{ }^{86} \mathrm{Sr}$ ratios of the injected water were $0.201 \mu \mathrm{g} / \mathrm{g}$ and 0.70929 , respectively. The groundwater in the shallow aquifer can be clearly differentiated from the groundwater in the deep aquifer by Sr concentration and ${ }^{87} \mathrm{Sr} /{ }^{86} \mathrm{Sr}$ ratios The Shallow aquifer in this study case can be classified by low Sr content and high ${ }^{87} \mathrm{Sr} /{ }^{86} \mathrm{Sr}$ ratios, whereas the deep aquifer exhibited a high $\mathrm{Sr}$ content and lower ${ }^{87} \mathrm{Sr} /{ }^{86} \mathrm{Sr}$ ratios

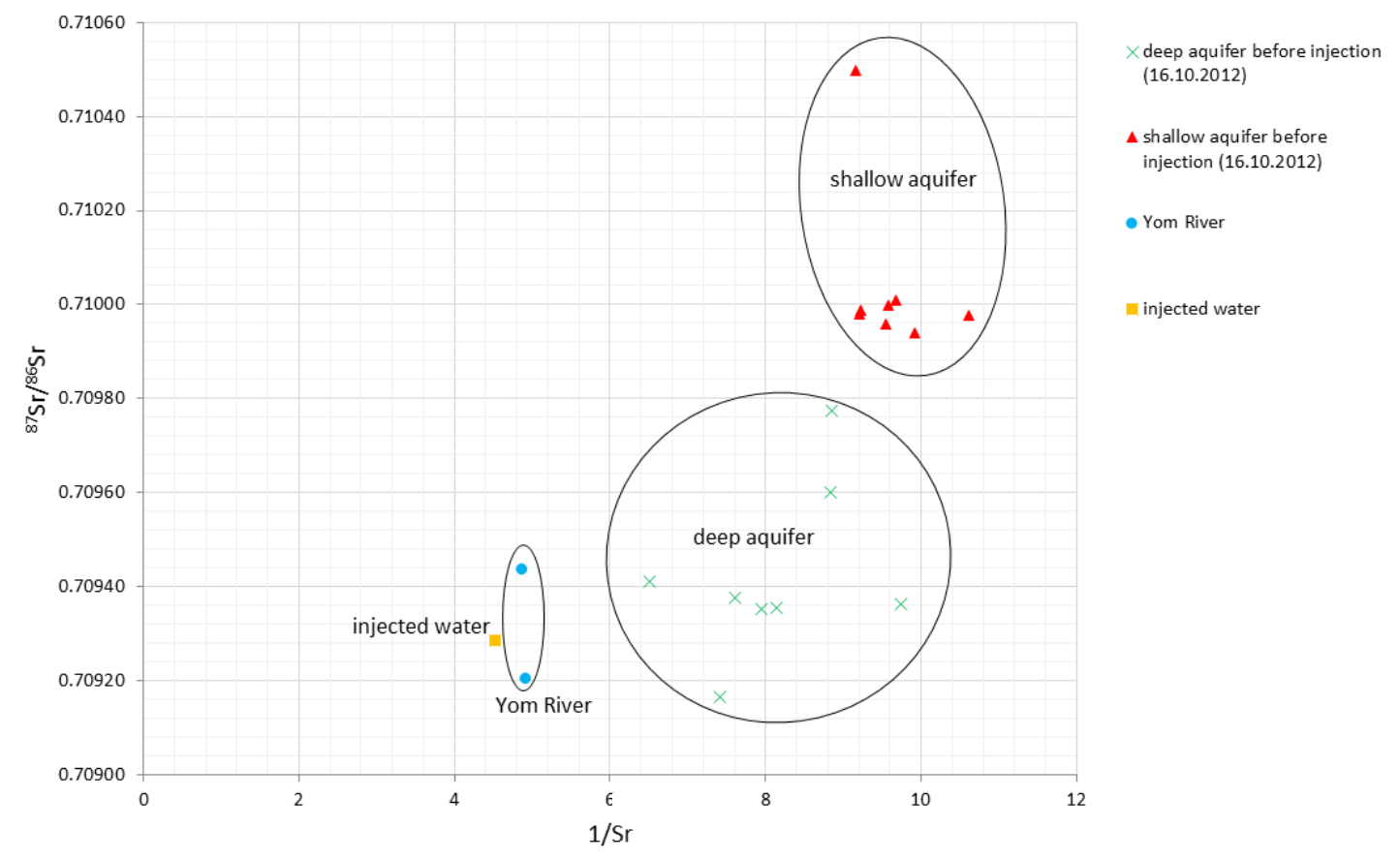

Figure 3. Correlation between ${ }^{87} \mathrm{Sr} /{ }^{86} \mathrm{Sr}$ and $1 / \mathrm{Sr}$ of shallow aquifer, deep aquifer injected water and surface water (Yom River) samples. 


\subsubsection{Strontium Isotopes and REE in the deep aquifer after initial long term ASR}

\section{testing}

In Figure $4,{ }^{87} \mathrm{Sr} /{ }^{86} \mathrm{Sr}$ ratios are plotted against the reciprocal $\mathrm{Sr}$ concentration of deep aquifer groundwaters before and after injection. The hypothetical mixing line for binary mixing would have a linear trend connecting the end members. Some of the data (i.e., MWD1, MWD2 and MWD6) follow a linear trend between the injected water and the groundwater samples before injection, representing the points after injection in-between, more or less close to the mixing line. The abundance of the injected water component in each groundwater sample can be calculated by equation

$$
\mathrm{f}_{\mathrm{A}}=\frac{\left({ }^{87} \mathrm{Sr} /{ }^{86} \mathrm{Sr}\right)_{\mathrm{C}}-\left({ }^{87} \mathrm{Sr}^{86} \mathrm{Sr}_{\mathrm{B}}\right) \times \frac{\mathrm{Sr}_{\mathrm{B}}}{\mathrm{Sr}_{\mathrm{C}}}}{\left({ }^{87} \mathrm{Sr} r^{86} \mathrm{Sr}\right)_{\mathrm{A}} \times \frac{\mathrm{Sr}_{\mathrm{A}}}{\mathrm{Sr}_{\mathrm{C}}}-\left({ }^{87} \mathrm{Sr} r^{86} \mathrm{Sr}_{\mathrm{B}} \times \frac{\mathrm{Sr}_{\mathrm{B}}}{\mathrm{Sr}_{\mathrm{C}}}\right.}
$$

Subscripts A, B and C refer to injected water, groundwater sample before injection and groundwater sample after injection respectively (Faure and Mensing 2005)

The groundwater samples after injection in MWD1, MWD2 and MWD6 may contain about $12 \%, 9 \%$ and $21 \%$ injected water component, respectively.

In addition to the above discussed analyses, all samples were investigated for their rare earth element concentrations (Appendix I). The REE concentrations show the characteristic zigzag pattern according to the Oddo-Harkins Rule (Mason 1966, Schmidt et al. 1963, Wildman and Haskin 1965) The heavy REE concentrations (Eu-Lu) in most samples are below detection limit. The REE concentrations in surface water samples are relative high compared to those in groundwater samples. The REE concentration pattern can be smoothed out by normalizing the REE on an element by element to some standard. In this study, REE abundances are normalized to the upper continental crust (UCC) (Piper and Bau 2013) and plotted on logarithmic scale as shown in Figure 5. Deep aquifer groundwaters and Yom River sample show a relatively flat to slightly enriched pattern in medium REE (MREE) relative to the light REE (LREE). 


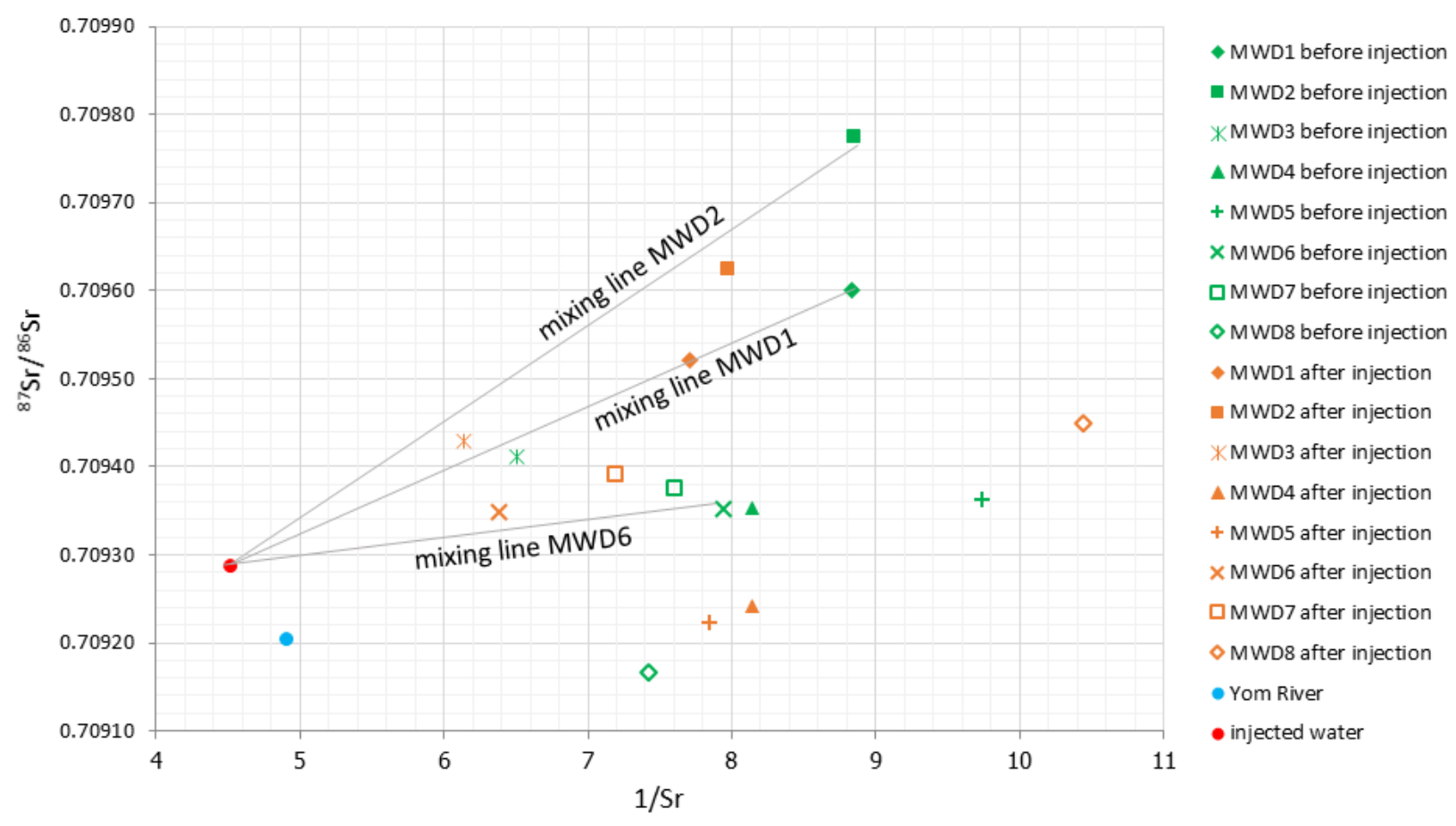

Figure 4. Correlation between ${ }^{87} \mathrm{Sr} /{ }^{86} \mathrm{Sr}$ and $1 / \mathrm{Sr}$ of deep aquifer injected water sample. The hypothetical mixing line for binary mixing would have a linear trend connecting the end members.

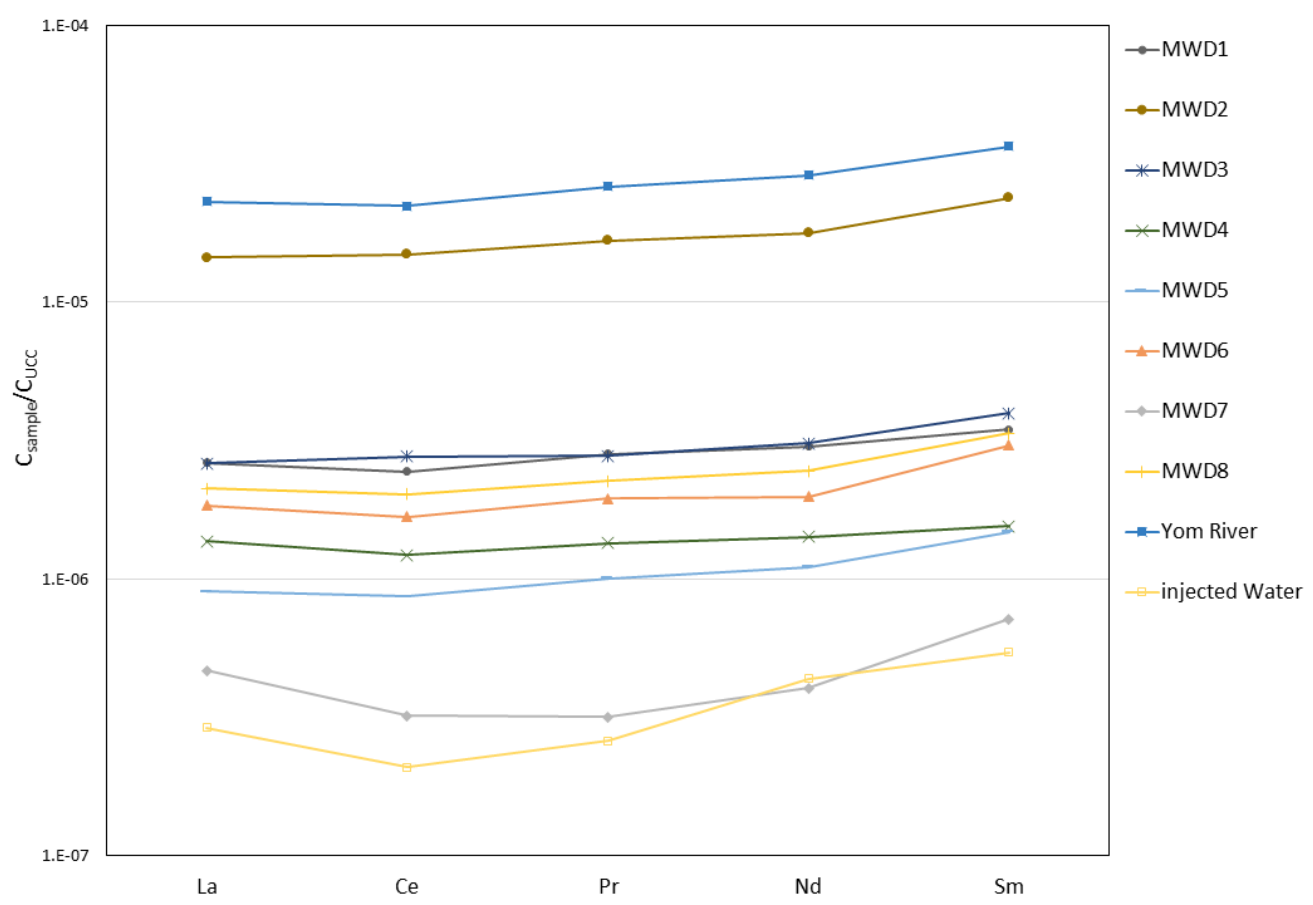

Figure 5. The UCC-normalized REE curve of deep aquifer groundwaters before injection, Yom River and injected water. 
Furthermore, a systematic variation of the rare earth elements concentrations before and after injection has been observed. After injection, the REE concentrations of all deep aquifer groundwater samples have been increased. The rise of REE concentrations can be also used to estimate the amount of injected water in each monitoring wells. In this study, the concentrations of La were chosen as a tracer. Binary mixing is supposed between injected water and groundwater before injection as representing the end members. The results of the calculated mixtures are shown in Figure 6 and indicate the flow direction of injected water to be in southeastern.

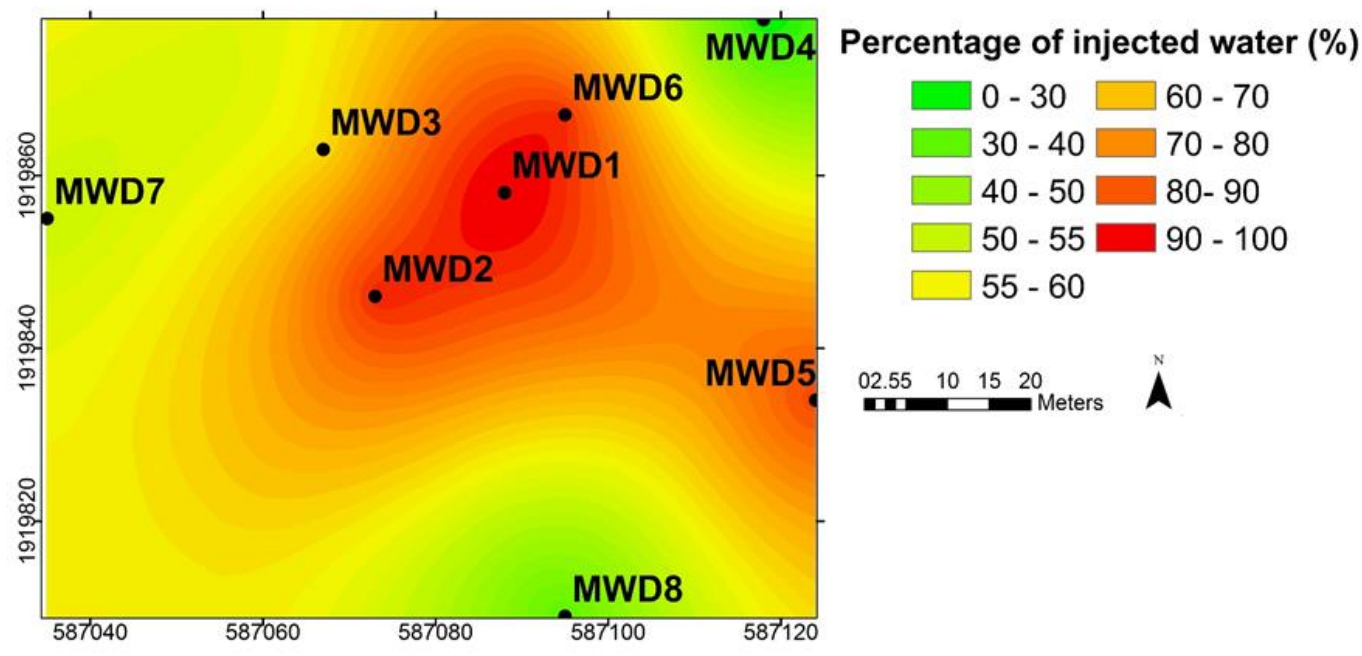

Figure 6. The flow direction of deep aquifer was constructed from the concentration of La.

\subsection{Long Term ASR Testing by Pump Pressure Method in Year 2013}

\subsubsection{Water Level}

\subsubsection{Shallow Aquifer}

The relationship between the water level of the recharge wells and the water level of the monitoring wells before injection, during injection and during extraction for shallow aquifer is shown in Figure 7. Before injection the water level of all wells are very close to each other. The statistic water level of the monitoring wells ranges from $47.03-47.12 \mathrm{~m}$ above Mean Sea Level (MSL). Treated water was injected into recharge well RWS2 with a recharge rate of 20$23 \mathrm{~m}^{3} / \mathrm{hr}$. 
During injection water began to flow in every direction and headed in southwest-west and southeast-east direction. The water level of recharge well RWS2 was elevated from 47.73 to $52.44 \mathrm{~m}$ (MSL) and the water levels of the monitoring wells (MWS1-MWS8) were drawn up 1.8 - $2.0 \mathrm{~m}$. After the injection was completed the injected water was stored in the aquifer for 17 days. After that water was extracted from the aquifer at the rate of $60-62 \mathrm{~m}^{3} / \mathrm{hr}$. The water levels in the monitoring wells during extraction are lower than the statistic water levels before injection by about $3 \mathrm{~m}$ and the water level of recharge well RWS2 is lower than that before injection by about $12 \mathrm{~m}$.

\subsubsection{Deep Aquifer}

The statistic water level of the monitoring wells (MWD1-MWSD) ranges from $45.77-45.85 \mathrm{~m}$ (MSL). By injection at the recharge rate of $16-19 \mathrm{~m}^{3} / \mathrm{hr}$ the water level of recharge well RWD2 was drawn up from 47.93 to $59.48 \mathrm{~m}$ (MSL) and the water levels of the monitoring wells (MWD1-MWD8) were drawn up 1.0 - $1.4 \mathrm{~m}$.

During injection water began to flow in every direction and headed in southeast direction. After injection the water was stored in the aquifer for 13 days to complete the homogenization between the injected water and the original groundwater in the aquifer. The groundwater was extracted from recharge well RWD2 at a rate of 55-56 $\mathrm{m}^{3} / \mathrm{hr}$. Water levels in the monitoring wells are lower than the statistic water levels before injection by about $3 \mathrm{~m}$ and water level of RWD2 recharge well is lower than that before injection by about $8 \mathrm{~m}$. 
a) Shallow Aquifer
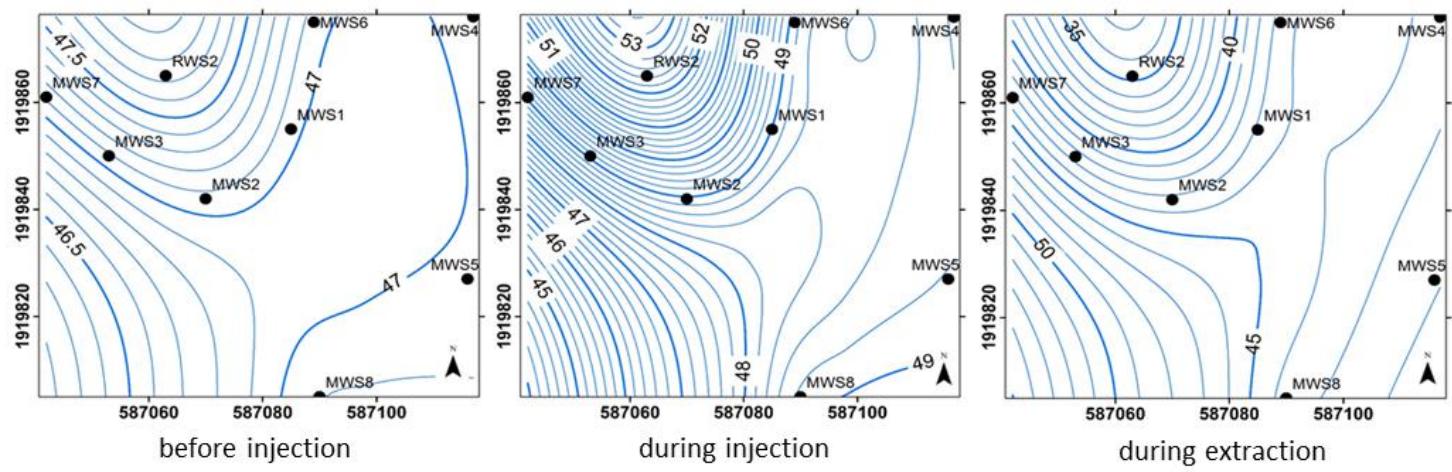

b) Deep Aquifer
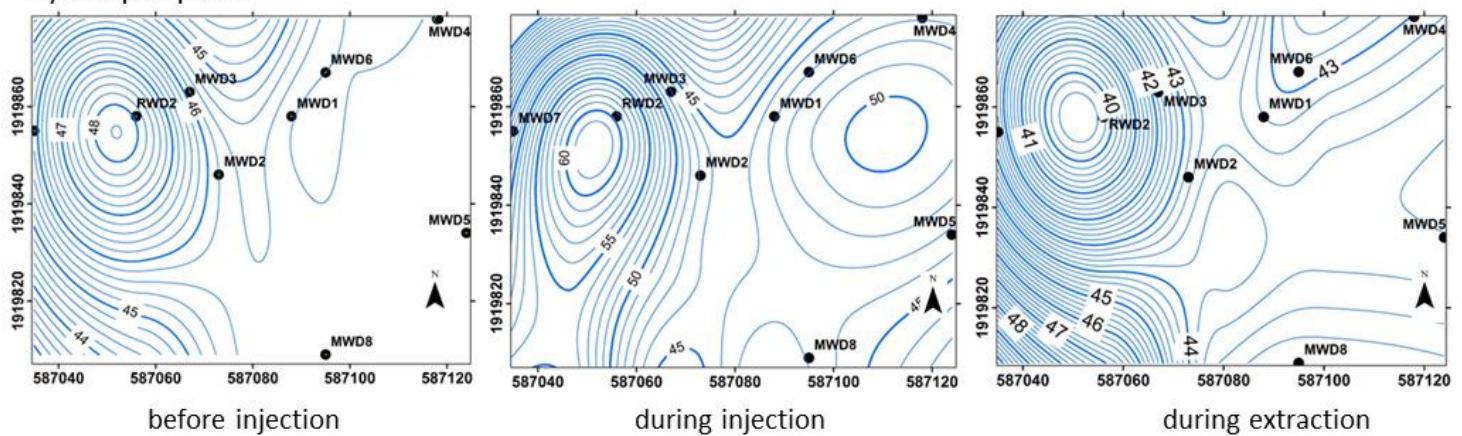

Figure 7. Water level in [m] above Mean Sea Level (MSL) before injection, during injection and during extraction of the shallow (a) and the deep aquifer (b).

\subsubsection{Strontium Isotopes}

$\mathrm{Sr}$ isotopic data are given in Appendix II. The ${ }^{87} \mathrm{Sr} /{ }^{86} \mathrm{Sr}$ ratios of all sampled water can be classified in four groups namely, monitoring wells of shallow aquifer (MWS1-MWS8), monitoring wells of deep aquifer (MWD1-MWD8), injected water and surface water. Surface waters from Yom River have high Sr content compared to the groundwater ranging between $0.176-0.202 \mu \mathrm{g} / \mathrm{g}$ and ${ }^{87} \mathrm{Sr} /{ }^{86} \mathrm{Sr}$ ratios ranging from 0.70934 to 0.70978 . Sr content of injected water ranges from 0.126 to $0.173 \mu \mathrm{g} / \mathrm{g}$, whereas ${ }^{87} \mathrm{Sr} /{ }^{86} \mathrm{Sr}$ ratios varied little and ranges from 0.70951 to 0.70960 .

\subsubsection{Shallow Aquifer}

Before injection, the groundwater in the shallow aquifer can be clearly differentiated from the groundwater in the deep aquifer by distinct $\mathrm{Sr}$ isotopic compositions. The Shallow aquifer in this study case can be classified by low $\mathrm{Sr}$ content and high ${ }^{87} \mathrm{Sr} /{ }^{86} \mathrm{Sr}$ ratios. The $\mathrm{Sr}$ content and ${ }^{87} \mathrm{Sr} /{ }^{86} \mathrm{Sr}$ ratios before the injection ranged from 0.099 to $0.117 \mu \mathrm{g} / \mathrm{g}$ and 0.70967 to 0.71050 respectively. The variation in ${ }^{87} \mathrm{Sr} /{ }^{86} \mathrm{Sr}$ ratios of the shallow aquifer before injection, 
during injection, storage and during extraction were interpolated by ArcGIS program as shown in Figure 8 and Figure 9. Before injection, the groundwater in this aquifer had relatively high ${ }^{87} \mathrm{Sr} /{ }^{86} \mathrm{Sr}$ ratios compared to the injected water, which had mean the ${ }^{87} \mathrm{Sr} /{ }^{86} \mathrm{Sr}$ ratio of 0.70956 . Figure 8 shows the dispersion of injected water during injection and storage period. The result shows that the downgradient monitoring well MWS3 is the most affected by the injected water that flowed outward in the southwestern direction. The ${ }^{87} \mathrm{Sr} /{ }^{86} \mathrm{Sr}$ ratios were close to that of the injected water. Whereas the ${ }^{87} \mathrm{Sr} /{ }^{86} \mathrm{Sr}$ ratios in the monitoring wells farther away from the recharge well were relatively constant with standard deviation of $\pm 7^{*} 10^{-5}, \pm 9^{*} 10^{-6}$ and $\pm 2^{\star} 10^{-5}$ for the monitoring wells MWS4, MWS5and MWS8, respectively.
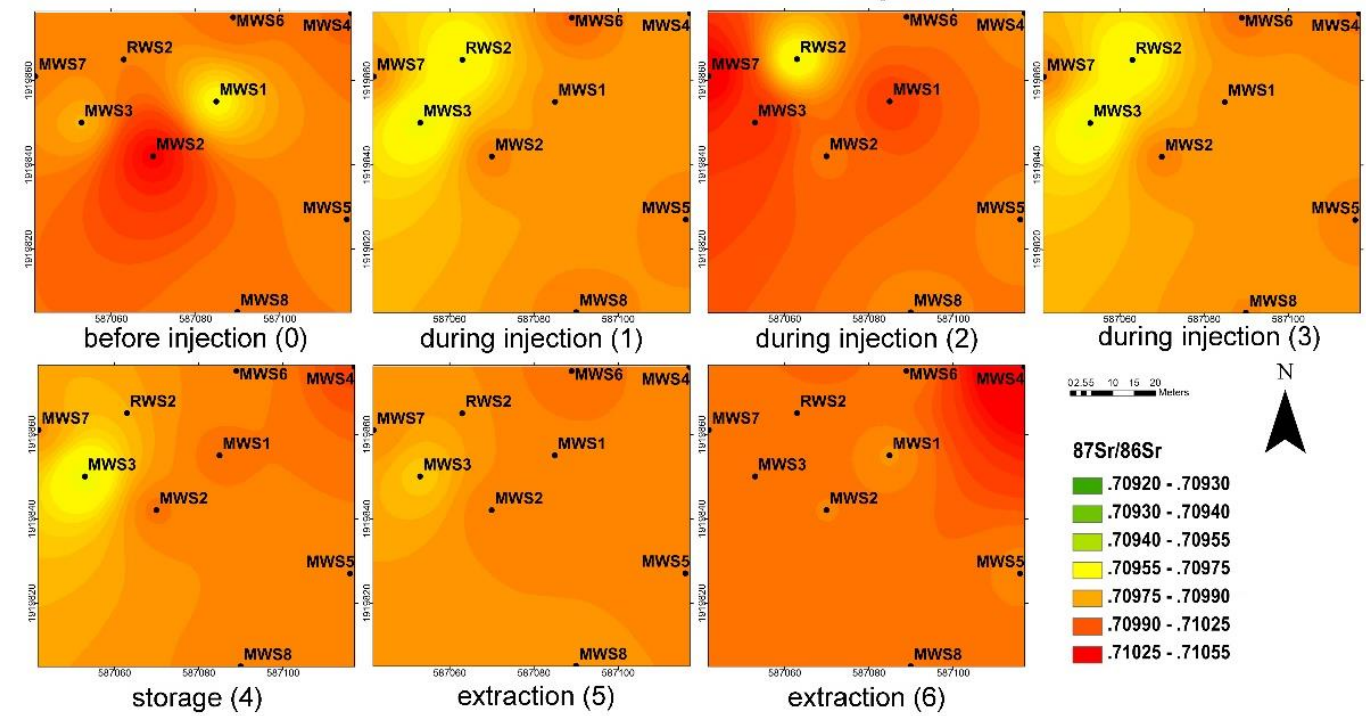

Figure 8. The variation in ${ }^{87} \mathrm{Sr} / 86 \mathrm{Sr}$ ratios of the shallow aquifer before injection, during injection, storage and during extraction.

\subsubsection{Deep Aquifer}

The deep aquifer can be classified by high $\mathrm{Sr}$ content and low ${ }^{87} \mathrm{Sr} /{ }^{86} \mathrm{Sr}$ ratios, which ranged from 0.107 to $0.134 \mu \mathrm{g} / \mathrm{g}$ and 0.70923 to 0.70965 respectively. The variation in ${ }^{87} \mathrm{Sr} /{ }^{86} \mathrm{Sr}$ ratios for the deep aquifer before injection, during injection, storage and during extraction are shown in Figure 9. Before injection, groundwater in this aquifer had relative low ${ }^{87} \mathrm{Sr} /{ }^{86} \mathrm{Sr}$ ratios compared to the injected water, which had the mean ${ }^{87} \mathrm{Sr} /{ }^{86} \mathrm{Sr}$ ratio of 0.70956 . Figure 9 shows the dispersion of the injected water during injection and storage period. The result shows that the injected water started with omnidirectional flow, reached MWD3 before entering MWD6 and headed in the southern and southwestern directions. The change of ${ }^{87} \mathrm{Sr} /{ }^{86} \mathrm{Sr}$ ratios in 
MWD4, MWD5 and MWD8 is insignificant and can be considered as constant values. This means that the injected groundwater did not reach the outside wells. After extraction, the ${ }^{87} \mathrm{Sr} /{ }^{86} \mathrm{Sr}$ ratios seemed to return to the original values before injection.

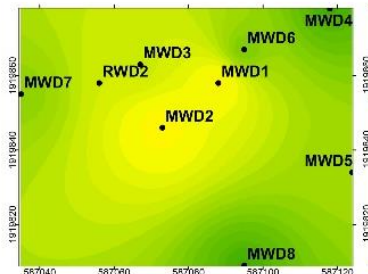

before injection $(0)$

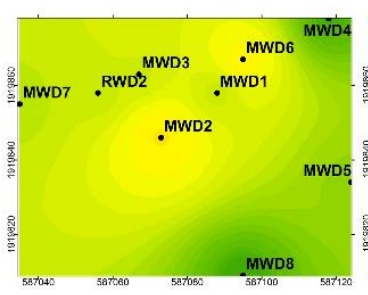

storage (4)

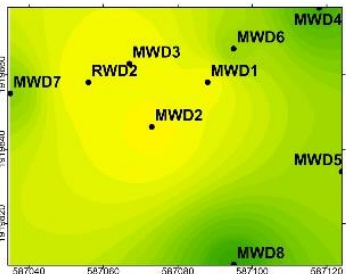

during injection (1)

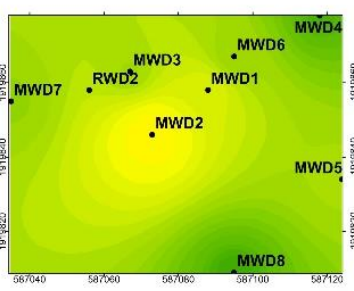

extraction (5)

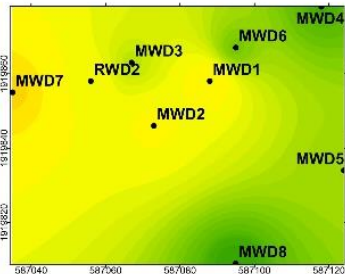

during injection (2)

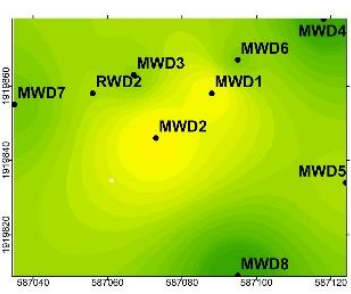

extraction (6)

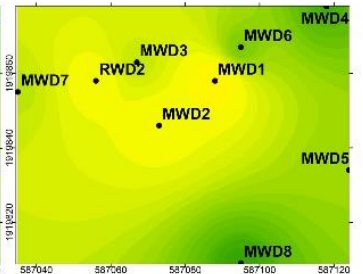

during injection (3)
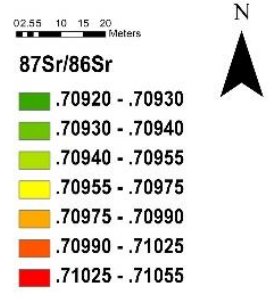

Figure 9. The variation in ${ }^{87} \mathrm{Sr} /{ }^{86} \mathrm{Sr}$ ratios of the shallow aquifer before injection, during injection, storage and during extraction.

\subsubsection{Anions}

Concentrations of Anions $\left(\mathrm{Br}, \mathrm{Cl}, \mathrm{F}, \mathrm{NO}_{3}, \mathrm{PO}_{4}\right.$ and $\left.\mathrm{SO}_{4}\right)$ of the groundwater from the shallow and deep aquifer monitoring wells, injected water and surface water (Yom River) are summarized in Appendix II. $\mathrm{Br}$ and $\mathrm{PO}_{4}$ concentrations in most water samples are below detection limit. $\mathrm{F}$ and $\mathrm{NO}_{3}$ concentrations in the shallow and in the deep aquifer are lower than 0.7 and $3.3 \mathrm{ppm}$, respectively. $\mathrm{SO}_{4}$ concentration ranges from 3.3 to $27.9 \mathrm{ppm}$. Cl concentrations in injected water (18 - 23 ppm) were significantly higher than those in the deep and shallow aquifers (4 - $13 \mathrm{ppm})$. The high difference in $\mathrm{Cl}$ concentration between the injected water and the groundwater in the aquifer can be used to trace the flow of injected water as shown in Figure 10 and Figure 11. 


\subsubsection{Shallow Aquifer}

In the shallow aquifer the injected water started moving with omnidirectional flow, it reached the closest downgradient monitoring wells MWD3 and MWD1 before entering MWD7, MWD6 and MWD2 as shown in Figure 10. Only a small amount of $\mathrm{Cl}$ could be detected in MWD4, MWD5 and MWD8. Thereafter the groundwater flowed in a south-southwestern direction in accordance with the regional flow direction. During extraction the $\mathrm{Cl}$ concentrations have gradually decreased. The extraction was preferentially performed from the downgradient wells and the injected water could be completely extracted from the shallow aquifer. After extraction, the $\mathrm{Cl}$ concentration seemed to return to the original values before injection.
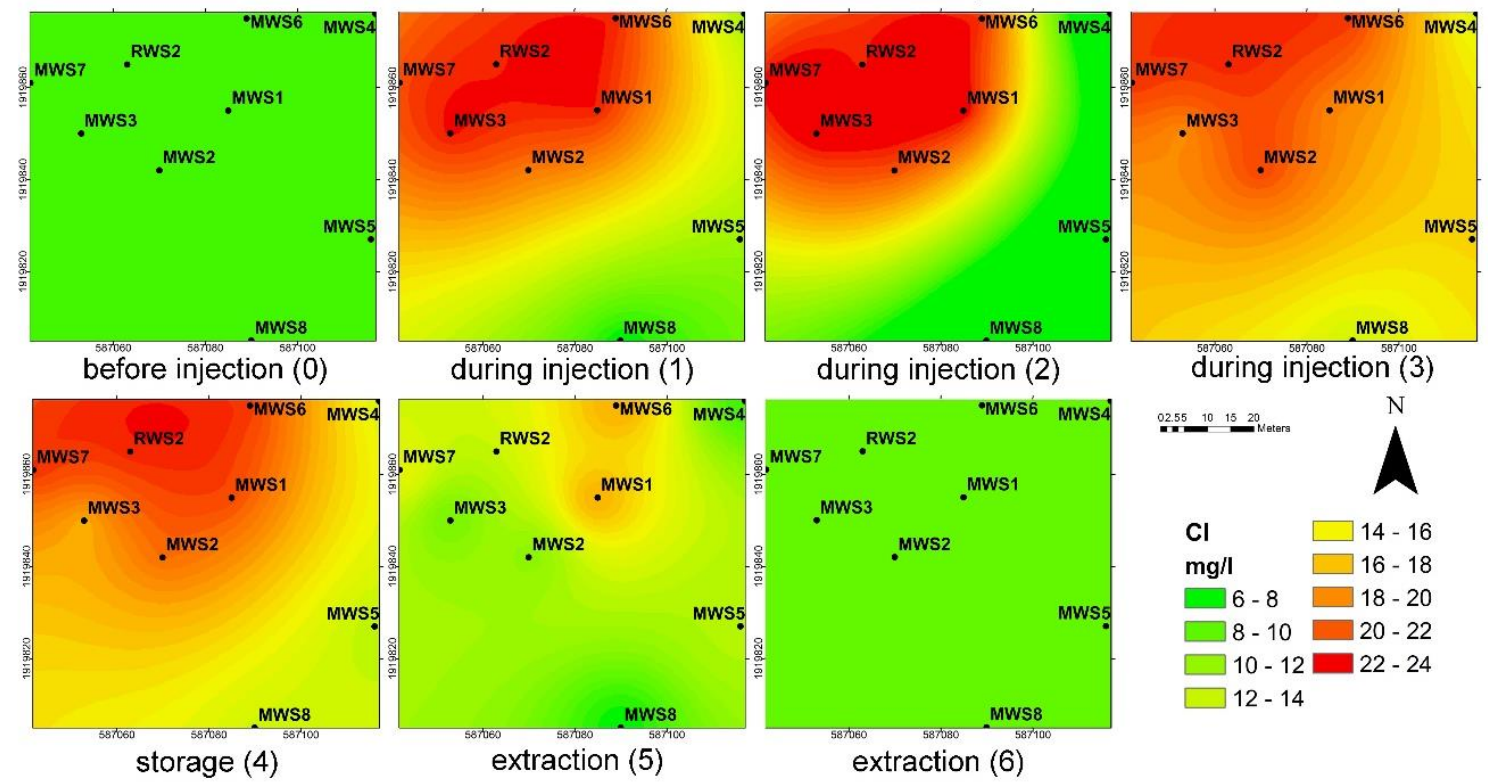

$\mathrm{mg} / \mathrm{l} \quad \square 16-18$

$6-8 \square 18-20$

$\square$ - $-10 \square 20-22$

$\square 10-12 \square 22-24$

$\square 12-14$

Figure 10. The change in $\mathrm{Cl}$ concentration of shallow aquifer before injection, during injection, storage and extraction.

\subsubsection{Deep Aquifer}

Figure 11 shows that the injected water started with omnidirectional flow, reached the closest monitoring wells MWD3 and MWD7 before entering MWD2 and MWD6. The injected water flowed in east- later in southwestern direction. Only a small amount of $\mathrm{Cl}$ could be detected in MWD4 and MWD8. Whereas the change in the Cl concentration in the distant downgradient wells MWD5 was insignificant. This means that the injected water reached the downgradient monitoring wells MWD5 and MWD8 only in small amounts. During extraction the $\mathrm{Cl}$ 
concentrations have gradually decreased. Nevertheless, the extraction was not completed as planned because $\mathrm{Cl}$ could still be found in some wells.

\subsubsection{Stable Isotopes ( $\delta D$ and $\left.\delta^{18} O\right)$}

The variation of stable isotopes $\left(\delta \mathrm{D}\right.$ and $\left.\delta^{18} \mathrm{O}\right)$ are summarized in Appendix II. The $\delta \mathrm{D}$ and $\delta^{18} \mathrm{O}$ values in the injected water ranges between $-48 \%$ to $-38 \%$ and -6.5 to -4.5 , respectively. The $\delta D$ and $\delta^{18} \mathrm{O}$ in injected water during the beginning of injection was more enriched than that by the later injection. This could be the result of evaporation effect, which could have happened during the long storage period in the storage tank before injection.

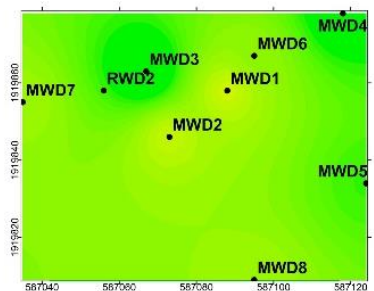

before injection (0)

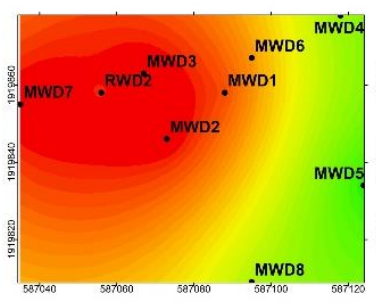

storage (4)

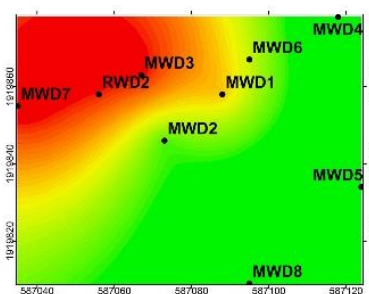

during injection (1)

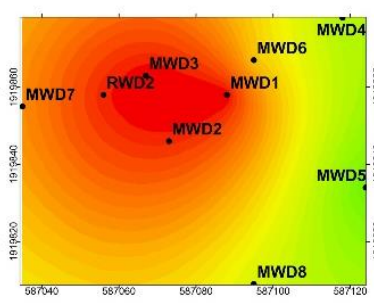

extraction (5)

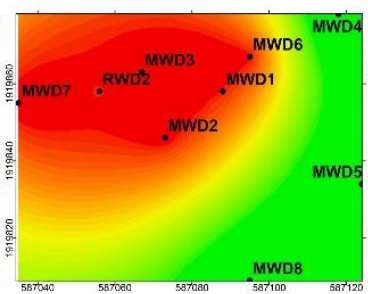

during injection (2)

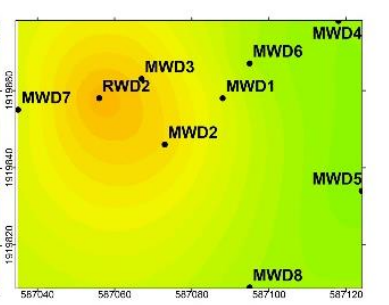

extraction (6)

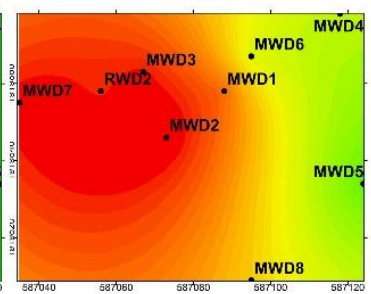

during injection (3)

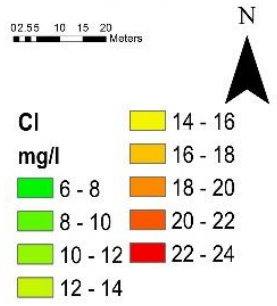

$\square 12-14$

Figure 11. The change in $\mathrm{Cl}$ concentration of deep aquifer before injection, during injection, storage and extraction.

\subsubsection{Shallow Aquifer}

Figure 12 shows that the $\delta \mathrm{D}$ and $\delta^{18} \mathrm{O}$ are enriched in the first event and gradually become depleted from event 2 to event 6 . The succession of $\delta D$ and $\delta^{18} \mathrm{O}$ for the first event during injection is MWS6 > MWS1, MWS7 >MWS3, MWS5, MWS2, MWS8 > MWS4. In event 3 the succession of $\delta D$ and $\delta^{18} \mathrm{O}$ has changed as follow MWS1 > MWS3, MWS2 > MWS6, MWS7, MWS8 > MWS4, MWS5. This means that during injection groundwater in the shallow aquifer started to flow in every direction because the close monitoring wells are more affected and 
then the water heads to the southewest direction. After extraction, the $\delta \mathrm{D}$ and $\delta^{18} \mathrm{O}$ changed values close to those of the native groundwater before injection.
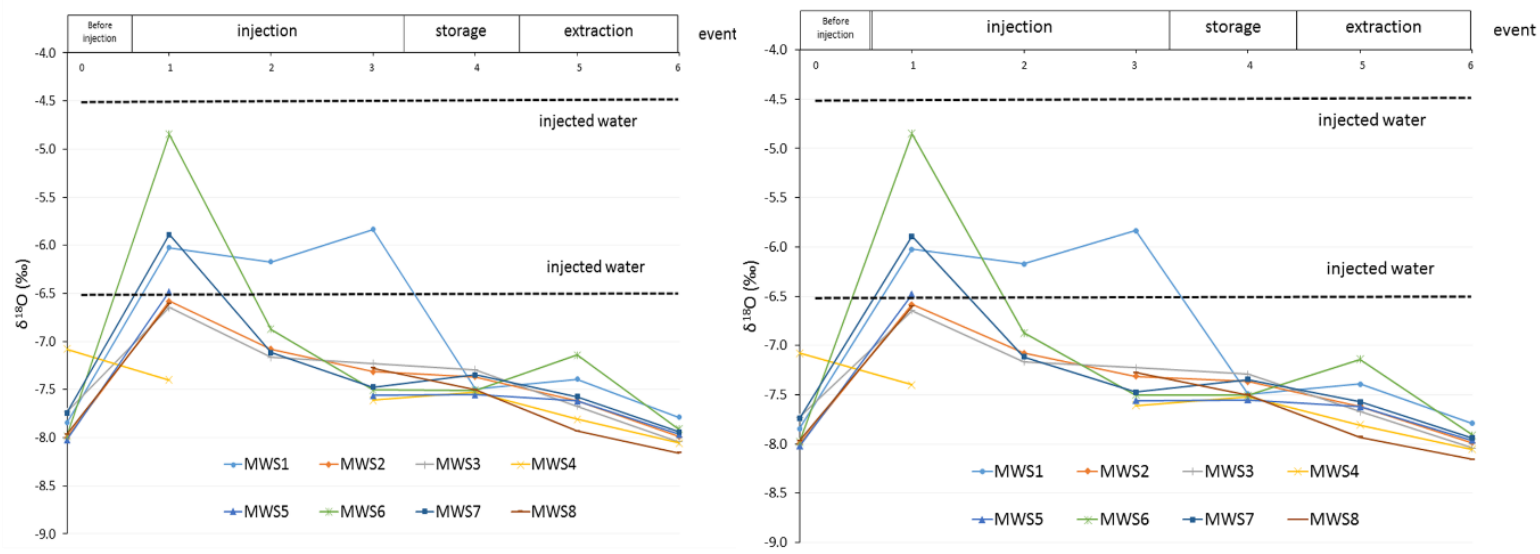

Figure 12. The variation of stable isotopes $\left(\delta \mathrm{D}\right.$ and $\left.\delta^{18} \mathrm{O}\right)$ in shallow aquifer before injection, during injection, storage and extraction.

\subsubsection{Deep Aquifer}

Figure 13 shows that the $\delta D$ and $\delta^{18} \mathrm{O}$ are gradually enriched in the first event and reach the most enriched value in the second event. Then the value becomes more depleted from event 3 to event 6 . The succession of $\delta \mathrm{D}$ and $\delta^{18} \mathrm{O}$ for the second event during injection is MWD7 > MWD3 > MWD2 >MWD4, MWD6, MWD8 > MWD5. The monitoring wells, which are close to the RWD2 recharge well (MWD7, MWD3, MWD2), are most affected. Whereas the change of $\delta \mathrm{D}$ and $\delta^{18} \mathrm{O}$ in other wells is insignificant.
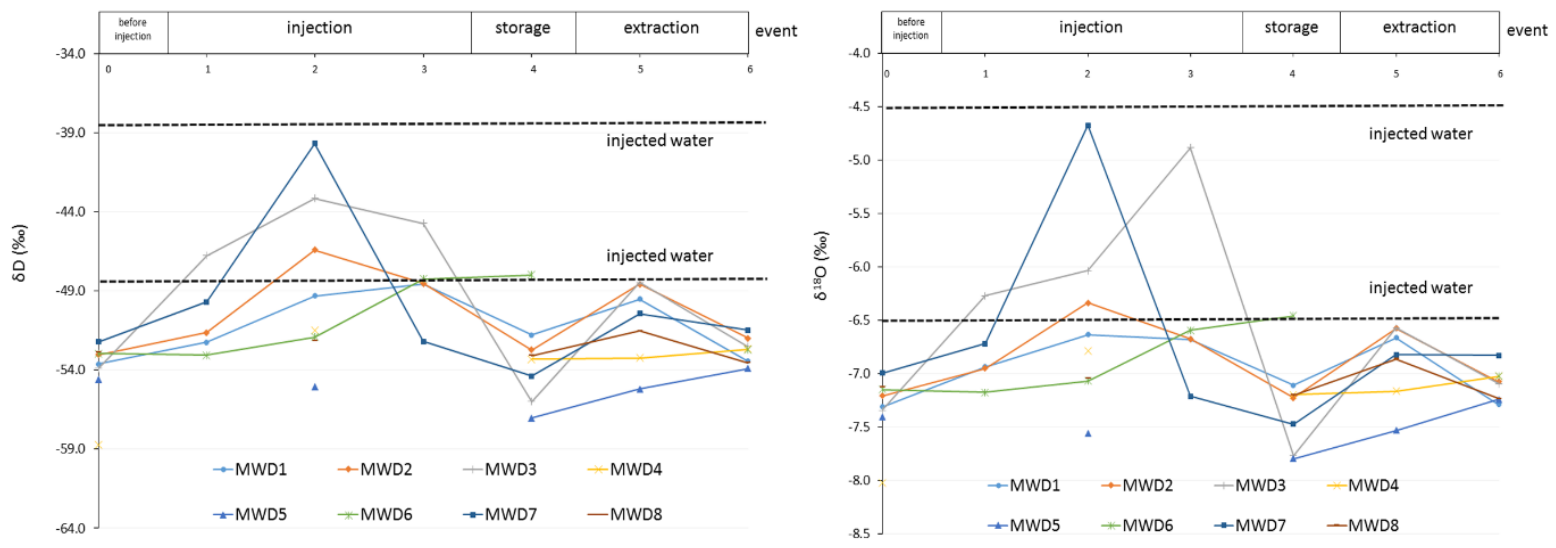

Figure 13. The variation of stable isotopes $\left(\delta \mathrm{D}\right.$ and $\left.\delta^{18} \mathrm{O}\right)$ in deep aquifer before injection, during injection, storage and extraction. 


\subsubsection{Rare Earth Elements (REE)}

REE concentrations of shallow and deep aquifer monitoring wells are summarized in Appendix III. REE concentrations of injected water varied strongly within the time of investigation. The change in the concentrations of the Yom River seems to vary strongly as an effect of meteoric waters draining into the river. This is shown in Figure 14 for the Ce-concentration representing the most abundant element. The Ce concentration increased after heavy rainfall. Therefore, it is not possible to model the movement of water based on REE concentrations as it was for Sr-isotopes.

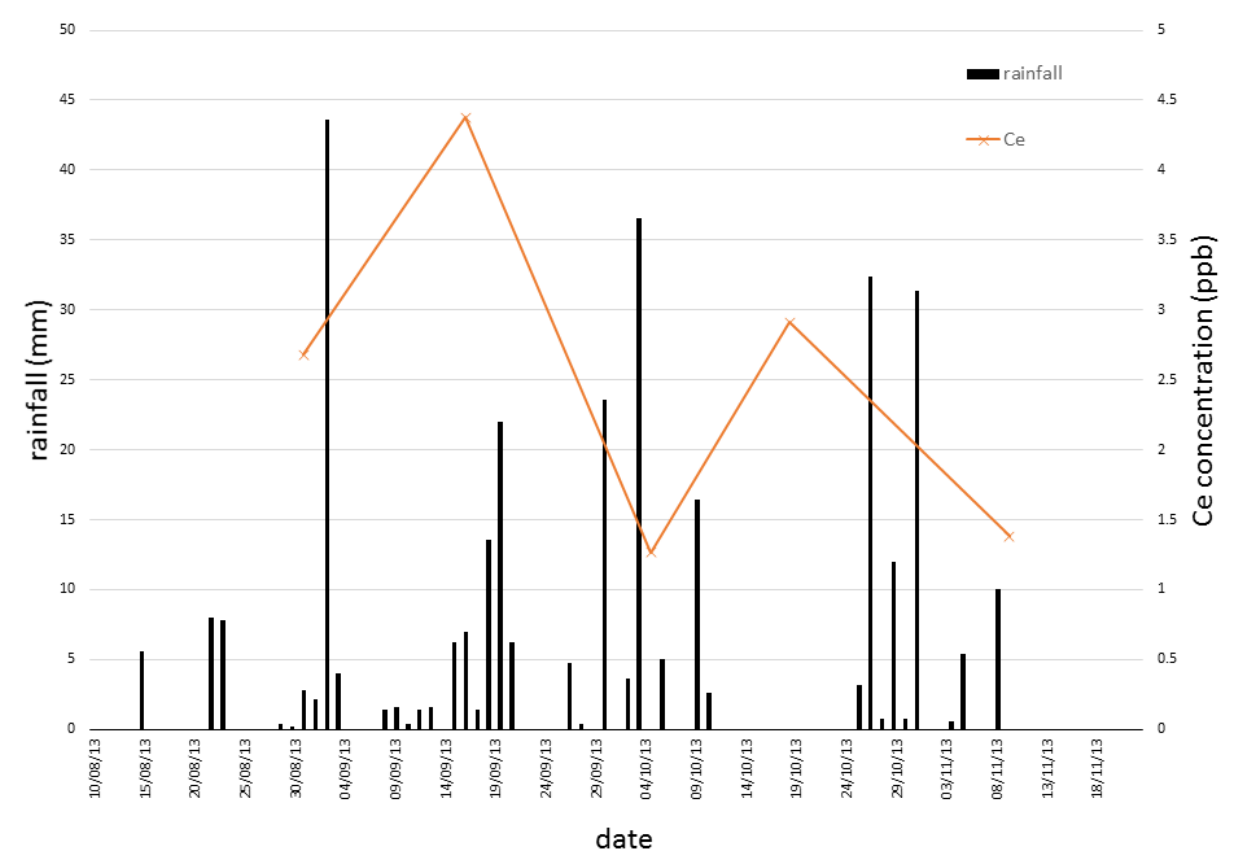

Figure 14. Influence of rainfall on the concentration of $\mathrm{Ce}$ in the Yom River.

\section{DISCUSSION}

In this study Strontium isotopic ratio $\left({ }^{87} \mathrm{Sr} /{ }^{86} \mathrm{Sr}\right.$ ), stable isotopes ( $\delta \mathrm{D}$ and $\delta^{18} \mathrm{O}$ ), chloride concentration and REE concentration were used to trace the flow path during injection and extraction within ASR project to prove the suitability of natural tracers and to evaluate the achievement of this project. Results from all tracers show a similar trend of the flow path with omnidirectional flow at the beginning of injection and then headed to the southwestern direction. Only the result of La concentration by initial long term ASR testing in year 2012 show the flow in southeastern direction. Obvious variations can be found in the monitoring wells 
close to the recharge wells (MWS1, MWS2, MWS3, MWS6, MWS7, MWD1, MWD2, MWD3, MWD6, MWD7). Only small variations can be found in the monitoring well farther away from the recharge wells (MWS4, MWS5, MWS8, MWD4, MWD5, MWD8). The results from the tracers also show that the efficiency for recharge and extraction of the shallow aquifer is better than the deep aquifers.

Strontium is an appropriate tracer because it occurs naturally and is neither affected by geological processes nor fractionation (Klaus et al. 2007). For this study, the shallow aquifer can be distinguished from the deep aquifer due to the difference of concentrations of $\mathrm{Sr}$ and ${ }^{87} \mathrm{Sr} /{ }^{86} \mathrm{Sr}$ ratios. The ${ }^{87} \mathrm{Sr} /{ }^{86} \mathrm{Sr}$ ratio variations within a hydrogeological system can provide information about the source of Sr and the mixing processes (Négrel et al. 1997, Négrel et al. 2001). The variations of ${ }^{87} \mathrm{Sr} /{ }^{86} \mathrm{Sr}$ ratios can be observed, especially for the monitoring wells, which are close to the recharge well either in the shallow or in the deep aquifer. An important thing that must be taken into account is the difference in values of ${ }^{87} \mathrm{Sr} /{ }^{86} \mathrm{Sr}$ ratios between the injected water and the native groundwater in the aquifer. Some results of the groundwater samples are different from the injected water by the fifth decimal place only. Therefore, it is not easy to distinguish, if those values are the result of mixing or not. Stable isotopes ( $\delta \mathrm{D}$ and $\left.\delta^{18} \mathrm{O}\right)$ can be usually used to characterize groundwater from different sources. The problem for this study is the inconsistence of the $\delta \mathrm{D}$ and $\delta^{18} \mathrm{O}$ composition in the injected water due to fractionation that occurs during evaporation and it is not easy to control the constant values of $\delta D$ and $\delta^{18} \mathrm{O}$ in injected water. Consequently, $\delta D$ and $\delta^{18} \mathrm{O}$ are not the suitable tracers for this study case. $\mathrm{Cl}$ concentration was also used as a tracer in this project because of the concentration difference in injected water and native groundwater. $\mathrm{Cl}$ concentration in treated water are 2-5 times higher than that in the groundwater and can be considered as a suitable tracer for this project. Moreover, it is obvious that opposite to the behavior of REE in brines where the concentrations stayed nearly constant over years (Möller et al. 2005), the present groundwater samples varied strongly within the time of investigation. The change in the concentrations of the Yom River seems to vary strongly as an effect of meteoric waters draining into the river. Nevertheless, there is a big difference in the REE concentrations 
between the Yom River water and the injected water. This is related to the fact that the river water before injection is treated with polyaluminum chloride to avoid the formation of colloids, which might clock the injection. These colloids are precipitated in the clarifier tank before injection.

The injected water changes in concentration with respect to the REE during injection and storage as further complex fractions due to reaction with organic matter is produced in the aquifer, therefore it is not possible to model the movement of water as it was for Sr-isotopes. Nevertheless, the flow path of groundwater in this project cannot be clearly interpreted because of the limited number of monitoring wells, small distance between each monitoring well and short duration of injection.

\section{CONCLUSION}

ASR is one of the alternative technologies that could be applied for solving the drought problem in dry seasons for certain application such as agriculture, consumption and industrial uses. To assess the efficiency of the ASR process some tracers are required. In this case, the concentration of $\mathrm{Cl}$ in injected water is higher than the native groundwater in the aquifer, due to the addition of $\mathrm{NaOCl}$ for disinfection purposes during the treatment of surface water before injection. Therefore, $\mathrm{Cl}$ concentration can be used as an appropriate tracer to track the process during the artificial recharge. However, for a long-term study the ${ }^{87} \mathrm{Sr} /{ }^{86} \mathrm{Sr}$ ratios should be a more suitable tracer, because of their precision. Strontium isotopes are sensitive indicators. Although the changes of ${ }^{87} \mathrm{Sr} /{ }^{86} \mathrm{Sr}$ ratios in some water samples are small, but they are significant. Small amount of contaminants can be already detected by changing the ${ }^{87} \mathrm{Sr} /{ }^{86} \mathrm{Sr}$ ratios. They are not affected by fractionation or mineral precipitation. The isotopic fingerprints of groundwater and surface water can be easily used to track the artificial recharge process, especially when the difference in ${ }^{87} \mathrm{Sr} /{ }^{86} \mathrm{Sr}$ ratios of the injected water and native groundwater are significant. The isotopic changes of groundwater in the aquifer resulting from injected water can be traced. 
The tracer characteristic of $\mathrm{Sr}$ isotopes should be useful for the government to manage groundwater exploitation and groundwater conservation for sustainable use, such as to track the sea water intrusion into the aquifers or to track the illegal groundwater abstraction, which are serious problems now a days.

\section{ACKNOWLEDGEMENTS}

The Authors thank the staffs of SNT consultants and staffs of the Department of Groundwater Resources for fieldwork support during sampling and academic discussion as well as the staffs of Thailand institute of Nuclear Technology for technical support by sample analyses. We thank financial support from the Open Access Publication Fund of Göttingen University. M.H. appreciates the advice and help in the laboratory by Klaus Wemmer, Nicole Nolte, Franziska Wilski and Brigitte Dietrich (all GZG, Göttingen).

\section{REFERENCES}

Clark ID. 2015. Groundwater geochemistry and isotope. CRC Press. 438 p.

Department of Groundwater Resources. 2011. Pilot study and experiment on managed aquifer recharge using ponding system in the lower north region river basin, Pitsanulok, Sukhothai and Pichit provinces. Final report (in Thai), Bangkok, Thailand. 420 p.

Department of Groundwater Resources. 2015. Exploring corrective means for solving Flood and drought problem by ASR method in the northern part of Chao Phraya river basin. Final report (in Thai), Bangkok, Thailand.

Faure G, Mensing TM. 2005. Isotope Principle and Applications $3^{\text {rd }}$ Ed. Hoboken, New Jersey: John Wiley \& Sons, Inc.

Klaus JS, Hansen BT, Buapeng S. 2007. ${ }^{87} \mathrm{Sr} /{ }^{86} \mathrm{Sr}-$ Ratios: A Natural Tracer to characterize the Groundwater of Bangkok Area, Thailand, with respect to Public Water Supply and Freshwater Reinjection, Hydrogeology Journal 15: 745-758.

Land M, Ingri J, Andersson PS and Öhlander B. 2000. Ba/Sr, Ca/Sr and ${ }^{87} \mathrm{Sr} /{ }^{86} \mathrm{Sr}$ ratios in soil water and groundwater: implication for relative contributions to stream water discharge, Applied Geochemistry 15: 311-325.

Mason B. 1966. Principals of Geochemistry, John WileySons, New York.

Möller P, Woith $H$, Dulski $P$, Lüders V, Erzinger J, Kämpf $H$, Pekdeger A, Hansen BT, Lodemann M, Banks D. 2005. Main and trace elements in the KTB-VB fluid: composition and hints to its origin. Geofluids 5: 28-41. 
Négrel P, Fouillac C and Brach M. 1997. A Strontium isotopic study of mineral and surface waters from the Cézallier (Massif Central, France): implications for mixing processes in areas of disseminated emergences of mineral water, Chemical Geology 135: 89101.

Négrel P, Cassanova J and Aranyossy JF. 2001. Strontium isotope systematics use to decipher the origin of groundwaters sampled from granitoids: the Vienne Case (France). Chemical Geology 177: 287-308.

Négrel P, Petelet-Giruad E. 2005. Strontium isotopes as tracers of groundwater induced floods: the Sommer case study (France), Journal of Hydrology 305: 99-119.

Phien-wej N, Giao PH, Nutalaya P. 1998 Field experiment of artificial recharge through a well with reference to land subsidence control, Engineering Geology 50: 187-201.

Piper D and Bau M. 2013. Normalized Rare Earth Elements in Water, Sediments, and Wine: Identifying Sources and Environmental Redox Conditions, American Journal of Analytical Chemistry 4 (10A): 69-83.

Schmidt RA, Smith, RH, Lasch JA, Olehy AWA and Vasilevshis J. 1963. Abundances of Fourteen Rare-Earth Elements, Scandium, and Yttrium in Meteoritic and Terrigenous Matter, Geochimica et Cosmochi- mica Acta 27(6): 577-622.

Wiegand B, Dietzel M, Bielert U, Groth P, Hansen BT. 2001. ${ }^{87} \mathrm{Sr} /{ }^{86} \mathrm{Sr}-$ Verhältnisse als Tracer für hydrochemische Prozesse in einem Lockergesteinsaquifer (Libenau, NWDeutschland), Acta. Hydrochem. Hydrobiol. 29(2-3): 139-152.

Wildman TR and Haskin L. 1965. Rare-Earth Elements in Ocean Sediments. Journal of Geophysical Research 70(12): 2905-2911. 


\section{CHAPTER 3}

\section{Manuscript II: Long-Term Investigation of Sr-Isotope and Rare Earth Element Fractionation Processes within Three Major Aquifers in the Äspö Hard Rock Laboratory (Sweden)}

Manussawee Hengsuwan*, Christine Heim, Klaus Simon, Bent T. Hansen

Geoscience Center, Georg-August-University of Göttingen, Göttingen, Germany

Published in Geomicrobiology Journal, 32:3-4, 243-254

DOI: $10.1080 / 01490451.2014 .962121$

\section{ABSTRACT}

The 450 m deep Äspö Hard Rock Laboratory (Äspö HRL) provides a unique opportunity to access different aquifer systems within the Precambrian granodioritic basement of the Baltic Shield. In this study, emphasis will be placed on systematic variations of the isotopic and chemical composition including fractionation patterns of rare earth elements (REE) of three different aquifers. The aim is to identify end-member groundwater compositions and increase the knowledge and understanding of the groundwater evolution, water rock interaction, parameters which are important for the subsurface microbial activity in the Äspö HRL. Groundwaters at the shallow and intermediate aquifers were influenced most from Baltic Sea water and meteoric water. The analyses of Sr-data and REE show especially long-term groundwater-rock interaction and $\delta^{18} \mathrm{O}$ values indicate the presence of glacial meltwater in the deep aquifer. During the 5 years of investigation, significant chemical changes caused by internal mixing processes or present microbial activity were not observed. 


\section{INTRODUCTION}

Within igneous rocks, the chemical composition of groundwater in fractures can be influenced by different processes like mixing with different water types, interaction with the surrounding minerals and also microbial activity of a deep biosphere. Fluids, minerals, $\mathrm{H}_{2}$ and $\mathrm{CH}_{4}$ from degassing volcanic or plutonic rocks are considered as widespread nutrient and energy sources fuelling microbial metabolism at depth (Amend and Teske 2005; Dobretsov et al. 2006; Pedersen 2000). These chemical modifications may be relevant for long-term processes in the aquifers and may also effect the whole fracture system and the surrounding rock. Therefore, biogeochemical long-term studies of subsurface aquifer systems may enhance the knowledge and understanding of groundwater systems, which may be modified by mixing processes, water rock interactions and microbial activity. The 450 m deep Äspö Hard Rock Laboratory (Äspö HRL) located on the Baltic coast of Sweden is operated since 1995 as a testing site for handling and long-term storage of nuclear waste in Sweden. The Äspö HRL provides a unique opportunity to access different aquifer systems within the Precambrian granodioritic basement of the Baltic Shield. In this study, water sources and geochemical mixing processes of three major aquifers were monitored over several years in order to investigate long-term variations of their major chemical composition. Special focus was on distribution processes of Strontium $\left(\delta^{87} \mathrm{Sr}\right)$, Oxygen $\left(\delta^{18} \mathrm{O}\right)$, Carbon $\left(\delta^{13} \mathrm{C}\right)$ and Sulfur $\left(\delta^{34} \mathrm{~S}\right)$ isotopes as well as main and rare earth elements (REE).

Carbon, Oxygen, Sulfur isotopes have been used for several decades as natural tracers of groundwater for groundwater provenance and recharge processes investigation (e.g., Clark and Fritz 1954; Mc Crea 1950). $\delta^{13} \mathrm{C}$ can be used as a tracer for carbonate evolution in groundwater because of the large variations in different carbon reservoirs (e.g., biogenic $\delta^{13} \mathrm{C}$ fractionation of methane) and $\delta^{18} \mathrm{O}$ is often used for palaeotemperature reconstructions due to fractionation differences of the oxygen isotopes between different phases (e.g., water, air, solids; Mc Crea 1950). $\delta^{34} S$ is especially useful for studying biogeochemical processes in groundwater (e.g., Kaplan and Rittberg 1964; Sim et al. 2011). $\delta^{87} \mathrm{Sr}$ can be used due to the 
geochemical properties for hydrogeological investigation such as groundwater-rock interaction process and groundwater flow path system, in which water may retain the rock signature in its dissolved Sr (Peterman and Wallin 1999; Wiegand et al. 2001; Gosselin et al. 2004). In case of low temperature $\left(12-14^{\circ} \mathrm{C}\right)$ fluids like in Äspö, this process is strongly dependent on the mineralogical composition of the investigated host rock, the salinity and the residence time of the fluid (Fritz et al. 1991; Möller et al. 1997; Glodny and Grauert 2009). However, in our case major changes in the strontium isotope signatures most properly can be related to infiltration and percolation along fracture zones rather than to water-rock interaction.

\section{GEOLOGICAL SETTING AND HYDROGEOLOGY AT THE ÄSPÖ SITE}

The Äspö HRL is a drilled tunnel below the Äspö Island located north of Oskarshamn, SESweden. The island has a slightly undulating topography and is about $10 \mathrm{~m}$ above sea level (Banwart et al. 1996). The Precambrian granodioritic basement of the Baltic Shield in this area belongs to the Transscandinavian Igneous Belt (TIB) and consists of $1.8 \mathrm{Ga}$ old fine grained granite and Äspö diorite, a medium-grained, porphyritic, granitic to quartz-monozodioritic rock (Mansfeld 1996; Mansfeld et al. 2005). The Äspö diorite contains large K-feldspar phenocrysts $(1-2 \mathrm{~cm})$ and the fine-grained granite is an even-grained alkali-granite (Johansson et al. 1998). The last glacial event had the largest impact on the Äspö groundwater system. During melting of the continental ice shield around 12000 a BP, the glacial meltwater penetrated the bedrock (Laaksoharju et al. 1999). Although other stages like the Yoldia Sea and the Ancylus Lake developed in this area after the deglaciation, during the Littorina Sea Stage (7500 a BP), water with a salinity of (15\%) initially penetrated the bedrock (Wallin and Peterman 1999; Wallin et al. 2007). In areas not covered by the Littorina Sea, infiltration of meteoric water began directly after the deglaciation and was even enhanced by the land uplift through the glacial rebound (Wallin et al. 2007; Laaksoharju et al. 2009). However, the Äspö aquifers were not only affected by water intrusions of post glacial times. The groundwater has experienced influence, 
mixing and also water-rock reactions over longer geological timescales. The paleohydrological situation in this area was described in detail by Laaksoharju et al. (2009).

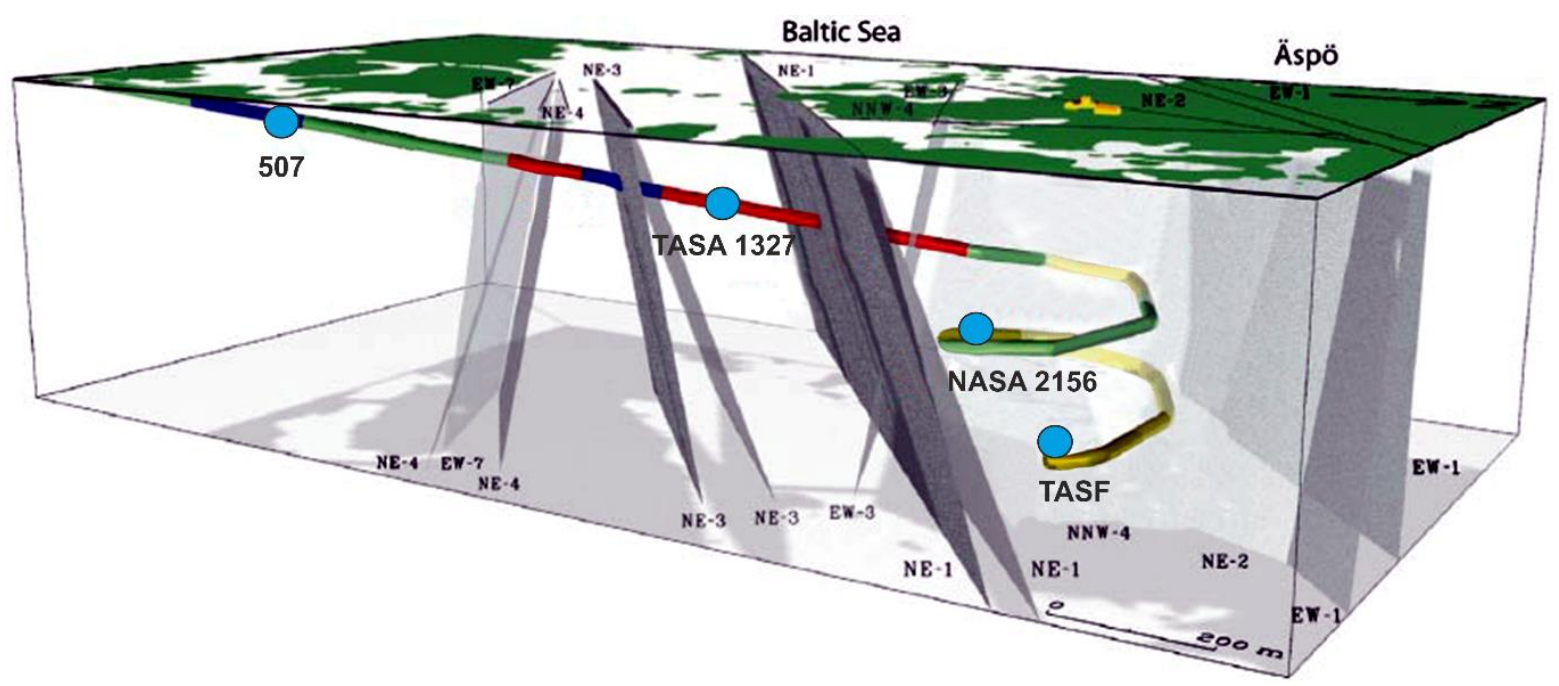

Figure 1. Three sampling sites in Äspö tunnel: TASA 1327, NASA 2156, and TASF. The names with capitals refer to the section of tunnel and the number to the distance from the entrance in meters.

\section{SAMPLING LOCATIONS AND ANALYTICAL METHODS}

Groundwater samples from three major aquifers were investigated at the following tunnel sites: a shallow at TASA 1327 (-183 m, borehole HA1327B), an intermediate at NASA 2156, (-290 m, borehole NASA 2162B:1) and a deep aquifer at TASF (-455 m depth, borehole KF0069A01, Figure 1). The water samples were collected from 2006-2010 in $50 \mathrm{~mL}$ falcon tubes. For comparison, meteoric water (rain and snow), Baltic Sea water and adjacent rock samples were collected. All water samples were filtered through a 0.45 micron membrane filter and acidified to $2 \%$ with concentrated double-distilled $\mathrm{HNO}_{3} . \mathrm{Rb}-\mathrm{Sr}$ analyses were performed on a Thermo-Finnigan Triton TIMS at the department of Geochemistry (Geoscience Centre, University of Göttingen, Germany). Prior to digestion samples were mixed with a tracer solution enriched in ${ }^{87} \mathrm{Rb}-{ }^{84} \mathrm{Sr}$. Rock pieces were sampled close to the aquifer outlets and also investigated. Detailed descriptions for the analytical procedure for water- and whole-rock samples are given in Wiegand et al. (2001), Tütken et al. (2002), and Klaus et al. (2007). During the period of this work a value of $0.710272 \pm 0.000039(2 \mathrm{~s})$ for the NBS $987(n=8)$ 
was observed. Instrumental mass fractionation was corrected with ${ }^{88} \mathrm{Sr} /{ }^{86} \mathrm{Sr}$ of 0.1194 using exponential law, mass fractionation correction for $\mathrm{Rb}$ measurements was achieved via repeated analyses of SRM 984 yielding an ${ }^{85} \mathrm{Rb} /{ }^{87} \mathrm{Rb}$ of $2.6014 \pm 42(\mathrm{n}=12)$. Rubidium measurements were performed under the same conditions and corrected with the factor derived from the standard measurements. ${ }^{87} \mathrm{Sr} /{ }^{86} \mathrm{Sr}$ ratios can be conveniently expressed as per mil (\%) deviation from a modern seawater standard (0.709175, McArthur et al. (2012)); as proposed by Faure and Mensing (2005).

$$
\delta^{87} \mathrm{Sr}=\left(\left(\left({ }^{87} \mathrm{Sr} /{ }^{86} \mathrm{Sr}\right)_{\text {sample }} /\left({ }^{87} \mathrm{Sr} /{ }^{86} \mathrm{Sr}\right)_{\text {standard }}-1\right){ }^{*} 1000 .\right.
$$

Trace and rare earth elements were analysed by ICPMS on a VG Plasma Quad II at the GZG. Major anions $\left(\mathrm{Cl}^{-}, \mathrm{SO}_{4}{ }^{2-}, \mathrm{F}^{-}, \mathrm{Br}^{-}\right)$of each sample were analysed by ion chromatography and provided via the SICADA database of the Äspö HRL, as well as $\delta^{13} \mathrm{C}, \delta^{18} \mathrm{O}, \delta^{34} \mathrm{~S}$ and Tritium data.

\section{RESULTS}

\subsection{Chemical composition of investigated groundwater}

Concentrations of major cations and anions of the three investigated aquifers at Äspö are summarized in table 1 . The conductivity and the amounts of dissolved $\mathrm{Cl}, \mathrm{Br}, \mathrm{Ca}$ (Figure 2) increase with depth. Concentrations of $\mathrm{Mg}$ and alkalinity decrease with depth. Groundwater samples from TASA 1327 can be related to a groundwater of $\mathrm{Na}-\mathrm{Cl}$ Type. $\mathrm{Na}$ (ranging from 1230 to $1801 \mathrm{mg} / \mathrm{L}$ ) is the dominant cation, followed by Ca (ranging from $230-294 \mathrm{mg} / \mathrm{L}$ ). $\mathrm{Cl}$ is the dominant anion (1870 to $3082 \mathrm{mg} / \mathrm{L}$ ), followed by $\mathrm{SO}_{4}$ which ranges from 332 to $680 \mathrm{mg} / \mathrm{L}$. Most of the samples have a $\mathrm{Br} / \mathrm{Cl}$ ratio close to the signature of Baltic Seawater of 0.0034 . These groundwaters have the lowest conductivities (969 - $996 \mathrm{mS} / \mathrm{m}$ ) and the highest alkalinities (200-212 mg/L) compared to other sampling locations. 

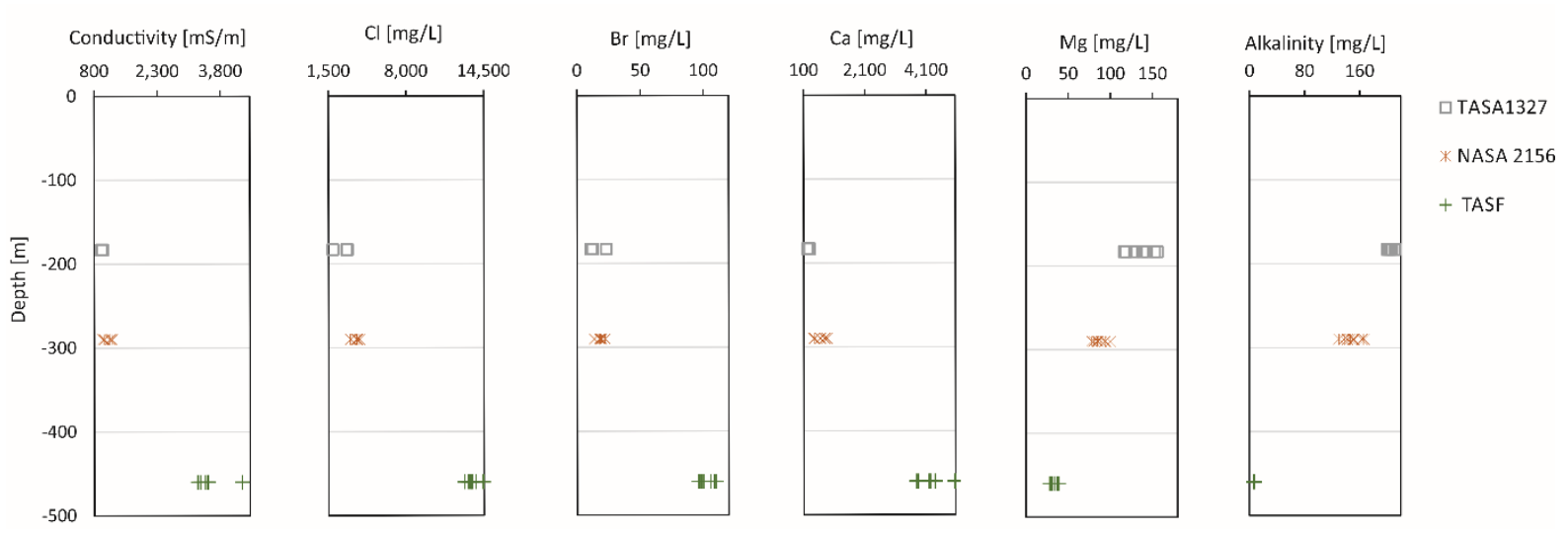

Figure 2. Relationship between conductivity, alkalinity concentration of $\mathrm{Cl}, \mathrm{Br}, \mathrm{Cl}, \mathrm{Sr}, \mathrm{Mg}$ and depth. See text for further discussion.

Groundwater samples from NASA 2156 belong to a groundwater of $\mathrm{Na}-(\mathrm{Ca})-\mathrm{Cl}$ type. The chemical composition of these groundwater samples is similar to those from TASA 1327, although higher concentrations are observed for $\mathrm{Na}(1166$ to $1801 \mathrm{mg} / \mathrm{L})$ and $\mathrm{Ca}$ (432 to 865 $\mathrm{mg} / \mathrm{L}$ ). $\mathrm{Cl}$ is the dominant anion (ranging from 3319 to $4085 \mathrm{mg} / \mathrm{L}$ ), followed by $\mathrm{SO}_{4}$ which varies from 281 to $337 \mathrm{mg} / \mathrm{L}$. The conductivity of the groundwater samples from NASA 2156 $(995-1229 \mathrm{mS} / \mathrm{m})$ is significantly higher, whereas the alkalinity $(130-166 \mathrm{mg} / \mathrm{L})$ is lower compared to those from TASA 1327.

Groundwater samples from TASF belong to groundwater of $\mathrm{Ca}-\mathrm{Na}-\mathrm{Cl}$ Type. This is the most saline aquifer with the highest concentrations for $\mathrm{Ca}, \mathrm{Na}$ and $\mathrm{Sr}$ (3767-5046 mg/L, 2757-4503 $\mathrm{mg} / \mathrm{L}$ and 57-169 $\mu \mathrm{g} / \mathrm{g}$, respectively). They contained the highest $\mathrm{Cl}$ concentrations, highest conductivities and lowest alkalinities with the values of $12860-14425 \mathrm{mg} / \mathrm{L}, 3260-4310 \mathrm{mS} / \mathrm{m}$ and 6.0-7.0 $\mathrm{mg} / \mathrm{L}$, respectively.

\subsection{Isotopic composition of groundwater and host rocks.}

Isotopic compositions of groundwater samples are presented in table 2 and 3. The isotopic abundances are expressed in per mil (\%) deviations ( $\delta$ value), which are the relative deviations from the respect standard value, defined as

$\delta=\left[\left(R_{\text {sample }} / R_{\text {standard }}\right)-1\right]{ }^{*} 1000$ 
Table 1. Chemical analyses of groundwater from TASA 1327, NASA 2156 and TASF between 2006-2010.

\begin{tabular}{|c|c|c|c|c|c|c|c|c|c|c|c|c|c|}
\hline sample & $\begin{array}{l}\text { sampling } \\
\text { date }\end{array}$ & $\mathrm{pH}$ & $\begin{array}{l}\text { conductivity } \\
{[\mathrm{mS} / \mathrm{m}]}\end{array}$ & $\begin{array}{c}\text { alkalinity } \\
{[\mathrm{mg} / \mathrm{L}]}\end{array}$ & $\begin{array}{c}\mathrm{Cl} \\
{[\mathrm{mg} / \mathrm{L}]}\end{array}$ & $\begin{array}{c}\mathrm{Br} \\
{[\mathrm{mg} / \mathrm{L}]}\end{array}$ & $\begin{array}{c}\mathrm{SO}_{4} \\
{[\mathrm{mg} / \mathrm{L}]}\end{array}$ & $\begin{array}{c}\mathbf{F} \\
{[\mathrm{mg} / \mathrm{L}]}\end{array}$ & $\begin{array}{c}\mathrm{Ca} \\
{[\mathrm{mg} / \mathrm{L}]}\end{array}$ & $\begin{array}{c}\mathrm{Na} \\
{[\mathrm{mg} / \mathrm{L}]}\end{array}$ & $\begin{array}{c}\mathrm{Mg} \\
{[\mathrm{mg} / \mathrm{L}]}\end{array}$ & $\begin{array}{c}\mathrm{K} \\
{[\mathrm{mg} / \mathrm{L}]}\end{array}$ & $\begin{array}{c}\mathrm{Mn} \\
{[\mathrm{mg} / \mathrm{L}]}\end{array}$ \\
\hline Ä3-TASA 1327 & 19.07 .2006 & 7.35 & 983 & 211.9 & 3052 & 11.1 & 332.0 & 1.5 & 282.8 & 1605.2 & 143.2 & 27.2 & 0.78 \\
\hline Ä4-TASA 1327 & 06.09 .2006 & 7.35 & 969 & 211.0 & 3056 & 23.2 & 680.0 & 1.6 & 286.4 & 1594.9 & 138.3 & 25.6 & 0.76 \\
\hline Ä5-TASA 1327 & 22.01 .2007 & 7.32 & 983 & 205.0 & 3046 & 11.5 & 345.3 & 1.6 & 294.3 & 1662.3 & 152.6 & 26.6 & 0.85 \\
\hline Ä6-TASA 1327 & 29.03.2007 & 7.29 & 978 & 207.0 & 3082 & 11.2 & 342.2 & 1.5 & 288.4 & 1632.7 & 155.7 & 25.6 & 0.79 \\
\hline Ä8-TASA 1327 & 15.04 .2008 & 7.31 & 993 & 204.3 & 3060 & 12.4 & 344.1 & 1.5 & 222.6 & 1259.7 & 118.2 & 47.3 & 0.70 \\
\hline Ä9-TASA 1327 & 13.05.2009 & 7.51 & 996 & 201.0 & 1870 & 11.7 & 350.0 & 2.0 & 247.9 & 1367.5 & 128.4 & 49.6 & 0.75 \\
\hline Ä10-TASA 1327 & 10.11.2009 & 7.31 & 977 & 199.8 & 3068 & 11.4 & 344.3 & 1.6 & 230.0 & 1230.2 & 116.5 & 46.5 & 0.71 \\
\hline Ä11-TASA 1327 & 04.03 .2010 & 7.33 & 976 & 202.0 & 3022 & 11.3 & 342.3 & 1.6 & 230.8 & 1801.1 & 118.5 & 43.1 & 0.72 \\
\hline Ä3-NASA 2156 & 19.07.2006 & 7.41 & 1173 & 137.5 & 3865 & 18.8 & 300.0 & 1.4 & 781.8 & 1637.5 & 94.2 & 12.3 & 0.59 \\
\hline Ä4-NASA 2156 & 05.09 .2006 & 7.43 & 1229 & 130.0 & 4085 & 22.2 & 337.0 & 1.5 & 864.5 & 1677.7 & 89.2 & 11.8 & 0.58 \\
\hline Ä5-NASA 2156 & 24.01 .2007 & 7.40 & 1171 & 142.0 & 3863 & 18.6 & 304.8 & 1.6 & 788.2 & 1657.6 & 93.3 & 11.6 & 0.68 \\
\hline Ä6-NASA 2156 & 28.03.2007 & 7.39 & 1178 & 146.0 & 3892 & 17.8 & 308.9 & 1.5 & 789.3 & 1629.6 & 99.9 & 11.7 & 0.63 \\
\hline Ä8-NASA 2156 & 16.04 .2008 & 7.41 & 1048 & 166.1 & 3319 & 13.7 & 293.7 & 1.5 & 431.5 & 1166.4 & 80.2 & 21.4 & 0.63 \\
\hline Ä9-NASA 2156 & 13.05.2009 & 7.55 & 995 & 152.0 & 3845 & 18.2 & 310.0 & 1.7 & 652.6 & 1350.4 & 84.7 & 24.6 & 0.66 \\
\hline Ä10-NASA 2156 & 10.11.2009 & 7.45 & 1211 & 150.1 & 3927 & 19.3 & 319.1 & 1.7 & 641.9 & 1280.4 & 78.1 & 22.8 & 0.61 \\
\hline Ä11-NASA 2156 & 03.03.2010 & 7.47 & 1028 & 163.5 & 3332 & 13.7 & 281.1 & 2.1 & 454.6 & 1801.1 & 85.3 & 20.0 & 0.70 \\
\hline Ä4-TASF & 07.09.2006 & 7.89 & 3260 & 6.3 & 12860 & 98.6 & 668.0 & 1.6 & 5046.0 & 3255.9 & 37.3 & 15.1 & 0.26 \\
\hline Ä5-TASF & 24.01 .2007 & 7.84 & 3440 & 6.0 & 13210 & 96.3 & 646.4 & 1.7 & 5027.8 & 3296.1 & 34.0 & 14.4 & 0.28 \\
\hline Ä6-TASF & 27.03.2007 & 7.74 & 3330 & 6.7 & 14425 & 98.1 & 679.3 & 1.6 & 4382.5 & 3267.7 & 38.5 & 10.6 & 0.20 \\
\hline Ä8-TASF & 15.04 .2008 & 7.93 & 3490 & 6.5 & 13456 & 108.5 & 703.2 & 1.6 & 3827.7 & 2823.9 & 29.4 & 32.9 & 0.21 \\
\hline Ä9-TASF & 13.05.2009 & 7.42 & 4310 & 6.7 & 13495 & 100.0 & 681.0 & 2.1 & 4228.4 & 3049.7 & 30.7 & 36.9 & 0.21 \\
\hline Ä10-TASF & 10.11.2009 & 7.92 & 3500 & 6.8 & 13802 & 109.6 & 699.0 & 1.7 & 3766.9 & 2757.0 & 28.2 & 32.0 & 0.21 \\
\hline Ä11-TASF & 02.03.2010 & 7.93 & 3510 & 7.0 & 13361 & 105.6 & 683.4 & 1.8 & 4193.0 & 4502.6 & 31.3 & 26.4 & 0.29 \\
\hline
\end{tabular}


Table 2. Isotopic composition $\left(\delta^{13} \mathrm{C}, \delta^{18} \mathrm{O}, \delta^{34} \mathrm{~S},{ }^{3} \mathrm{H}\right) .{ }^{*}$

\begin{tabular}{cccccc}
\hline sample & $\begin{array}{c}\text { sampling } \\
\text { date }\end{array}$ & $\boldsymbol{\delta}^{13} \mathbf{C}(\mathbf{P D B})$ & $\boldsymbol{\delta}^{18} \mathbf{O}(\mathrm{SMOW})$ & $\boldsymbol{\delta}^{34} \mathbf{S}(\mathrm{CDT})$ & ${ }^{3} \mathbf{H}(\mathrm{TU})$ \\
\hline TASA 1327 & 24.03 .2004 & -5.5 & -7.1 & 23.8 & 11.5 \\
\hline \multirow{2}{*}{ NASA 2156 } & 23.09 .2008 & -9.1 & -9 & 22.2 & 5.2 \\
& 27.09 .2007 & -7.5 & -8.7 & 21.0 & 5.6 \\
& 23.09 .2002 & & -9.2 & & 6.4 \\
\hline \multirow{2}{*}{ TASF } & 13.02 .2003 & -11.5 & -12.4 & 13.8 & b.d. \\
& 13.02 .2003 & -15.0 & -12.6 & 12.9 & b.d. \\
\hline
\end{tabular}

b.d. : below detection limit

*The data were provided by SCIDA database. 
Table 3. Strontium and Rubidium isotopic analyses of groundwater from three main aquifers, meteoric water, Baltic Sea water and rock samples.

\begin{tabular}{|c|c|c|c|c|c|c|c|c|c|}
\hline & sample & $\begin{array}{c}\text { sampling } \\
\text { date }\end{array}$ & ${ }^{87} \mathrm{Sr} / 86 \mathrm{Sr}$ & $2 \mathrm{se}$ & $\operatorname{Sr}[\mu \mathrm{g} / \mathrm{g}]$ & $1 / \mathrm{Sr}$ & $\delta^{87} \mathrm{Sr}[\% 0]$ & $\mathrm{Rb}[\mu \mathrm{g} / \mathrm{g}]$ & ${ }^{87} \mathrm{Rb} /{ }^{86} \mathrm{Sr}$ \\
\hline \multirow{8}{*}{ TASA } & Ä3-TASA 1327 & 19.07 .2006 & 0.716884 & 0.000024 & 7.06 & 0.1417 & 10.87 & & \\
\hline & Ä4-TASA 1327 & 06.09 .2006 & 0.716861 & 0.000027 & 3.47 & 0.2883 & 10.84 & & \\
\hline & Ä5-TASA 1327 & 22.01 .2007 & 0.716729 & 0.000032 & 5.06 & 0.1975 & 10.65 & & \\
\hline & Ä6-TASA 1327 & 29.03.2007 & 0.716788 & 0.000022 & 2.95 & 0.3385 & 10.74 & & \\
\hline & Ä8-TASA 1327 & 15.04 .2008 & 0.716788 & 0.000028 & 2.99 & 0.3348 & 10.74 & & \\
\hline & Ä9-TASA 1327 & 13.05.2009 & 0.716708 & 0.000036 & 4.95 & 0.2020 & 10.62 & & \\
\hline & Ä10-TASA 1327 & 10.11 .2009 & 0.716772 & 0.000028 & 5.10 & 0.1962 & 10.71 & & \\
\hline & Ä11-TASA 1327 & 04.03.2010 & 0.716765 & 0.000018 & 8.21 & 0.1218 & 10.70 & & \\
\hline \multirow{8}{*}{ NASA } & Ä3-NASA 2156 & 19.07.2006 & 0.718237 & 0.000022 & 25.03 & 0.0399 & 12.78 & & \\
\hline & Ä4-NASA 2156 & 05.09.2006 & 0.718203 & 0.000045 & 22.22 & 0.0450 & 12.73 & & \\
\hline & Ä5-NASA 2156 & 24.01.2007 & 0.718217 & 0.000019 & 19.65 & 0.0509 & 12.75 & & \\
\hline & Ä6-NASA 2156 & 28.03.2007 & 0.718143 & 0.000030 & 6.52 & 0.1534 & 12.65 & & \\
\hline & Ä8-NASA 2156 & 16.04 .2008 & 0.717856 & 0.000023 & 10.18 & 0.0982 & 12.24 & & \\
\hline & Ä9-NASA 2156 & 13.05.2009 & 0.718173 & 0.000030 & 11.68 & 0.0856 & 12.69 & & \\
\hline & Ä10-NASA 2156 & 10.11 .2009 & 0.718249 & 0.000061 & 27.63 & 0.0362 & 12.80 & & \\
\hline & Ä11-NASA 2156 & 03.03.2010 & 0.717940 & 0.000032 & 13.02 & 0.0768 & 12.36 & & \\
\hline \multirow{7}{*}{ TASF } & Ä4-TASF & 07.09 .2006 & 0.719167 & 0.000027 & 86.88 & 0.0115 & 14.09 & & \\
\hline & Ä5-TASF & 24.01.2007 & 0.719186 & 0.000012 & 75.27 & 0.0133 & 14.12 & & \\
\hline & Ä6-TASF & 27.03.2007 & 0.719174 & 0.000013 & 63.42 & 0.0158 & 14.10 & & \\
\hline & Ä8-TASF & 15.04 .2008 & 0.719201 & 0.000024 & 56.55 & 0.0177 & 14.14 & & \\
\hline & Ä9-TASF & 13.05.2009 & 0.719163 & 0.000025 & 96.23 & 0.0104 & 14.08 & & \\
\hline & Ä10-TASF & 10.11 .2009 & 0.719128 & 0.000035 & 169.34 & 0.0059 & 14.03 & & \\
\hline & Ä11-TASF & 02.03.2010 & 0.719135 & 0.000031 & 76.63 & 0.0130 & 14.04 & & \\
\hline
\end{tabular}




\begin{tabular}{|c|c|c|c|c|c|c|c|c|c|}
\hline & sample & $\begin{array}{l}\text { sampling } \\
\text { date }\end{array}$ & ${ }^{87} \mathrm{Sr} /{ }^{86} \mathrm{Sr}$ & 2 se & $\operatorname{Sr}[\mu \mathrm{g} / \mathrm{g}]$ & $1 / \mathrm{Sr}$ & $\delta^{87} \mathrm{Sr}[\%]$ & $\mathrm{Rb}[\mu \mathrm{g} / \mathrm{g}]$ & ${ }^{87} \mathrm{Rb} /{ }^{86} \mathrm{Sr}$ \\
\hline \multirow{2}{*}{ snow sample } & 1 & 04.03 .2010 & 0.718637 & 0.000040 & 0.02 & 52.1349 & 13.34 & & \\
\hline & 2 & 04.03.2010 & 0.718673 & 0.000042 & 0.02 & 51.3053 & 13.39 & & \\
\hline \multirow{2}{*}{ rain sample } & 1 & 08.05.2014 & 0.708454 & 0.000089 & 0.21 & 4.76190 & -1.02 & & \\
\hline & 2 & 08.05 .2014 & 0.708549 & 0.000053 & 0.21 & 4.76190 & -0.88 & & \\
\hline \multirow{4}{*}{ Baltic Sea } & 1 & 08.06.2010 & 0.709471 & 0.000049 & 1.30 & 0.7686 & 0.42 & & \\
\hline & 2 & 08.06.2010 & 0.709454 & 0.000024 & 1.33 & 0.7541 & 0.39 & & \\
\hline & 3 & 08.06.2010 & 0.709438 & 0.000029 & 1.22 & 0.8163 & 0.37 & & \\
\hline & 4 & 08.06.2010 & 0.709415 & 0.000030 & 1.39 & 0.7201 & 0.34 & & \\
\hline \multirow{7}{*}{ rock } & 507 & 08.04.2011 & 0.714543 & 0.000010 & 825.20 & 0.0012 & 7.57 & 143.44 & 0.50056 \\
\hline & TASA 1327 & 08.04.2011 & 0.708990 & 0.000014 & $1,182.09$ & 0.0008 & -0.26 & 97.20 & 0.23679 \\
\hline & NASA 2156-a & 08.04 .2011 & 0.708754 & 0.000012 & $1,115.21$ & 0.0009 & -0.59 & 86.41 & 0.22311 \\
\hline & NASA 2156-b & 08.04.2011 & 0.715043 & 0.000021 & 809.01 & 0.0012 & 8.27 & 148.01 & 0.52683 \\
\hline & NASA 2156-C & 08.04.2011 & 0.707124 & 0.000009 & $1,176.26$ & 0.0009 & -2.89 & 60.65 & 0.14847 \\
\hline & TASF-Host & 08.04.2011 & 0.720420 & 0.000017 & 558.74 & 0.0018 & 15.86 & 133.41 & 0.68754 \\
\hline & TASF-Epidot & 08.04.2011 & 0.706588 & 0.000021 & $4,651.45$ & 0.0002 & -3.65 & 39.56 & 0.02449 \\
\hline
\end{tabular}


$\mathrm{R}$ refer to ${ }^{13} \mathrm{C} /{ }^{12} \mathrm{C},{ }^{18} \mathrm{O} /{ }^{16} \mathrm{O},{ }^{34} \mathrm{~S} /{ }^{32} \mathrm{~S}$ and ${ }^{87} \mathrm{Sr} /{ }^{86} \mathrm{Sr}$ relative to standards $\mathrm{PDB}, \mathrm{SMOW}, \mathrm{CDT}$ and modern seawater respectively. Tritium $\left({ }^{3} \mathrm{H}\right)$ is measured in Tritium Units (TU) where $1 \mathrm{TU}$ is defined as the ratio of 1 tritium atom to $10^{18}$ hydrogen atoms.

The $\delta^{13} \mathrm{C}$ and $\delta^{18} \mathrm{O}$ are more depleted with increasing depth. $\delta^{13} \mathrm{C}$ ranged from -5.5 to -15.0 $\%$ and $\delta^{18} \mathrm{O}$ from -7.1 to $-12.6 \%$. $\delta^{34} \mathrm{~S}$ has positive values and increase with depth. The highest $\delta^{34} S\left(23.8 \%\right.$ ) was found at TASA 1327 and the lowest $\delta^{34} S(12.9 \%$ ) was found at TASF.

Highest tritium was found in TASA 1327 (11.5 TU), followed by NASA 2156 (5.2-6.4 TU) and whereas no tritium was detected in the water samples from TASF (table 2).

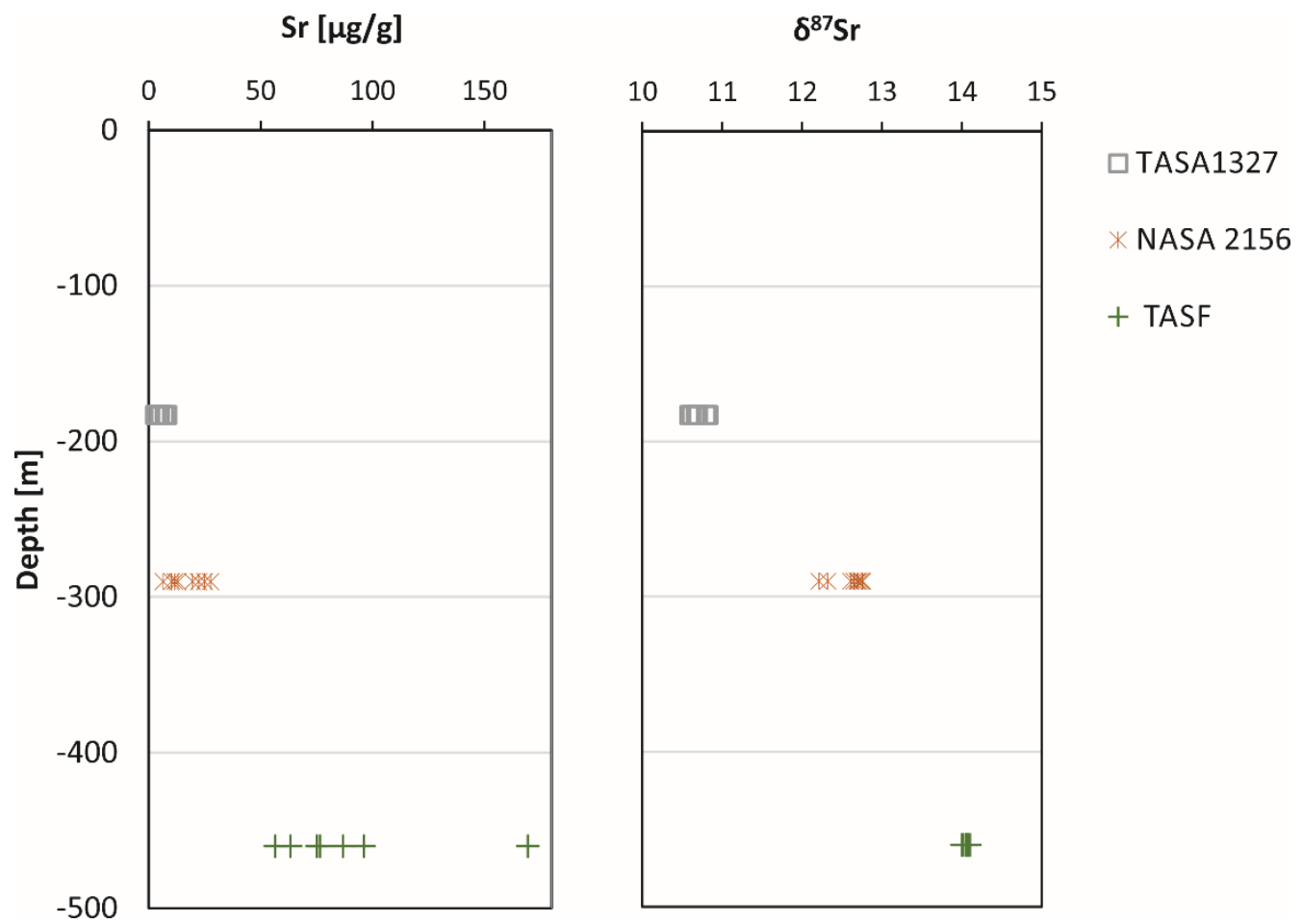

Figure 3. Relationship between $\delta^{87} \mathrm{Sr}$ and depth. $\delta^{87} \mathrm{Sr}$ increase with raising depth.

The $\delta^{87} \mathrm{Sr}$ values and Sr concentrations for the three sampling sites (TASA 1327, NASA 2156 and TASF) increase with depth (Figure 3). Each aquifer shows a specific $\delta^{87} \mathrm{Sr}$ value, which remains relatively constant over the whole sampling period with $10.73 \pm 0.08 \%$, $12.62 \pm 0.21 \%$ o and $14.09 \pm 0.04 \%$ for the TASA 1327, NASA 2156 and TASF respectively (table 3). The Sr concentrations range from 3.0 to $8.2 \mu \mathrm{g} / \mathrm{g}$ at TASA $1327,6.5-27.6 \mu \mathrm{g} / \mathrm{g}$ at NASA 2156 and $56.6-169.0 \mu \mathrm{g} / \mathrm{g}$ at TASF. The Baltic Sea water differs slightly from modern seawater standard 
with $\delta^{87} \mathrm{Sr}$ value 0.34 and low Strontium content of $1.3 \mu \mathrm{g} / \mathrm{g}$. Meteoric water sampled from rainwater shows low $\mathrm{Sr}$ concentration $(0.02 \mu \mathrm{g} / \mathrm{g})$ and a $\delta^{87} \mathrm{Sr}$ value $(-0.95 \%)$ which is significantly lower than in the Sea water samples. The collected snow sample shows the same low $\mathrm{Sr}$ concentration $(0.02 \mu \mathrm{g} / \mathrm{g})$, but a high $\delta^{87} \mathrm{Sr}$ value $(13.32 \%$ ). Although these samples were collected from fresh fallen snow and filtered before analyses a contribution of aeolian dust cannot be excluded. However, due to the extremely low Sr concentrations rain and snow do not contribute significantly to the Sr budget of the ground-water system.

In order to verify the possible end-members for water-rock interaction signatures, whole rock specimens from the same sampling localities as well as one sample from a shallow depth (507 m, Figure 1) were analysed for their Rb-Sr isotopic compositions and concentrations (table 3). Interesting is the fact that all analysed samples from the shallow depths (507, TASA 1327 and NASA 2156 a-c) plot on an isochron with a slope corresponding gives an age of $1460 \pm 24 \mathrm{Ma}$
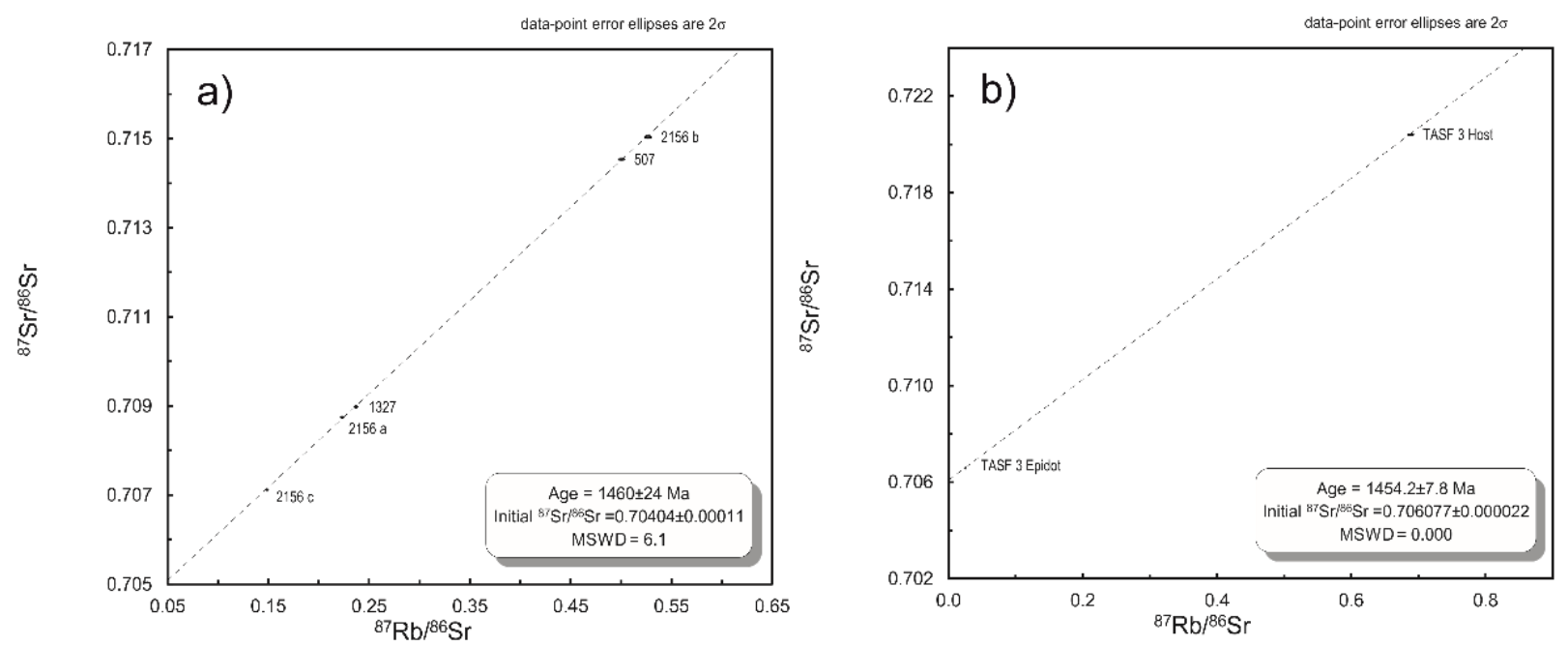

Figure 4. Rb-Sr isochron dating of the rock samples from 507, TASA 1327 and NASA 2156. all analyzed samples from the shallow depths (507, TASA 1327 and NASA 2156 a-c) plot on an isochron with a slope corresponding to an age of $1460 \pm 24 \mathrm{Ma}$ (Fig. 4a). A mineral "isochron" from the deepest site (TASF) give an age of $1454 \pm 8 \mathrm{Ma}$ (Fig. 4b). Plots are created using the programs of Ludwig (2011).

(Figure 4a). A mineral "isochron" from the deepest site (TASF) give an age of $1454 \pm 8 \mathrm{Ma}$

(Figure $4 \mathrm{~b}$ ). These ages are younger than the $1.8 \mathrm{Ga}$. assigned to the Laxemar-Simpervarp area, which is part of the Transcandinavian Igneous Belt (TIB). These young ages might well be related to later circulating fluids in open fissures and infiltrations of the bedrock in the course 
of the intrusions of the $1.45 \mathrm{Ga}$ old Götemar and Uthammar granites (Åhäll 2001). Similar effects has been described by Bachmann and Grauert (1986) and Glodny and Grauert (2009).

\subsection{Rare earth elements (REE)}
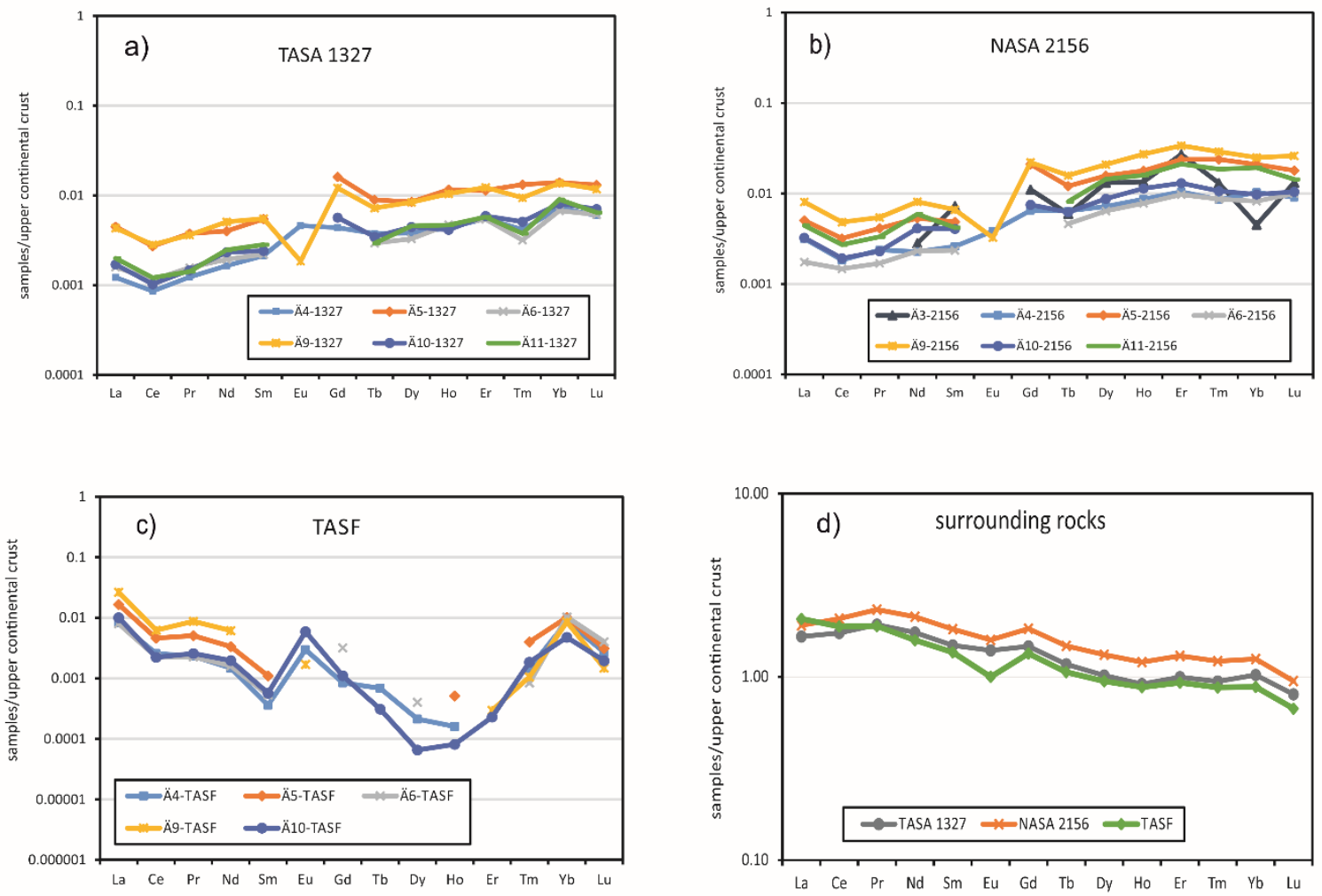

Figure 5. REE patterns for groundwater (a) TASA 1327, (b) NASA 2156, (c) TASF and (d) surrounding rocks at TASA 1327, NASA 2156 and TASF (normalized to Upper continental crust Taylor and McLennan (1985)). Groundwater samples show two different REE patterns, first an enrichment in HREE in TASA 1327 and NASA 2156 (Figure $5 \mathrm{a}, \mathrm{b}$ ) and second, an enrichment in LREE, which was found in TASF (Figure $5 \mathrm{c}$ ).

Rare earth elements abundances in groundwater samples are at TASA 1327, NASA 2156, TASF and their surrounding rock samples are shown in tables 4 and 5 . The concentrations of REE in the surrounding rock samples are above, whereas many REEs in groundwater sample are below the detection limit. The concentration is given in ppb for groundwater samples and ppm for the surrounding rock samples, respectively. For the comparison between groundwater from different aquifers and their surrounding rocks, the REE data are normalized to upper continental crust (Taylor and McLennan 1981) and plotted in logarithmic scale as shown in Figure 5. Groundwater samples show two different REE patterns, first an enrichment in heavy REE (HREE) in TASA 1327 and NASA 2156 (Figure 5a, 5b) and second, an enrichment in 
light REE (LREE), which was found in TASF (Figure 5c). The HREE enriched pattern at TASA 1327 and NASA 2156 can be caused by high alkalinity in both aquifers. Carbonate complexes are preferentially formed with HREE rather than with LREE. All surrounding rock samples show a similar pattern with enriched LREE (Figure $5 \mathrm{~d}$ ), which is also similar to the pattern observed for the groundwater samples in TASF. 
Table 4. ICP-MS analysis of groundwater samples. All concentrations are in ppb.

\begin{tabular}{ccccccccc}
\hline samples & Ä3-1327 & $\ddot{A} 4-1327$ & Ä5-1327 & Ä6-1327 & Ä8-1327 & Ä9-1327 & Ä10-1327 & Ä11-1327 \\
\hline La & b.d. & 0.037 & 0.134 & 0.048 & 2.828 & 0.130 & 0.051 & 0.060 \\
$\mathrm{Ce}$ & b.d. & 0.051 & 0.163 & 0.069 & 2.416 & 0.170 & 0.062 & 0.073 \\
$\mathrm{Pr}$ & b.d. & 0.008 & 0.025 & 0.011 & 0.391 & 0.024 & 0.010 & 0.010 \\
$\mathrm{Nd}$ & 0.006 & 0.044 & 0.108 & 0.052 & 1.106 & 0.137 & 0.063 & 0.067 \\
$\mathrm{Sm}$ & 0.013 & 0.011 & 0.029 & 0.012 & 0.356 & 0.029 & 0.013 & 0.015 \\
$\mathrm{Eu}$ & b.d. & 0.006 & b.d. & b.d. & 0.137 & 0.002 & b.d. & b.d. \\
$\mathrm{Gd}$ & 0.009 & 0.017 & 0.064 & b.d. & 0.297 & 0.048 & 0.023 & b.d. \\
$\mathrm{Tb}$ & b.d. & 0.002 & 0.006 & 0.002 & 0.117 & 0.005 & 0.002 & 0.002 \\
$\mathrm{Dy}$ & 0.007 & 0.014 & 0.032 & 0.012 & 0.334 & 0.032 & 0.017 & 0.017 \\
$\mathrm{Ho}$ & b.d. & 0.003 & 0.009 & 0.004 & 0.103 & 0.008 & 0.003 & 0.004 \\
$\mathrm{Er}$ & 0.013 & 0.012 & 0.024 & 0.011 & 0.169 & 0.026 & 0.012 & 0.012 \\
$\mathrm{Tm}$ & b.d. & 0.001 & 0.004 & 0.001 & 0.028 & 0.003 & 0.002 & 0.001 \\
$\mathrm{Yb}$ & b.d. & 0.015 & 0.028 & 0.014 & 0.210 & 0.027 & 0.016 & 0.018 \\
$\mathrm{Lu}$ & b.d. & 0.002 & 0.005 & 0.002 & 0.041 & 0.004 & 0.002 & 0.002 \\
\hline
\end{tabular}

\begin{tabular}{ccccccccc}
\hline samples & Ä3-2156 & Ä4-2156 & Ä5-2156 & Ä6-2156 & Ä8-2156 & Ä9-2156 & Ä10-2156 & Ä11-2156 \\
\hline La & b.d. & 0.095 & 0.151 & 0.052 & 1.043 & 0.243 & 0.098 & 0.133 \\
$\mathrm{Ce}$ & b.d. & 0.110 & 0.192 & 0.089 & 1.070 & 0.290 & 0.115 & 0.163 \\
$\mathrm{Pr}$ & b.d. & 0.016 & 0.028 & 0.011 & 0.150 & 0.036 & 0.015 & 0.022 \\
$\mathrm{Nd}$ & 0.076 & 0.061 & 0.144 & 0.062 & 0.615 & 0.219 & 0.111 & 0.160 \\
$\mathrm{Sm}$ & 0.038 & 0.014 & 0.026 & 0.012 & 0.163 & 0.035 & 0.022 & 0.022 \\
$\mathrm{Eu}$ & b.d. & 0.005 & b.d. & b.d. & 0.068 & 0.004 & b.d. & b.d. \\
$\mathrm{Gd}$ & 0.044 & 0.026 & 0.084 & b.d. & 0.175 & 0.088 & 0.030 & b.d. \\
$\mathrm{Tb}$ & 0.004 & 0.004 & 0.008 & 0.003 & 0.027 & 0.010 & 0.004 & 0.005 \\
$\mathrm{Dy}$ & 0.050 & 0.027 & 0.060 & 0.024 & 0.204 & 0.079 & 0.033 & 0.055 \\
$\mathrm{Ho}$ & 0.011 & 0.007 & 0.014 & 0.006 & 0.037 & 0.022 & 0.009 & 0.013 \\
$\mathrm{Er}$ & 0.057 & 0.022 & 0.050 & 0.020 & 0.040 & 0.071 & 0.027 & 0.044 \\
$\mathrm{Tm}$ & 0.004 & 0.003 & 0.007 & 0.003 & 0.001 & 0.009 & 0.003 & 0.006 \\
$\mathrm{Yb}$ & 0.009 & 0.021 & 0.042 & 0.016 & 0.167 & 0.050 & 0.020 & 0.039 \\
$\mathrm{Lu}$ & 0.005 & 0.003 & 0.006 & 0.003 & 0.030 & 0.009 & 0.004 & 0.005 \\
\hline
\end{tabular}




\begin{tabular}{cccccccc}
\hline samples & Ä4-TASF & Ä5-TASF & Ä6-TASF & Ä8-TASF & Ä9-TASF & Ä10-TASF & Ä11-TASF \\
\hline La & 0.248 & 0.496 & 0.240 & 1.902 & 0.793 & 0.301 & 0.107 \\
$\mathrm{Ce}$ & 0.155 & 0.277 & 0.136 & 1.513 & 0.375 & 0.133 & 0.053 \\
$\mathrm{Pr}$ & 0.016 & 0.034 & 0.015 & 0.205 & 0.058 & 0.017 & 0.003 \\
$\mathrm{Nd}$ & 0.040 & 0.090 & 0.043 & 0.740 & 0.166 & 0.053 & 0.024 \\
$\mathrm{Sm}$ & 0.002 & 0.006 & 0.003 & 0.165 & b.d. & 0.003 & 0.002 \\
$\mathrm{Eu}$ & 0.004 & b.d. & b.d. & 0.091 & 0.002 & 0.008 & b.d. \\
$\mathrm{Gd}$ & 0.003 & b.d. & 0.013 & 0.152 & b.d. & 0.004 & 0.003 \\
$\mathrm{~Tb}$ & b.d. & b.d. & b.d. & 0.043 & b.d. & b.d. & b.d. \\
$\mathrm{Dy}$ & 0.001 & b.d. & 0.002 & 0.157 & b.d. & b.d. & b.d. \\
$\mathrm{Ho}$ & b.d. & b.d. & b.d. & 0.030 & b.d. & b.d. & b.d. \\
$\mathrm{Er}$ & b.d. & b.d. & b.d. & b.d. & 0.001 & b.d. & b.d. \\
$\mathrm{Tm}$ & b.d. & 0.001 & b.d. & 0.003 & b.d. & 0.001 & 0.003 \\
$\mathrm{Yb}$ & 0.017 & 0.020 & 0.021 & 0.128 & 0.017 & 0.009 & 0.002 \\
$\mathrm{Lu}$ & 0.001 & 0.001 & 0.001 & 0.024 & 0.001 & 0.001 & b.d. \\
\hline
\end{tabular}

b.d. : below detection limit

Table 5. ICP-MS analysis of surrounding rock samples. All concentrations are in ppm.

\begin{tabular}{cccc}
\hline samples & TASA 1327 & NASA 2156 & TASF \\
\hline $\mathrm{Na}$ & 23400 & 25400 & 17500 \\
$\mathrm{Mg}$ & 9250 & 11400 & 5290 \\
$\mathrm{~K}$ & 18000 & 13350 & 29700 \\
$\mathrm{Ca}$ & 10800 & 12200 & 5400 \\
$\mathrm{Fe}$ & 22800 & 27300 & 18700 \\
$\mathrm{Mn}$ & 543 & 502 & 346 \\
$\mathrm{La}$ & 49.70 & 57.30 & 62.20 \\
$\mathrm{Ce}$ & 104.00 & 124.50 & 113.00 \\
$\mathrm{Pr}$ & 12.90 & 15.60 & 12.70 \\
$\mathrm{Nd}$ & 47.10 & 57.40 & 42.80 \\
$\mathrm{Sm}$ & 7.88 & 9.66 & 7.22 \\
$\mathrm{Eu}$ & 1.81 & 2.07 & 1.30 \\
$\mathrm{Gd}$ & 5.87 & 7.34 & 5.37 \\
$\mathrm{~Tb}$ & 0.76 & 0.96 & 0.69 \\
$\mathrm{Dy}$ & 3.87 & 5.03 & 3.60 \\
$\mathrm{Ho}$ & 0.73 & 0.96 & 0.70 \\
$\mathrm{Er}$ & 2.09 & 2.74 & 1.95 \\
$\mathrm{Tm}$ & 0.28 & 0.37 & 0.26 \\
$\mathrm{Yb}$ & 2.05 & 2.50 & 1.76 \\
$\mathrm{Lu}$ & 0.28 & 0.33 & 0.24 \\
\hline
\end{tabular}




\section{DISCUSSION}

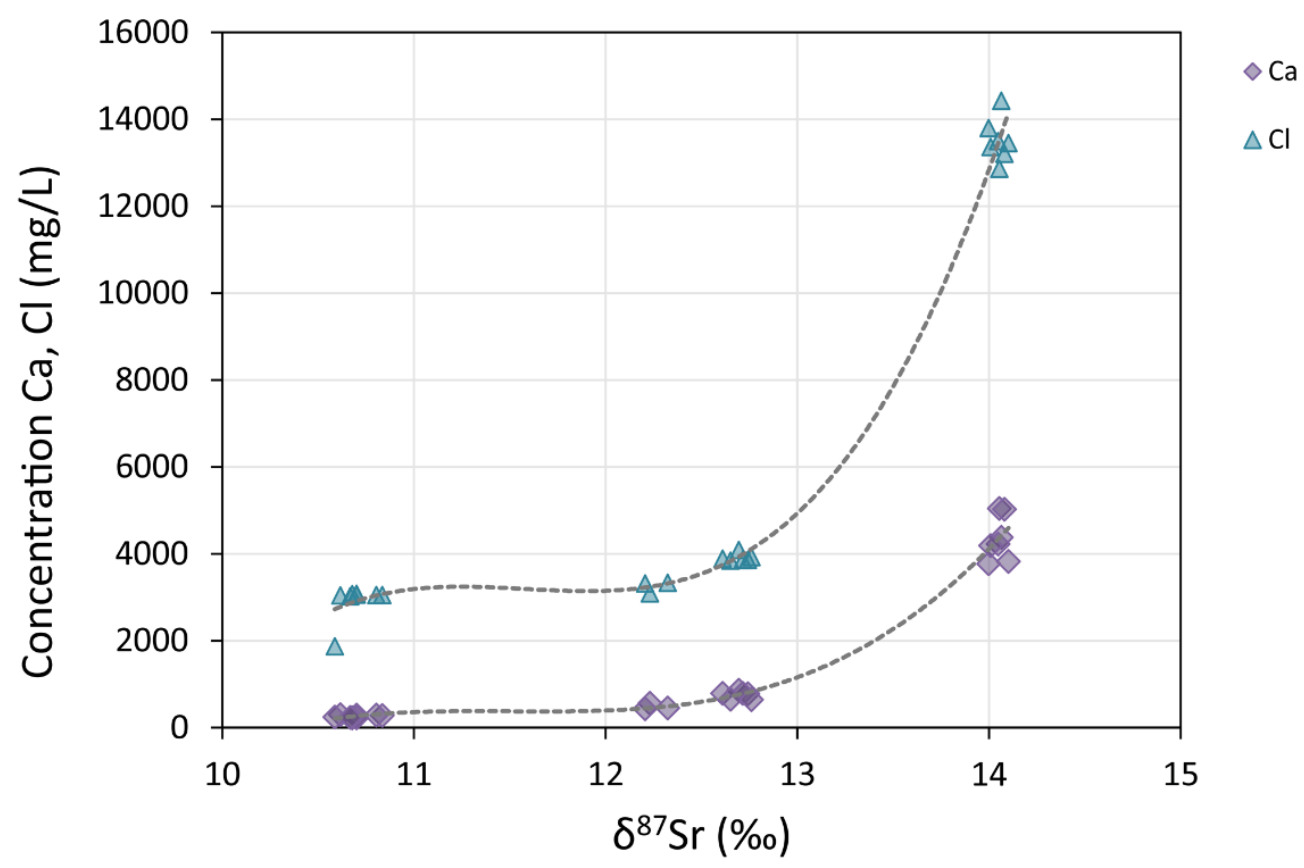

Figure 6. Correlation between $\delta^{87} \mathrm{Sr}$ and $\mathrm{Ca}, \mathrm{Cl}$ concentration in Äspö groundwater, which shows the trends of a third order polynomial and indicates the mixing of more than two components.

The isotopic and chemical compositions of the groundwaters from all sampling stations show minor variations during the investigated period. In long-term aspects a systematic trend of these variations has not been noticed. All aquifers have rather stable and unique isotopic and chemical value ranges, which can be used to differentiate among the respective aquifers. The trend of increasing salinity with depth may be interpreted as a two component mixing between non-saline and saline groundwater (Laaksoharju et al. 1999). However, the relationship between $\mathrm{Sr}$ isotope variations and major elements such as $\mathrm{Cl}$ and $\mathrm{Ca}$ can be used as a proof for the binary mixing of two components, in which linear mixing trends should be found. In figure 6 the correlation between $\delta^{87} \mathrm{Sr}$ and $\mathrm{Ca}, \mathrm{Cl}$ show the trends of a third order polynomial and this indicates the mixing of more than two components.

This fact is also confirmed by $\delta^{87} \mathrm{Sr}$ values plotted against $1 / \mathrm{Sr}$ (Figure 7 ). The hypothetical mixing line for binary mixing would have a linear trend connecting the end members. Our data do not follow a linear trend between the most saline groundwater with the maximum $\delta^{87} \mathrm{Sr}$ 
value sample and the Baltic Sea sample. The scattering data point to the mixing with at least a third or more end members. The abundance of the Baltic Sea component in each groundwater sample can be calculated by equation

$$
\mathrm{f}_{\mathrm{A}}=\frac{\delta^{87} \mathrm{Sr}_{\text {sample }}-\delta^{87} \mathrm{Sr}_{\mathrm{B}} \frac{\mathrm{Sr}_{\mathrm{B}}}{\mathrm{Sr}_{\text {sample }}}}{\delta^{87} \mathrm{Sr}_{\mathrm{A}} \frac{\mathrm{Sr}_{\mathrm{A}}}{\mathrm{Sr}_{\text {sample }}}-\delta^{87} \operatorname{Sr}_{\mathrm{B}} \frac{\mathrm{Sr}_{\mathrm{B}}}{\operatorname{Sr}_{\text {sample }}}}
$$

Subscripts A, B refer to Baltic Sea water and high saline groundwater respectively.

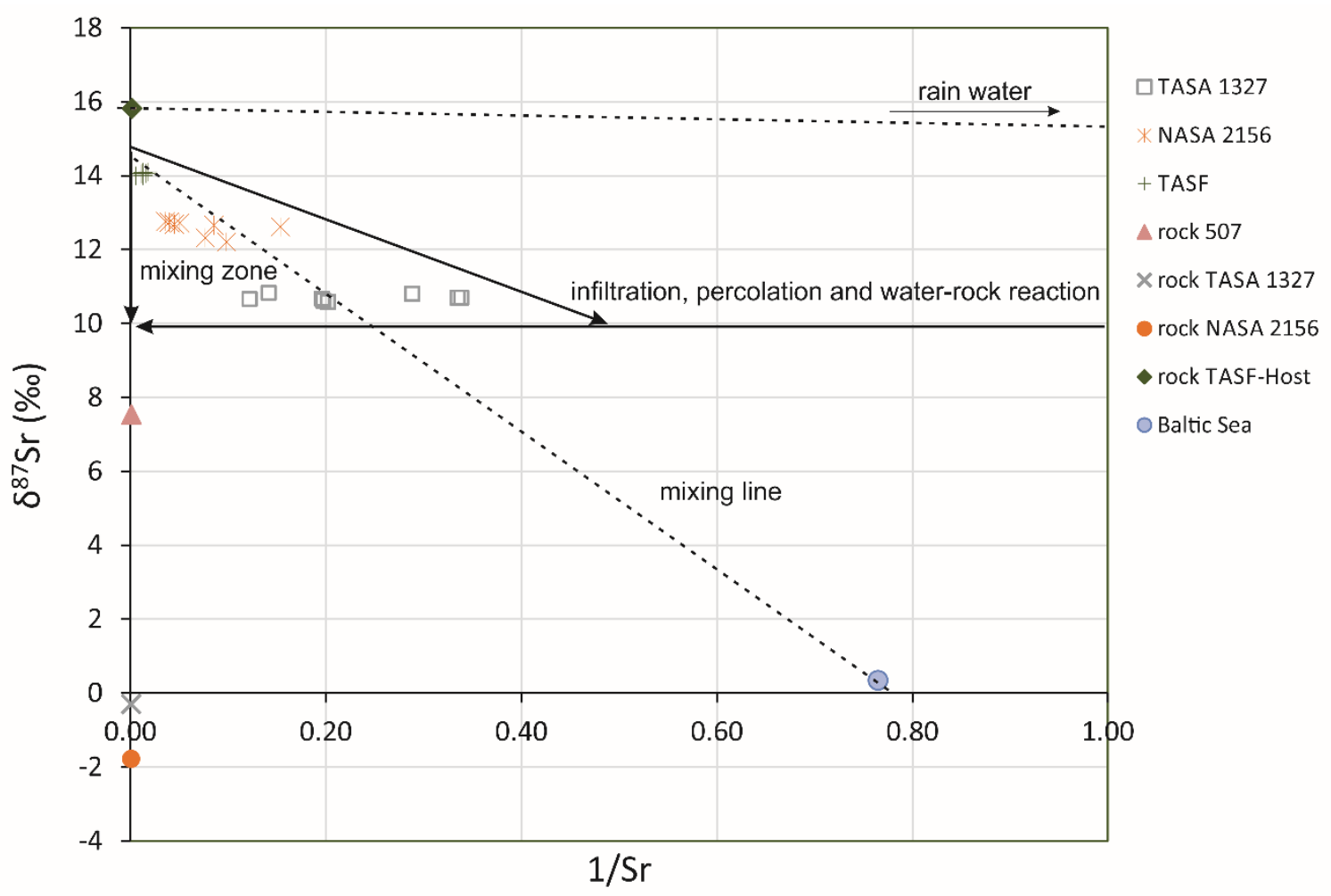

Figure 7. Correlation between $\delta^{87} \mathrm{Sr}$ and $1 / \mathrm{Sr}$. The hypothetical mixing line for binary mixing would have a linear trend connecting the end members. This data set does not follow a linear trend between the most saline groundwater with the maximum $\delta^{87} \mathrm{Sr}$ value sample and the Baltic Sea sample. The scattering data point to the mixing with at least a third or more end members. Relationship between $\delta^{87} \mathrm{Sr}$ and $1 / \mathrm{Sr}$ of groundwater samples in TASA 1327, NASA 2156, TASF and their host rock samples. The $\delta^{87} \mathrm{Sr}$ values for the host rocks at TASA $1327(-0.3 \% 0)$ and NASA $2156(-1.7 \%)$ do not overlap with values from the adjacent groundwater samples. Whereas the TASF groundwater samples show ${ }^{87} \mathrm{Sr} /{ }^{86} \mathrm{Sr}$ ratios, which correlate well with the one observed for the host rock. (modified after Peterman \& Wallin 1999).

In case of a simple mixing the groundwater samples by TASA 1327 with a mean ${ }^{87} \mathrm{Sr}$ value of $10.7 \%$ may contain $96 \%$ Baltic Sea water component and by NASA $215683 \%$ with a mean $\delta^{87} \mathrm{Sr}$ value of $12.6 \%$. Furthermore, due to the large deviation from the hypothetical 
mixing line the groundwater samples in TASA 1327 and NASA 2156 tend to be more effected from the additional end member components than those in TASF.

In figure 7 mean values of Sr deviations against reciprocal Sr concentration of groundwater samples and their surrounding rocks are plotted. The $\delta^{87} \mathrm{Sr}$ values for the host rocks at TASA $1327(-0.3 \%)$ and NASA $2156(-1.7 \%$ o) do not overlap with values from the adjacent groundwater samples. This means that these groundwaters are not in equilibrium with the rock, in which they reside. This can be caused by deficient residence time and relative high flow rate of groundwater in these aquifers. To establish an equilibrium phase between a groundwater aquifer and the surrounding rocks sufficient time is needed. The different fractionation patterns of groundwater at TASA 1327, NASA 2156 and their surrounding rocks provide an evidence for a non-chemical equilibrium.

The TASF groundwater samples show ${ }^{87} \mathrm{Sr} /{ }^{86} \mathrm{Sr}$ ratios, which are only slightly lower than the one observed for the host rock. Furthermore, the groundwater in TASF exhibits a LREE enriched pattern like the one of the surrounding rocks. This might indicate that a long term groundwater-rock interaction for this aquifer could have taken place, but a coincidence of composition of fluid and whole rock cannot be excluded.

The high concentration of ${ }^{87} \mathrm{Sr}$ in TASF can be caused by the different content of K-rich minerals, as the $\mathrm{K}$ can be substituted by $\mathrm{Rb}$ which decays to radiogenic ${ }^{87} \mathrm{Sr}$. The ICP-MS Analyses of surrounding rock samples at TASA 1327 and NASA 2156 show significantly lower concentration of $\mathrm{K}$ (18000 and $13350 \mathrm{ppm}$, respectively) than that in the TASF (29700 ppm) and therefore lower ${ }^{87} \mathrm{Sr} /{ }^{86} \mathrm{Sr}$ ratio.

\subsection{Shallow groundwater at TASA 1327}

These groundwater samples show $\mathrm{Br} / \mathrm{Cl}$ ratios and $\mathrm{Cl}$ concentrations, which are close to the values of marine water $\left(3.40^{*} 10^{-3}\right.$ and $3760 \mathrm{mg} / \mathrm{L}$ respectively), thus also indicating the Baltic Sea water chemistry as an end member composition. The $\delta^{34} S$ value of $23.8 \%$ is close to that of the modern sea water $(20 \%)$. Slightly higher $\delta^{34} S$ value than Baltic Sea and low concentration of sulfate are presumably caused by bacterial sulfate reduction, where the light 
sulfur isotope $\left({ }^{32} \mathrm{~S}\right)$ is favored over the heavy isotope $\left({ }^{34} \mathrm{~S}\right)$ during metabolism, leading to an enrichment of ${ }^{34} \mathrm{~S}$ in dissolved sulfate in groundwater (Drake et al. 2013). Indeed microbial activity, also by sulfate reducing bacteria (SRB) has been observed in this aquifer (lonescu et al. accepted, this issue). The $\delta^{13} \mathrm{C}$ value $(-5.5 \%$ of dissolved carbonate in the groundwater is indicative for a freshwater carbonate signature and high tritium concentration (11.5 TU) indicating modern meteoric recharge within a year to decades percolating through the fracture zones. Furthermore, the $\delta^{18} \mathrm{O}$ value and high alkalinities also point to a mixing of recharged meteoric water. Although models estimated a maximum penetration depth of $100-150 \mathrm{~m}$ for meteoric water at the Äspö site (Wallin et al. 2007), the observed $\delta^{18} \mathrm{O}$ value of $-7.1 \%$ may be indicative for a mixture of Baltic Sea water $(-5.9 \%)$ and the meteoric water $(-10.5 \%$; Wallin et al. 2007; Laaksoharju et al. 2009), this is also valid for the Sr isotopic composition in the host rock (table 3).

\subsection{Intermediate groundwater at NASA 2156}

Intermediate groundwaters at NASA 2156 are characterized by a mixture of Baltic Sea water and meteoric water, but to a smaller proportion than in samples from TASA 1327. Although the water chemistry is similar, the isotopic composition of the groundwater at NASA 2156 differs significantly from the groundwater at TASA 1327 , with a mean $\delta{ }^{87} \mathrm{Sr}$ ratio of $12.6 \%$ and higher $\mathrm{Sr}$ concentrations. The $\delta^{34} \mathrm{~S}$ values of $21.0-22.2 \%$ is very close to that of the modern sea water but lower than that in TASA 1327. Although less abundant, but activity of SRB has also been described for NASA 2156 . The observed $\delta^{18} \mathrm{O}$ value of $-9 \%$ may also derive from significant input of meteoric water. Tritium content of 5.2 TU suggests a mixing of sub-modern and modern water recharge, which has a longer residence time than the water in TASA 1327.

\subsection{Deep groundwater at TASF}

Deep groundwaters at TASF are characterized by a saline groundwater and a glacial component from the last deglaciation, which are high in $\mathrm{Cl}$ concentration $(>12,000 \mathrm{mg} / \mathrm{L})$, tritium free and showing a depleted $\delta^{18} \mathrm{O}$ signature $(-12.0 \%)$. Tritium free groundwater 
provides evidence, that groundwater at TASF is not connected with the other modern recharged groundwater sources. The low $\delta^{18} \mathrm{O}$ value is an indicator of a cold climate recharge component (Smellie et al. 1995; Laaksoharju 1999). The lower value of $\delta^{34} S(12.9-13.8 \%$ o) may be due to dissolution of ${ }^{34}$ S-depleted sulfate (4-13\%) from Paleozoic gypsum in this aquifer, therefore microbial sulfate reduction can be masked by high sulfate concentrations in this aquifer (Drake et al. 2013). Indeed, activity of SRB and other bacteria have been described for this aquifers and others in similar depths (Hallbeck and Pedersen 2012; Ionescu et al. 2015). The ${ }^{87} \mathrm{Sr} /{ }^{86} \mathrm{Sr}$ ratios of the present-day groundwaters $(0.71913-0.71920)$ are similar to that of the host rock in this aquifer (0.72042). The relative high amount of ${ }^{87} \mathrm{Sr}$ can be caused by the composition of the $\mathrm{Rb}$ or $\mathrm{K}$ - rich minerals in the host rock. Rb substitutes readily for $\mathrm{K}$ in many minerals, decays in radiogenic ${ }^{87} \mathrm{Sr}$ and is released in the water by weathering and ion-exchange. This observation is in agreement with pubished Sr isotope data of Äspö groundwaters (Peterman \& Wallin 1999). Although element-leaching processes may vary with the minerals involved, water-rock interaction might also be observed from REE-data. The groundwater in TASF exhibits the LREE enriched pattern like the one of the surrounding rocks. This pattern was not observed in TASA 1327 and NASA 2156, in which the residence time of groundwater is much shorter than in TASF.

\section{CONCLUSION}

The isotopic and chemical composition of groundwater in each aquifer has not changed significantly from 2006-2010. The concentration of Strontium increased with depth and all aquifers show a specific ${ }^{87} \mathrm{Sr} /{ }^{86} \mathrm{Sr}$ signature with $0.71679 \pm 0.00006,0.71813 \pm 0.00015$ and $0.71917 \pm 0.00003$ for TASA 1327, NASA 2156 and TASF, respectively. Age information from small-scale Sr homogenization suggest that the pegmatitic filling of the fractures is related to the nearby intrusion of the Götemar granite $(1.45 \mathrm{Ga})$. The analyses of Sr-data and rare earth element (REE) show indications of long term groundwater-rock interaction in the TASF aquifer. Highest influence of Baltic Sea water was found in the TASA 1327 aquifer. The nonlinear correlations between $\delta^{87} \mathrm{Sr}$ values and $\mathrm{Ca}$ and $\mathrm{Cl}$ concentrations suggest the influence of more 
than two components in the groundwater system at Äspö. The stable isotopes and the chemical data from the three main aquifers show distinct patterns: Shallow groundwater aquifer (TASA 1327) indicates the mixture of Baltic Sea water and meteoric water. Intermediate aquifer (NASA 2156) consists of Baltic Sea water and meteoric water as dominant components similar to the groundwater at TASA 1327 but longer residence time. The deep aquifer (TASF) is characterized by saline groundwater and last glacial meltwater, which was hydraulically penetrated into the bedrock.

\section{ACKNOWLEDGEMENTS}

The authors wish to thank the Swedish Nuclear Fuel and Waste Management Company (SKB) for logistic support, providing access to the SICADA database and for chemical analyses at the Äspö Hard Rock Laboratory. We wish to thank B. Dietrich and F. Wilsky for their help with the $\mathrm{Rb}-\mathrm{Sr}$ analyses. Careful and constructive reviews by J. Glodny and an anonymous reviewer are gratefully acknowledged. This work was financed by the German Research Foundation (DFG) and is publication no. XX of the DFG Research Unit FOR 571 (Geobiology of Organo- and Biofilms).

\section{REFERENCES}

Amend JP, Teske A. 2005. Expanding frontiers in deep subsurface microbiology. Palaeogeography, Palaeoclimatology, Palaeoecology 219: 131-155.

Åhäll KI. 2001. Åldersbestämning av svårdaterade bergarter I sydöstra Sverige. SKB R-0893. Svensk Kärnbränslehantering AB.

Bachmann G, Grauert B. 1986. Altersbestimmung mit ${ }^{87} \mathrm{Sr} /{ }^{86} \mathrm{Sr}$ - Ungleichgewichtsverteilung. Fortshr. D Mineral 64 Beih 1:12.

Banwart S, Tullborg, EL, Pederson K, Gustafsson E, Laaksoharju M, Nilsson AC, Wallin B, Wikberg P. 1996. Organic carbon oxidation induced by large-scale shallow water intrusion into a vertical fracture zone at the Äspö Hard rock Laboratory (Sweden). Journal of Contaminat Hydrology 21: 115-125.

Clark ID, Fritz P. 1954. Environmental Isotopes in Hydrogeology. USA: CRC Press. 328 p.

Craig H. 1961. Isotopic variations in meteoric waters. Science 133: 1702-1703. 
Dobretsov NL, Kolchanov NA, Suslov VV. 2006. On the early stages of the evolution of the geosphere and biosphere. Paleontological Journal 40:407-424.

Drake H, Åström ME, Tullborg EL, Whitehouse M, Fallick AE. 2013. Variability of sulphur isotope ratios in pyrite and dissolved sulphate in granitoid fractures down to $1 \mathrm{~km}$ depthEvidence for widespread activity of sulphur reducing bacteria. Geochimica et Cosmochimica Acta 102:143-161.

Faure G, Mensing TM. 2005. Isotope Principle and Applications $3^{\text {rd }}$ Ed. New Jersey: John Wiley \& Sons, Inc. 897p.

Fritz P, Lodemann M, Weise S, Wolf M, Behr HJ, Hansen BT, Horn EE, Reutel Chr, Topp J, Pekdeger A, Hein-Schild HJ, Kamm H, Merz S, Wittenbecher M, Nolte E, Korschnik G, Duckhorn. 1991. Saline Fluids in the KTB Pilot Borehole. Scientific Drilling 2: 231-243

Glodny J, Grauert B. 2009. Evolution of a hydrothermal fluid-rock interaction system as recorded by Sr isotopes: A casee study from the Schwarzwald, SW Germany. Mineralogy and Petrology 95(3-4): 163-178

Gosselin DC, Harvey FE, Frost C, Stotler R, Macfarlane PA. 2004. Strontium isotope geochemistry of groundwater in the central part of the Dakota (Great Plains) aquifer, USA. Applied Geochemistry 19: 359-377.

Hallbeck L, Pedersen K. 2012. Culture-dependent comparison of microbial diversity in deep granitic groundwater from two sites considered for a Swedish final repository of spent nuclear fuel. FEMS Microbiology Ecolology 81: 66-77.

Ionescu D, Heim C, Polerecky L, Ramette A, Haeusler S, Bizic-lonescu M, Thiel V, De Beer D. 2015. Diversity of iron oxidizing and reducing bacteria in flow reactors in the Äspö Hard Rock Laboratory. Geomicrobiology Journal 42 (2-3): 207-220.

Johansson H, Siitari-Kauppi M. Skalberg M, Tullbort EL. 1998. Diffusion pathways in crystalline rock - examples from Äspö-diorite and fine-grained granite. Journal of Contaminant Hydrology 35: 41-53.

Kaplan IR, Rittenberg SC. 1964. Microbiological fractionation of sulphur isotopes. J. Gen. Microbiology 34: 195-212.

Kendall C and McDonnell JJ. 1998. Elsevier Science BV, Amsterdam, 839 p.

Klaus JS, Hansen BT, Buapeng S. $2007 .{ }^{87} \mathrm{Sr} /{ }^{86} \mathrm{Sr}$-Ratios: A Natural Tracer to characterize the Groundwater of Bangkok Area, Thailand, with respect to Public Water Supply and Freshwater Reinjection. Hydrogeology Journal 15: 745-758.

Laaksoharju M, Tullborg EL, Wikberg P, Wallin B, Smellie J. 1999. Hydrogeochemical conditions and evolution at the Äspö HRL, Sweden. Applied Geochemistry 14: 835-859.

Laaksoharju M, Smellie J, Tullborg EL, Wallin B, Drake H, Gascoyne M, Gimeno M, Gurban I, Hallbeck L, Morlinero J, Nilsson AC, Waber Nick. 2009. Bedrock hydrogeochemistry Laxemar. SKB R-08-93. Svensk Kärnbränslehantering AB. 
Ludwig KR. 2011. A geochronological toolkit for Microsoft Exel. Berkley Geochronology Centre, Special Publications. Version 4.1.

Mansfeld J. 1996. Geological, geochemical and geochronological evidence for a new Palaeoproterozoic terrane in southeastern Sweden. Precambrian Research 77: 91-103.

Mansfeld J, Beunk FF, Barling J. 2005. 1.83-1.82 Ga formation of a juvenile volcanic arc implications from U-Pb and $\mathrm{Sm}-\mathrm{Nd}$ analyses of the Oskarshamn-Jonkoping Belt, southeastern Sweden. Geologiska Foreningens i Stockholm Forhandlingar 127: 149-157.

McArthur JM, Howarth RJ, Shields GA. 2012. Strontium isotope stratigraphy. In: Gradstein FM, Ogg JG, Schmitz M, Ogg G, Eds. The geologic time scale 2012. Amsterdam: Elsevier. P 127-144.

Mc Crea JM. 1950. On the isotopic chemistry of carbonates and a paleotemperature scale. J Chem Phys 18: 849-857.

Möller P, Weise S, Althaus E, Bach W, Behr HJ, Borchardt R, Bräuer K, Drescher J, Erzinger J, Faber E, Hansen BT, Horn EE, Huenges E, Kämpf H, Kessels W, Kirsten T, Landwehr D, Lodemann M, Machon L, Peck-Decker A, Pielow HU, Reutel Chr, Simon KJ, Weinlich FH, Zimmer M. 1997. Paleo- and Recent fluids in the Upper Continental Crust. Results from the German Continental Deep Drilling Project (KTB). J. Geophys. Res. 102 (B8): 18233-18254.

Pedersen K. 2000. Exploration of deep intraterrestrial microbial life: current perspectives. FEMS. Microbiology Letters 185: 9-16.

Peterman ZE, Wallin B. 1999. Synopsis of Strontium isotope variations in groundwater at Äspö, southern Sweden. Applied Geochemistry 14: 939-951.

Sim MS, Bosak T, Ono S. 2011. Large sulfur isotope fractionation does not require disproportionation. Science 333: 74-77.

Smellie JAT, Laaksoharju M, Wikberg P. 1995. Äspö, SE Sweden: a natural groundwater flow model derived from hydrogeochemical observations. Journal of Hydrology 172: 147-169.

Taylor SR, McLennan SM. 1981. The composition and evolution of the continental crust: rare earth element evidence from sedimentary rocks. Phil. Trans. R. Soc. A301: 381-399.

Tütken T, Eisenhauer A, Wiegand B, Hansen BT. 2002. Glacial-interglacial cycles in Sr and $\mathrm{Nd}$ isotopic composition of Artic marine sediments: changes in sediment provenance triggered by the Barents Sea ice sheet. Marine Geology 182: 351-372.

Wallin B, Peterman Z. 1999. Calcite fracture fillings as indicators of paleohydrology at Laxemar at the Äspö Hard Rock Laboratory, southern Sweden. Applied Geochemistry 14:953-962. Wallin B, Laaksohaarju M, Tullborg EL. 2007. Description of the different end-members identified from interpretations of groundwater chemistry and mixing models; results from Äspö and Laxemar area. SKB R-08-74. Svensk Kärnbränslehantering AB. 
Wiegand B, Dietzel M, Bielert U, Groth P, Hansen BT. 2001. ${ }^{87} \mathrm{Sr} /{ }^{86} \mathrm{Sr}$-Verhältnisse als Tracer für hydrochemische Prozesse in einem Lockergesteinsaquifer (Libenau, NWDeutschland). Acta. Hydrochem. Hydrobiol. 29(2-3): 139-152. 


\title{
CHAPTER 4
}

\section{Manuscript III: Geochemical Characteristics and Origin of $\mathrm{CO}_{2}$-rich Groundwater in Southern Thailand}

\author{
Manussawee Hengsuwan ${ }^{1,2^{\star}}$, Helmut Dürrast ${ }^{3}$, Bent T. Hansen ${ }^{1}$
}

${ }^{1}$ Geoscience Center Göttingen, University of Göttingen, Goldschmidtstr. 1-3, 37077, Göttingen, Germany

${ }^{2}$ Department of Groundwater Resources, Bangkok, Thailand

${ }^{3}$ Geophysics Research Center and Department of Physics, Faculty of Science, Prince of Songkla University, Hatyai, Songkhla, 90112, Thailand

\section{ABSTRACT}

A hydrochemical study of $\mathrm{CO}_{2}$-rich groundwaters in Songkhla Province, Thailand has been carried out to understand the hydrochemical behavior of these waters and to identify the possible sources of their $\mathrm{CO}_{2}$. In this study, emphasis will be placed on systematic variations of the isotopic and chemical composition including rare earth elements (REE) fractionation patterns of $\mathrm{CO}_{2}$-rich groundwaters. These $\mathrm{CO}_{2}$-rich groundwaters are characterized by weakly acidic to neutral $\mathrm{pH}(6.5)$ associated with high $\mathrm{HCO}_{3}^{-}, \mathrm{SO}_{4}^{2-}, \mathrm{Cl}^{-}$contents and high total dissolved solids (TDS). The $\mathrm{CO}_{2}$-rich groundwaters contain very high concentrations of ions such as $\mathrm{Ca}^{2+}, \mathrm{Mg}^{2+}, \mathrm{K}^{+}$, and $\mathrm{Ba}^{2+}$. Upper continental crust (UCC) normalized REE patterns exhibited a slight heavy REE (HREE) enrichment with high positive Eu anomalies, which can be controlled by $\mathrm{SO}_{4}$ complexing in groundwater and plagioclase dissolution. Sr concentrations in $\mathrm{CO}_{2}$-rich groundwaters (1.30-1.37 ppm) are significantly higher than in non- $\mathrm{CO}_{2}$-rich groundwaters and surface water with concentrations of $0.007-0.014 \mathrm{ppm}$ and $0.017 \mathrm{ppm}$, respectively. $\mathrm{CO}_{2}$-rich groundwaters also showed a specific ${ }^{87} \mathrm{Sr} /{ }^{86} \mathrm{Sr}$ ratio of 0.726 , whereas the other water had values ranging from $0.725-0.731$. The ${ }^{3} \mathrm{H}$ amount ranging from 0.29 to $0.38 \mathrm{TU}$ indicate that 
$\mathrm{CO}_{2}$-rich groundwaters are submodern groundwater, which were recharged before 1950s; whereas non- $\mathrm{CO}_{2}$-rich groundwaters in the same area show higher ${ }^{3} \mathrm{H}$ amount (1.50-1.57 TU), which indicates mixing of submodern and modern groundwater. While the $\delta^{13} \mathrm{C}$ values $(-4.3$ and $-4.7 \%$ VPDB) indicated a deep seated mantel source for $\mathrm{CO}_{2}$.

\section{INTRODUCTION}

$\mathrm{CO}_{2}$-rich groundwaters have been found in many parts of the world (Négrel et al. 2000; Marques et al. 2001; Bao et al. 2008; Choi et al. 2009; Guo et al. 2010). They are normally characterized by higher $\mathrm{P}_{\mathrm{CO} 2}$, higher amounts of total dissolved solids (TDS), and precipitation of brown carbonates. They are dominantly found in volcanic or granitic rocks as cold or thermal springs (Choi et al. 2005). Many hypotheses about the $\mathrm{CO}_{2}$ sources have been proposed, e.g. magmatic sources, decomposition of organic matter, or the dissolution of carbonate minerals. However, there are only a few academic reports about $\mathrm{CO}_{2}$-rich groundwater in Thailand. Recently, $\mathrm{CO}_{2}$-rich groundwaters were accidentally found by drilling new boreholes for agricultural purposes and human consumption on a farm in Songkhla province, Southern Thailand. Their characteristics are similar to many $\mathrm{CO}_{2}$-rich waters in other regions of the world. They are slightly acidic, containing high TDS, and high $\mathrm{P}_{\mathrm{CO} 2}$, which is visible as gas in the waters. Interestingly, only two of the wells in the area show $\mathrm{CO}_{2}$-rich groundwaters. Nearby wells, located only 500 meters away, provide non $\mathrm{CO}_{2}$-rich groundwaters. Sources and evolution of these $\mathrm{CO}_{2}$-rich groundwaters are still unclear. In this study, analyses of major element, REE and isotopic composition $\left({ }^{3} \mathrm{H}, \delta^{13} \mathrm{C},{ }^{87} \mathrm{Sr} /{ }^{86} \mathrm{Sr}\right)$ were carried out to clarify the hydrochemical behavior of the $\mathrm{CO}_{2}$-rich groundwaters in this area and to identify possible sources of their $\mathrm{CO}_{2}$.

Hydrochemical characteristics of $\mathrm{CO}_{2}$-rich groundwaters have been intensively investigated in different parts of the world, e.g. China, France, Korea, and Portugal (Négrel et al. 2000; Marques et al. 2001; Bao et al. 2008; Choi et al. 2009; Guo et al. 2010). Rare earth elements (REE) have been used as a potential tracer in many groundwater studies to explain 
geochemical processes e.g. water-rock interaction and groundwater mixing process (Johannesson \& Hendry 2000; Négrel et al. 2000; Choi et al. 2009; Yuan et al. 2014). These studies showed that the REE abundances in groundwater depend on several factors e.g. rockforming minerals in aquifer materials, $\mathrm{pH}$, redox condition, complexing ligands in groundwater, and adsorption/desorption reactions. REEs behave generally coherent and their fractionation patterns can yield important information with regards to geochemical processes, which occur within the water-rock system.

\section{STUDY AREA}

The study area is in Khlong Hoi Khong at a royal research farm, which is located about $20 \mathrm{~km}$ southwest of Hat Yai City, Songkhla Province, Thailand. Many agricultural activities are carried out on this $1.28 \mathrm{~km}^{2}$ farm, e.g. cattle production, fruit tree plantations, and plant crop production. The study area is located in the central part of Hat Yai Basin (Fig. 1).

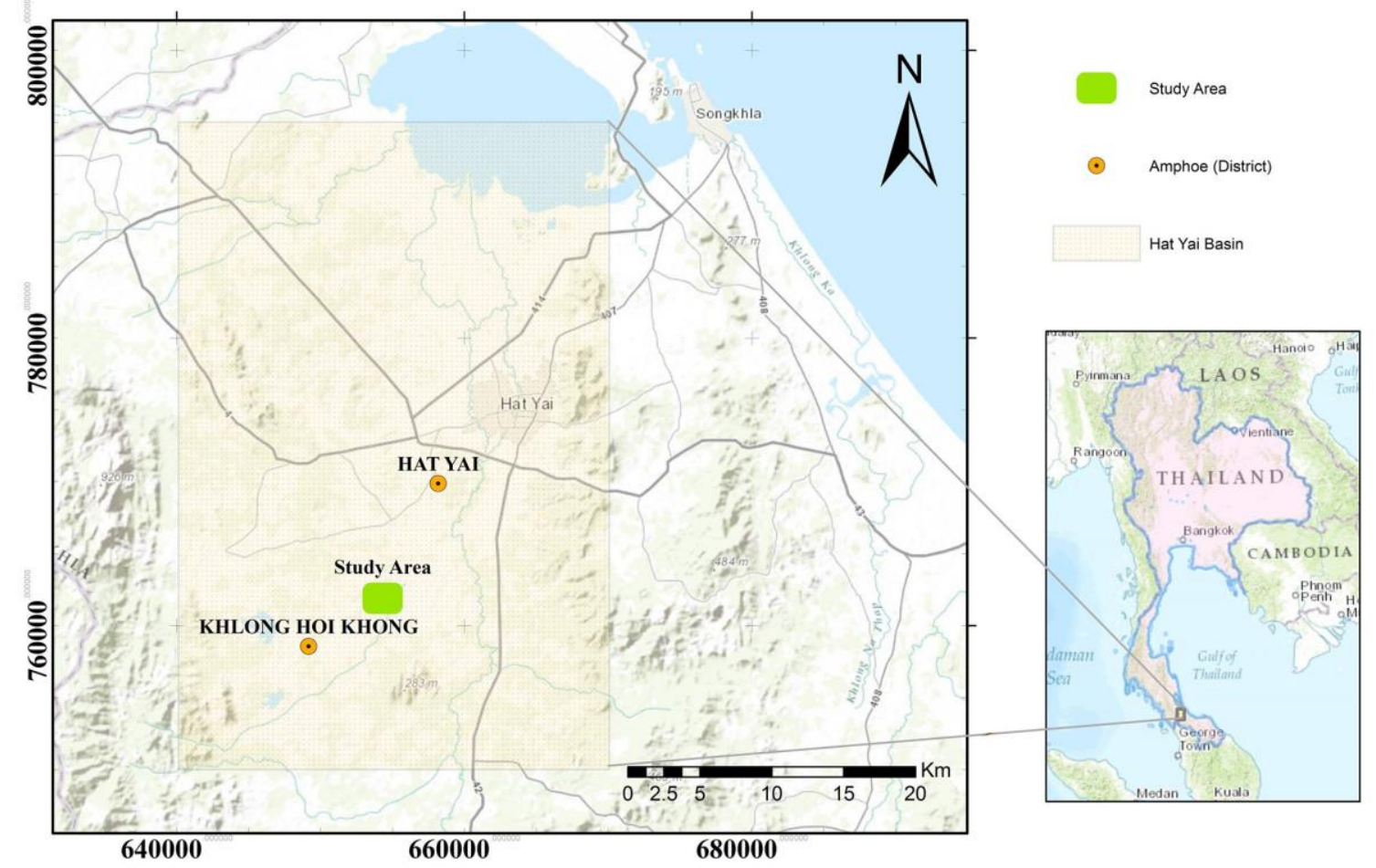

Figure 1. Topographic map of Hat Yai Basin, Songkhla Province, Thailand (modified after ESRI world topographic map). 
The Hat Yai Basin is thought to be a graben which is bounded at the east and west by mountain ranges, which are part of a horst system. U-Tapao is the main river system in this area, which is about $80 \mathrm{~km}$ long and flows from south to north into the Songkhla Lake. The Hat Yai Basin is a sedimentary basin ranging in age from Carboniferous to Quaternary. Granitic rocks intruded into Carboniferous and Triassic sedimentary rocks. Metamorphic rocks were found mainly at the eastern and western side of the basin, which form the basement of the basin (Lohawijarn 2005). Pegmanite, aplite, and quartz veins locally cut granites and sedimentary rocks. Carboniferous rocks are composed of sandstone, mudstone, chert, and quarzitic sandstone. Triassic rocks comprise of a red bed of conglomerates, sandstones, mudstones, and limestone. Late Triassic to early Jurassic granites are mainly coarse-grained porphyritic biotite and biotite-muscovite granites with quartz veins.

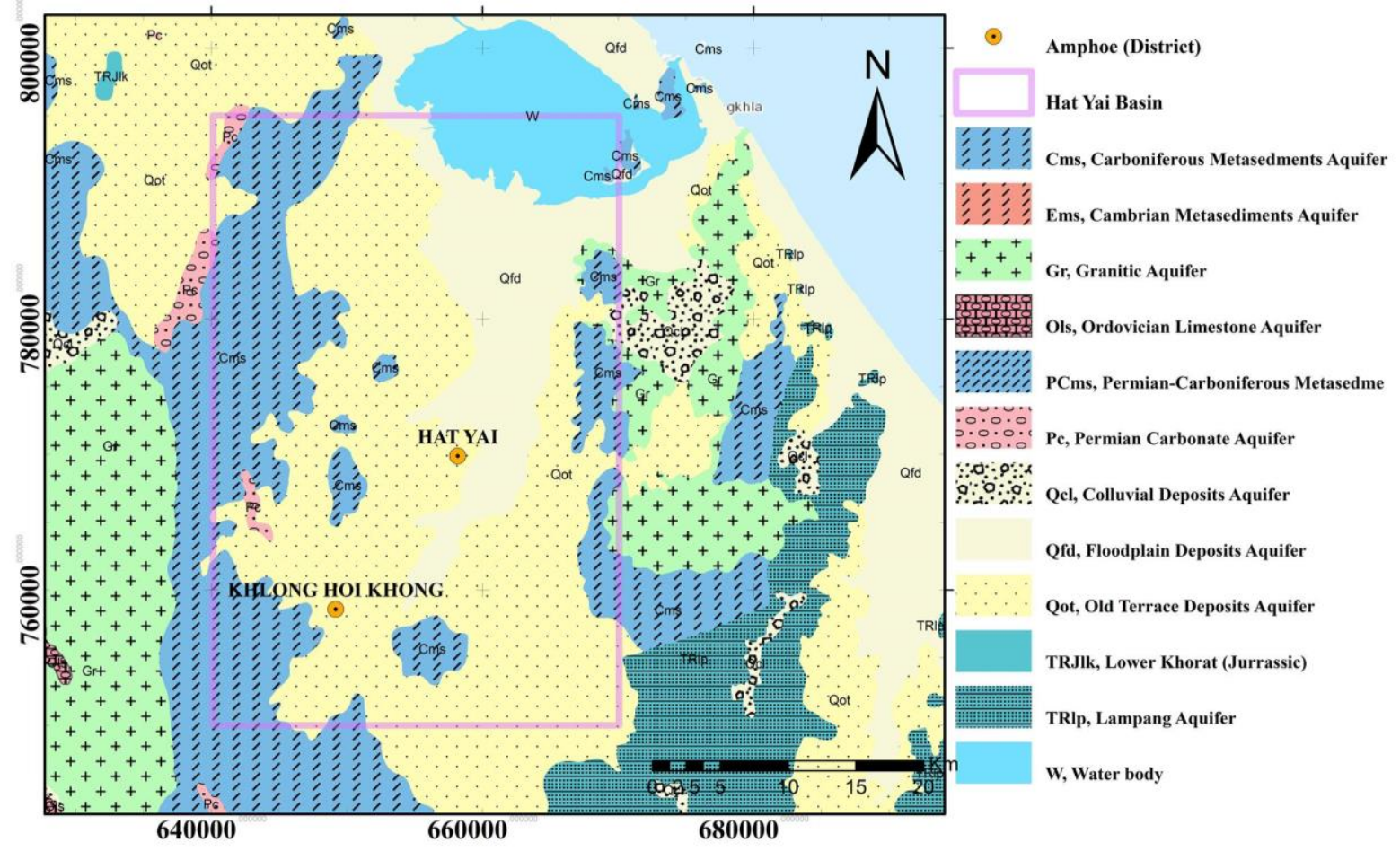

Figure 2. Hydrological map of Hat Yai Basin, Songkhla Province, Thailand (modified after the hydrogeological map of the Department of Groundwater Resources, Thailand).

The Hat Yai basin is overlain by thick Quaternary deposits with an age from 1.6 million years to present time (Fig. 2). The Quaternary alluvium composes of gravel, sand, silt, and clay (Wattanathum et al. 2004). The aquifer system comprises of unconsolidated and consolidated 
aquifers. There are three main aquifers in the Hat Yai Basin. The upper aquifer (Hat Yai aquifer) is an unconfined to semi-confined aquifer at a depth of 20 to $40 \mathrm{~m}$ (Lohawijarn 2005). This aquifer consists of moderately to well-sorted sand and gravel and is separated from the lower aquifer by a layer of low permeable clay. The lower aquifer (Khu Tao aquifer) is a confined aquifer, which consists of poorly sorted sand, gravel and several clay layers. The depth to the top of aquifer ranges from 50 to $100 \mathrm{~m}$. The deepest aquifer is the Khohong aquifer, which is deeper than $100 \mathrm{~m}$. It consists of unconsolidated and semi-consolidated clay, sand, and gravel. This aquifer is less productive (Buapeng 1990).

\section{SAMPLING AND ANALYTICAL METHODS}

To obtain hydrochemical and isotopic data, two samples of $\mathrm{CO}_{2}$-rich groundwater (D2, D4), two samples of non $\mathrm{CO}_{2}$-rich groundwater (D1, D9), one surface water sample, and four borehole cutting samples from a newly drilled groundwater borehole (D9) were collected. D1, D2, D4, and D9 are at 108, 128, 136, and 78 meter depth, respectively (Fig. 3).

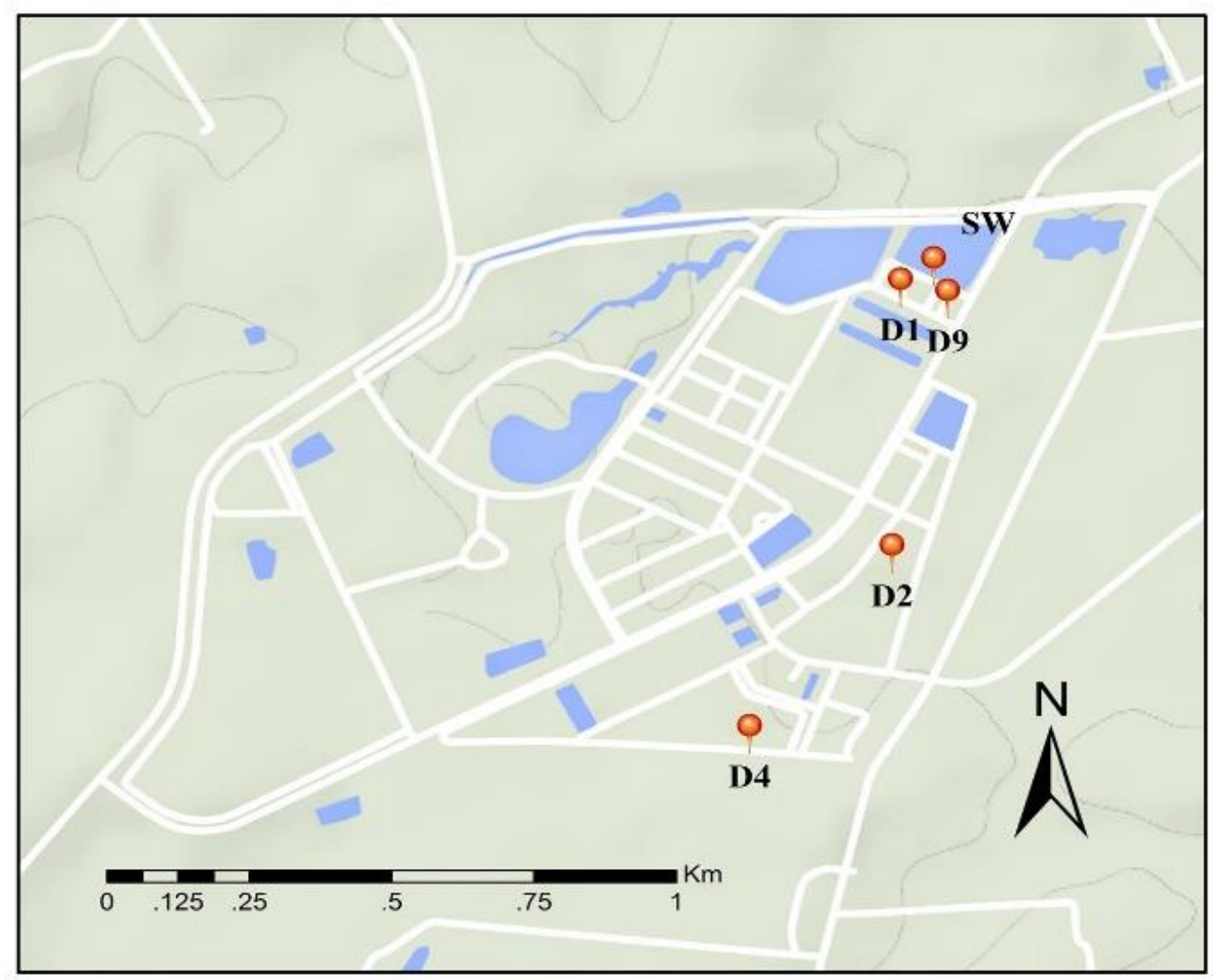

Figure 3. Sample locations: D1 and D9 are non- $\mathrm{CO}_{2}$-rich groundwaters; $\mathrm{D} 2$ and D4 are $\mathrm{CO}_{2}$-rich groundwaters; SW is surface water (modified after Google maps). 
All water samples for major cations, rare earth elements and Sr-isotope measurements were filtered through a $0.45 \mu \mathrm{m}$ membrane filter and acidified to $\mathrm{pH} 2$ with concentrated doubledistilled $\mathrm{HNO}_{3}$. Non-acidified water samples were collected for anions and Tritium $\left({ }^{3} \mathrm{H}\right)$ determination. For ${ }^{13} \mathrm{C}$ measurement, $\mathrm{NaOH}$ was added to water samples to $\mathrm{pH} 11$. The $\mathrm{BaCO}_{3}$ was precipitated after adding $\mathrm{BaCl}_{2}$ into the alkaline solution. These precipitates were removed from the residual water and oven-dried at $60^{\circ} \mathrm{C}$.

Major cations and anions were analyzed at the Central Equipment Division, Faculty of Science, Prince of Songkhla University (PSU, Thailand) using an ICP-OES, ion chromatography and titration method. Rare earth elements and ${ }^{13} \mathrm{C}$ were determined by ICPMS on a VG Plasma Quad II and Thermo Kiel IV with Finnigan DeltaPlus Mass Spectrometer, respectively, at the Geoscience Centre at University of Göttingen (GZG, Germany). Tritium $\left({ }^{3} \mathrm{H}\right)$ contents were analyzed by Liquid Scintillation Counter (Tricarb $3180 \mathrm{TR} / \mathrm{SL}$ ) after electrolytic enrichment at the Thailand Institute of Nuclear Technology (TINT). Sr concentrations were performed on a Thermo-Finnigan Triton ${ }^{\odot}$ TIMS at the Geoscience Centre at University of Göttingen (GZG, Germany). Prior to digestion, samples were mixed with a tracer solution enriched in ${ }^{87} \mathrm{Rb}-{ }^{84} \mathrm{Sr}$. Detailed description for the analytical procedure for water- and cutting samples are given in Wiegand et al. (2001), Tütken et al. (2002), and Klaus et al. (2007). Throughout this work a value of $0.710259 \pm 0.000076(2 \sigma)$ for the NBS $987(n=4)$ was observed. Instrumental mass fractionation was corrected with ${ }^{88} \mathrm{Sr} /{ }^{86} \mathrm{Sr}$ of 0.1194 using exponential law.

\section{RESULTS}

\subsection{Chemical composition of investigated groundwater}

Concentrations of major cations and anions of the four groundwater samples are summarized in Table 1. Results show that the investigated groundwaters can be classified as $\mathrm{Na}-\mathrm{Cl}$ type for non- $\mathrm{CO}_{2}$-rich groundwater (D1, D9) and as $\mathrm{Na}-\mathrm{Ca}-\mathrm{HCO}_{3}$ type for $\mathrm{CO}_{2}$-rich groundwater (D2, D4). The concentrations of the most cations (e.g. $\mathrm{Ca}^{2+}, \mathrm{Mg}^{2+}, \mathrm{Na}^{+}, \mathrm{K}^{+}, \mathrm{Ba}^{2+}$ ) and anions (e.g. $\mathrm{Cl}^{-}, \mathrm{SO}_{4}{ }^{2-} \mathrm{HCO}_{3}{ }^{-}$) including total dissolved solids (TDS) of $\mathrm{CO}_{2}$-rich groundwater are 
significantly higher than that of non- $\mathrm{CO}_{2}$-rich groundwater. In both $\mathrm{CO}_{2}$-rich groundwater samples (D2 and D4) $\mathrm{HCO}_{3}{ }^{-}$is the dominant anion (1,658 and 1,756 mg/L, respectively), followed by $\mathrm{SO}_{4}{ }^{2-}$ (122 and $110 \mathrm{mg} / \mathrm{L}$, respectively).

Table 2. Hydrogeochemical data of the water samples collected in June 2013 from drilled well D1, D2, D4 and D9. Concentrations are in $\mathrm{mg} / \mathrm{L}$.

\begin{tabular}{|c|c|c|c|c|}
\hline & D1 & D2 & D4 & D9 \\
\hline $\mathrm{pH}$ & 5.69 & 6.34 & 6.39 & 5.63 \\
\hline $\mathrm{Fe}$ & 2.05 & 0.31 & 0.95 & 0.08 \\
\hline $\mathrm{Mn}$ & 0.03 & 0.14 & 0.12 & 0.07 \\
\hline $\mathrm{Ca}$ & 0.99 & 156.20 & 156.60 & 3.26 \\
\hline $\mathrm{Mg}$ & 0.52 & 66.15 & 79.32 & 1.37 \\
\hline $\mathrm{Na}$ & 6.62 & 190.90 & 175.50 & 10.66 \\
\hline $\mathrm{K}$ & 1.64 & 107.30 & 97.48 & 2.91 \\
\hline $\mathrm{Cu}$ & nd & nd & nd & 0.001 \\
\hline $\mathrm{Zn}$ & 0.23 & 0.053 & 0.005 & 0.03 \\
\hline $\mathrm{SO}_{4}$ & $<5$ & 122 & 110 & $<5$ \\
\hline $\mathrm{Cl}$ & 28.78 & 65.07 & 60.06 & 21.96 \\
\hline $\mathrm{F}$ & $<0.10$ & 0.38 & 0.48 & $<0.10$ \\
\hline $\mathrm{HCO}_{3}$ & 9.78 & 1658 & 1756 & 19.67 \\
\hline $\mathrm{NO}_{2}$ & nd & nd & nd & nd \\
\hline $\mathrm{NO}_{3}$ & nd & nd & nd & nd \\
\hline Total hardness & 5.36 & 696 & 696 & 12.5 \\
\hline TDS & 37.30 & 908 & 931 & 49.10 \\
\hline $\mathrm{Pb}$ & nd & 0.01 & nd & nd \\
\hline $\mathrm{Ba}$ & 0.03 & 4.09 & 4.18 & 0.06 \\
\hline
\end{tabular}

nd denotes not detected.

\subsection{Isotopic compositions of groundwater}

Isotopic compositions $\left(\mathrm{Sr},{ }^{13} \mathrm{C}\right.$, and $\left.{ }^{3} \mathrm{H}\right)$ of groundwater samples are presented in Table 2 . The isotopic abundances of ${ }^{13} \mathrm{C}$ are expressed in per mil (\%o) deviations ( $\delta$ value), which are the relative deviations from the respect standard value, defined as

$$
\delta=\left[\frac{\mathrm{R}_{\text {sample }}}{\mathrm{R}_{\text {standard }}}-1\right] \times 1,000 .
$$

R refers to ${ }^{13} \mathrm{C} /{ }^{12} \mathrm{C}$ to standards VPDB. Tritium $\left({ }^{3} \mathrm{H}\right)$ is measured in Tritium Units (TU), where $1 \mathrm{TU}$ is defined as the ratio of 1 tritium atom to $10^{18}$ hydrogen atoms. 
Table 3. Isotopic concentrations of groundwater (D1-D9) and surface water (SW) samples.

\begin{tabular}{|c|c|c|c|c|c|c|}
\hline \multirow[b]{2}{*}{ Sample } & \multicolumn{3}{|c|}{$\mathrm{Sr}$} & \multicolumn{2}{|c|}{${ }^{3} \mathrm{H}$} & \multirow{2}{*}{$\frac{\boldsymbol{\delta}^{13} \mathbf{C}}{\%{ }^{2} \text { PPD }}$} \\
\hline & $\begin{array}{c}\mathrm{Sr} \\
(\mu \mathrm{g} / \mathrm{g})\end{array}$ & ${ }^{87} \mathrm{Sr} /{ }^{86} \mathrm{Sr}$ & $2 \mathrm{se}$ & ${ }^{3} \mathrm{H}(\mathrm{TU})$ & 2 se & \\
\hline D1 & 0.0078 & 0.731643 & 0.000008 & 1.5 & 0.3 & -18.0 \\
\hline D2 & 1.3739 & 0.726619 & 0.000025 & 0.3 & 0.3 & -4.3 \\
\hline D4 & 1.2995 & 0.726711 & 0.000006 & 0.4 & 0.3 & -4.8 \\
\hline D9 & 0.0147 & 0.729146 & 0.000029 & 1.6 & 0.3 & -18.8 \\
\hline SW & 0.0175 & 0.725345 & 0.000010 & 1.5 & 0.3 & -11.4 \\
\hline
\end{tabular}

Sr concentrations in $\mathrm{CO}_{2}$-rich groundwater were obviously high, ranging from 1.30 to 1.37 $\mu \mathrm{g} / \mathrm{g}$. These concentrations are about 100 times higher than in non- $\mathrm{CO}_{2}$-rich groundwater. The ${ }^{87} \mathrm{Sr} /{ }^{86} \mathrm{Sr}$ ratio of D2 and D4 showed a specific value of 0.726 , whereas the ${ }^{87} \mathrm{Sr} /{ }^{86} \mathrm{Sr}$ ratios in the other waters ranged from 0.725 to 0.731 . The high concentrations of ${ }^{3} \mathrm{H}$ were found in $\mathrm{D} 1$, D9 and surface water. The ${ }^{3} \mathrm{H}$ amount in $\mathrm{CO}_{2}$-rich groundwater was about 4 times lower than in non- $\mathrm{CO}_{2}$-rich groundwater. The $\delta^{13} \mathrm{C}$ was significantly more depleted in D1, D9 and surface water than in D2 and D4. Table 3 shows the Sr concentrations and ${ }^{87} \mathrm{Sr} /{ }^{86} \mathrm{Sr}$ of the borehole sample from the well D9, which ranged from 4.6 to $60.0 \mu \mathrm{g} / \mathrm{g}$ and 0.74118 to 0.776916 , respectively.

Table 4. Sr isotopic analyses and rock unit description of borehole cutting samples from the new drilled well D9.

\begin{tabular}{cccccc}
\hline $\begin{array}{c}\text { borehole } \\
\text { samples }\end{array}$ & $\begin{array}{c}\text { depth } \\
(\mathbf{m})\end{array}$ & rock unit & ${ }^{87} \mathbf{S r} /{ }^{86} \mathbf{S r}$ & $\mathbf{2 s e}$ & $\begin{array}{c}\mathbf{S r} \\
(\boldsymbol{\mu g} / \mathbf{g})\end{array}$ \\
\hline D9-2 & $6-12$ & gravel & 0.776916 & 0.000032 & 4.60 \\
D9-4 & $18-36$ & clay & 0.743656 & 0.000019 & 60.03 \\
D9-6 & $42-48$ & clay & 0.751754 & 0.000021 & 43.90 \\
D9-8 & $61-78$ & gravely silt & 0.741177 & 0.000006 & 60.01 \\
\hline
\end{tabular}

\subsection{Stable Isotopes of water ( $D$ and $\left.{ }^{18} \mathrm{O}\right)$}

The compositions of $\mathrm{D}$ and ${ }^{18} \mathrm{O}$ in $\mathrm{CO}_{2}$-rich groundwater and non- $\mathrm{CO}_{2}$-rich groundwater were shown in Figure 4. The result showed that the $\delta^{18} \mathrm{O}$ and $\delta \mathrm{D}$ value of $\mathrm{CO}_{2}$-rich water and rainwater lie along the global meteoric water line. Where $\delta^{18} \mathrm{O}$ and $\delta \mathrm{D}$ become enriched in non soda water. 


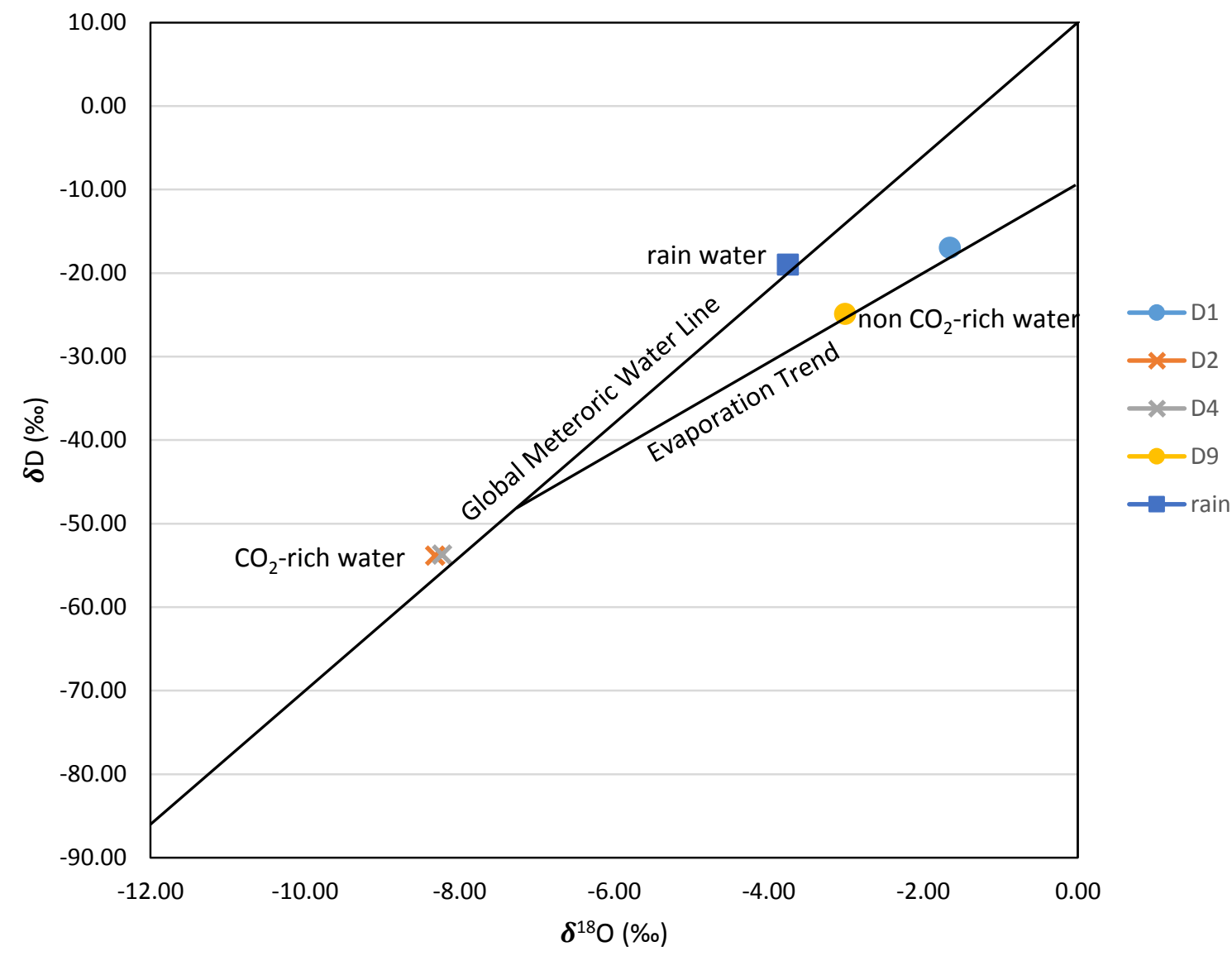

Figure 4. The compositions of $\mathrm{D}$ and ${ }^{18} \mathrm{O}$ in $\mathrm{CO}_{2}$-rich groundwater and non- $\mathrm{CO}_{2}$-rich groundwater.

\subsection{Rare earth elements (REE)}

REE abundances in groundwaters and surface water are normalized to the upper continental crust (UCC) and plotted on logarithmic scale as shown in Figure 5. Groundwater and surface water samples show a relatively flat to slightly enriched pattern in heavy REE (HREE) relative to the light REE (LREE). Europium (Eu) anomaly is defined after De Baar et al. (1985) as

$$
\mathrm{Eu} / \mathrm{Eu}^{*}=2 \mathrm{Eu}_{\mathrm{N}} /\left[\mathrm{Sm}_{\mathrm{N}}+\mathrm{Gd}_{\mathrm{N}}\right] \text {. }
$$

EuN, $\mathrm{Sm}_{\mathrm{N}}$, and GdN correspond to the UCC normalized concentration. Eu showed a slight positive anomaly with $\mathrm{Eu} / \mathrm{Eu}^{*}$ ranging from 1.97 to $2.95 \mathrm{in}$ non- $\mathrm{CO}_{2}$-rich groundwater and exhibited a slight negative anomaly $\left(\mathrm{Eu} / \mathrm{Eu}^{*}=0.77\right)$ in surface water. In contrast, the Eu anomaly of $\mathrm{CO}_{2}$-rich groundwater was significantly positive with $\mathrm{Eu} / \mathrm{Eu}^{*}$ values of 32.38 and 72.26 . 


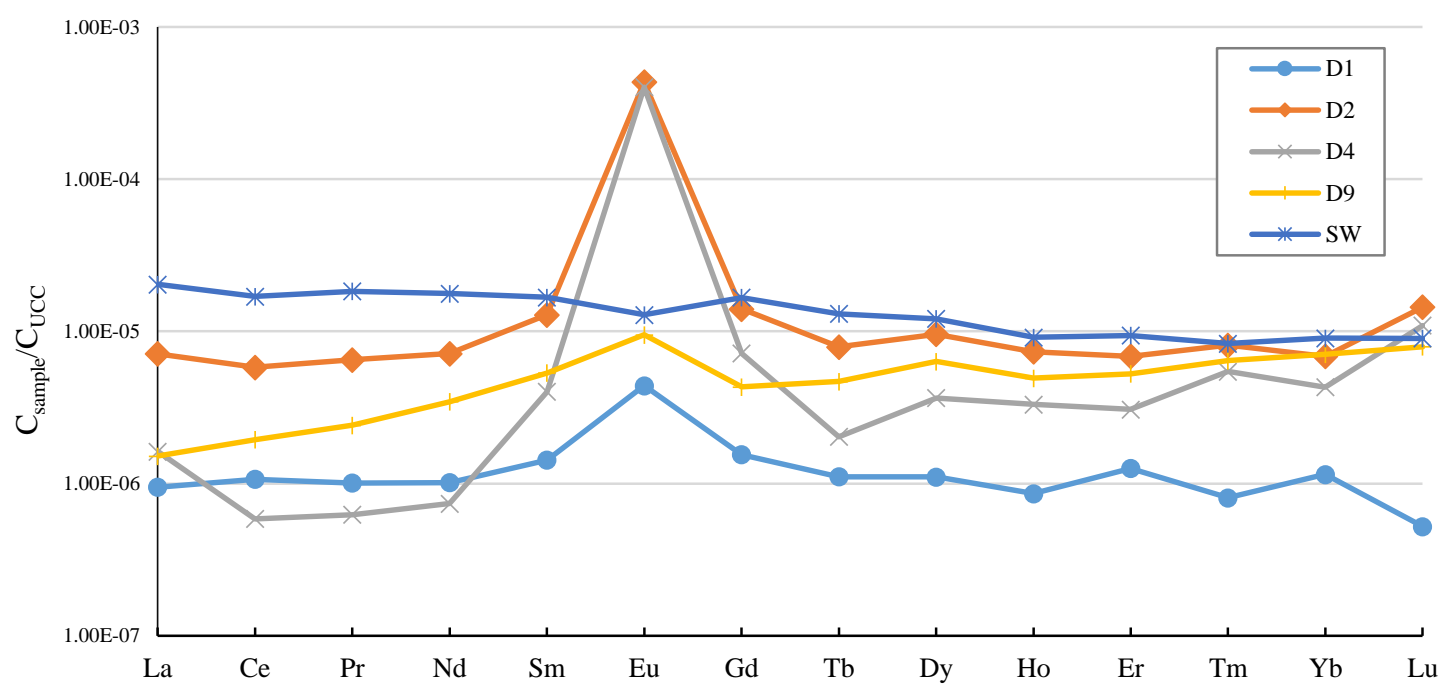

Figure 5. Upper continental crust (UCC) normalized REE patterns for groundwaters and surface water. The REE data were normalized to UCC (Taylor and McLennan 1981) and plotted in logarithmic scale. Most groundwater samples show slight HREE enrichment in relation to the UCC-normalized REE patterns. Surface water shows a slight LREE enrichment. High positive Eu Anomalies were found in $\mathrm{CO}_{2}$-rich groundwater.

\section{DISCUSSION}

The UCC-normalized REE patterns of $\mathrm{CO}_{2}$-rich groundwaters in this area are characterized by a slight HREE enrichment with high positive Eu anomalies. A hypothesis that has been proposed for explaining positive $\mathrm{Eu}$ anomalies in $\mathrm{CO}_{2}$-rich groundwaters is the preferred dissolution of Eu-enriched minerals (e.g. plagioclase) due to elevated concentrations in $\mathrm{Ca}$ and Sr. Shand et al. (2005) and Koh et al. (2008) suggested in their studies that positive Eu Anomalies in some groundwater correlate with high $\mathrm{Ca}$ and $\mathrm{Sr}$, indicating a plagioclase dissolution control. Our data seemed to confirm this. The low ${ }^{87} \mathrm{Sr} /{ }^{86} \mathrm{Sr}$ ratios with high $\mathrm{Sr}$ concentration in $\mathrm{CO}_{2}$-rich groundwaters may represent the progressive water-rock interaction, indicating an increasing component from plagioclase (low $\mathrm{Rb} / \mathrm{Sr}$ silicate) weathering (Négrel et al. 2001). Moreover, $\mathrm{Eu}^{3+}$ can be reduced to $\mathrm{Eu}^{2+}$ (under reducing condition) and the $\mathrm{Eu}$ anomalies can be controlled during water-rock interaction by the preferential mobilization of $\mathrm{Eu}^{2+}$ in aqueous solution compared to trivalent REEs. In addition, high positive Eu anomalies can be controlled by $\mathrm{SO}_{4}$ and $\mathrm{Cl}$ complexing in groundwater to form stable complexes of $\mathrm{EuSO}_{4}$ and $\mathrm{EuCl}_{2}$. 
The enrichment of these stable isotopes of water in non- $\mathrm{CO}_{2}$-rich groundwaters can be the result of evaporation effect. Because every water molecules are not the same due to different isotopic content. When surface water evaporates, isotopically lighter molecules evaporate preferentially. The heavier $\delta^{18} \mathrm{O}$ and $\delta \mathrm{D}$ become enriched in residual water. This evaporative signature is retained during infiltration into the aquifer. Therefore, groundwaters in D1, D9 Wells, which are non- $\mathrm{CO}_{2}$-rich groundwaters should be recharged from the evaporated surface water.

For $\mathrm{CO}_{2}$-rich groundwaters $\delta^{18} \mathrm{O}$ and $\delta \mathrm{D}$ value lie on global meteoric water line. But the valule have the trend in depleted value direction. This can be explained with continental rain out effect. The isotopic composition of rainwater gets lighter toward the continental interior and the precipitation gets lighter as the rain continues. Meteoric water which recharge this aquifer can be recharged from continental interior location by direct infiltration during major storm events, with minimal evaporation during recharge.

$\delta^{13} \mathrm{C}$ values of $\mathrm{CO}_{2}$-rich groundwaters in this area ranging from -4.8 to $-4.3 \%$ VPDB are in good agreement with the magmatic $\delta^{13} \mathrm{C}$ values, which are normally characterized by $\delta^{13} \mathrm{C}$ values between -10 and -3\% VPDB (Clark \& Fritz 1954). Tritium amount close to zero (0.29$0.38 \mathrm{TU}$ ) is an evidence of long residence time for water circulation exceeding 50 years. These hydrochemical and isotopic data indicate that the $\mathrm{CO}_{2}$-rich groundwaters were formed by the supply of deep-seated (magmatic) $\mathrm{CO}_{2}$ at depth and fed along a fault system to the relatively shallow aquifers.

Choi et al. (2009) showed similar results of $\mathrm{CO}_{2}$-rich groundwaters in Kangwon district, South Korea. Their data suggested that $\mathrm{Na}-\mathrm{HCO}_{3}$ type groundwater in that area were formed by active water-rock interaction at depth with long residence times, possibly even paleowater during colder climate condition due to low $\delta^{18} \mathrm{O}$ and $\delta \mathrm{D}$ and low tritium contents. 


\section{CONCLUSION}

The $\mathrm{CO}_{2}$-rich groundwaters in Khlong Hoi Khong in Songkhla Province, Thailand, are characterized by high $\mathrm{HCO}_{3}$, high TDS, and weak acidic to neutral $\mathrm{pH}$. Based on the isotopic and hydrochemical data we conclude that the difference in $\mathrm{CO}_{2}$ content in groundwaters in this area can be interpreted to be the result of tectonic activities, probably during the basin development, with the migration of deep $\mathrm{CO}_{2}$-rich waters along fault systems up to shallower aquifers.

\section{ACKNOWLEDGEMENTS}

The authors thank the Department of Groundwater Resources, Regional Office in Songkhla, and members of the Royal Research Farm, Thailand, for fieldwork support. We thank Prof. Pack and S. Sengupta for their help with the ${ }^{13} \mathrm{C}$ analyses, M. Döhmann for laboratory work and $\mathrm{M}$. Yongprawat for his help with ${ }^{3} \mathrm{H}$ analyses.

\section{REFERENCES}

Bao SX, Zhou HY, Peng XT, Ji FW and Yao HQ. 2008. Geochemistry of REE and Yttrium in Hydrothermal Fluids from the Endeavour Segment, Juan de Fuca Ridge. Geochemical Journal 42(4): 359-70.

Buapeng S. 1990. The Use of Environmental Isotopes on Groundwater Hydrology in the selected Areas in Thailand. Final report submitted to IAEA, Austria.

Choi HS, Koh WK, Bae DS, Park SS, Hutcheon I, Yun ST. 2005. Estimation of DeepReservoir Temperature of CO2-Rich Springs in Kangwon District, South Korea. Journal of Volcanology and Geothermal Research 141(1-2): 77-89.

Choi HS, Yun ST, Koh YK, Mayer B, Park SS, Hutcheon I. 2009. Geochemical Behavior of Rare Earth Elements during the Evolution of CO2-Rich Groundwater: A Study from the Kangwon District, South Korea. Chemical Geology 262: 318-27.

Clark ID and Fritz P. 1954. Environmental Isotopes in Hydrogeology. USA:CRC Press. $328 \mathrm{p}$

De Baar HJW, Bacon MP, Brewer PG and Bruland KW. 1985. Rare Earth Elements in Atlantic and Pacific Oceans, Geochim. Cosmochim. Acta 49: 1943-1959.

Guo H, Zhang B, Wang G and Shen Z. 2010. Geochemical Controls on Arsenic and Rare Earth Elements Approximately along a Groundwater Flow Path in the Shallow Aquifer of the Hetao Basin, Inner Mongolia. Chemical Geology 270(1-4): 117-25. 
Johannesson KH. and Hendry MJ. 2000. Rare Earth Element Geochemistry of

Groundwaters from a Thick till and Clay-Rich Aquitard Sequence, Saskatchewan, Canada. Geochimica et Cosmochimica Acta 64(9): 1493-1509.

Klaus JS, Hansen BT, Buapeng S. 2007. ${ }^{87} \mathrm{Sr} /{ }^{86} \mathrm{Sr}-$ Ratios: A Natural Tracer to characterize the Groundwater of Bangkok Area, Thailand, with respect to Public Water Supply and Freshwater Reinjection. Hydrogeology Journal 15: 745-758.

Koh YK, Choi BY, Yun ST, Choi HS, Mayer B and Ryoo SW. 2008. Origin and evolution of two contrasting thermal groundwaters (CO2-rich and alkaline) in the Jungwon area, South Korea: Hydrochemical and isotopic evidence. Journal of Volcanology and Geothermal Research 178: 777-786.

Lohawijarn W. 2005. Potential Ground Water Resources of Hat Yai Basin in Peninsular Thailand by Gravity Study. Songkhlanakarin Journal of Science and Technology 27(3): 633-647.

Marques JM, Monteiro Santos FA, Graça RC, Castro R, Aires-Barros L, Mendes Victor LA. 2001. A Geochemical and Geophysical Approach to Derive a Conceptual Circulation Model of CO2-Rich Mineral Waters: A Case Study of Vilarelho Da Raia, Northern Portugal. Hydrogeology Journal 9(6): 584-96.

Négrel P, Fouillac C and Brach M. 1997. Occurrence of Mineral Water Springs in the Stream Channel of the Allier River (Massif Central, France): Chemical and Sr Isotope Constraints. Journal of Hydrology 203: 143-53. 


\section{CHAPTER 5}

\section{CONCLUSION}

The results of this study underline the important role of application isotope tracers in groundwater studies and confirm the general strength and potential of isotopes and water chemistry to determine the origin, age and flow paths of groundwater in hydrogeologic systems. This $\mathrm{PhD}$ thesis investigates the applications of tracers in groundwater aquifers.

Both chemical (including rare earth elements) and isotopes tracers provide new insights into hydrologic processes. Environmental isotopes, which has been used in this thesis can be classified in two main categories, namely: water isotopes and solute isotopes. Water isotopes ( $\mathrm{D}$ and ${ }^{18} \mathrm{O}$ ) are are integral constituents of water molecules and widely used for determination of water sources, movement of water and contribution of old and new water. It is based on the facts that waters recharged at different times, at different locations are often isotopically distinct and the oxygen and hydrogen isotopes of meteoric waters keep their distinctive isotopic fingerprints until they mix with different isotopic waters compostions. The solute isotopes $\left({ }^{87} \mathrm{Sr},{ }^{13} \mathrm{C}\right.$ and $\left.{ }^{34} \mathrm{~S}\right)$ are constituents that are dissolved in water and are commonly used in biochemistry and geochemical researches. The solute isotopes can provide information about minerals that contribute to water chemistry and reflect the reactions that are characteristic of specific flow paths. Isotope hydrogeologists have to assess the applicability of each isotopes to answer the question whether isotopic techniques can help to solve specific research problems. In this thesis, a multi-isotope approach has been used together with available chemical and hydrologic data in many aspects of groundwater studies.

The main results and conclusions are as follows:

1. Water isotopes are effective tracers of water sources. They can provide the information about the temperature and altitude at the time of recharge. However, groundwater flow path normally cannot be identified precisely by using only water isotopes data because waters in the same flow path can come from different sources. 
2. Tritium can be used to estimate relative age of groundwater (e.g. younger than 1960) and provide a proof of connectivity between groundwater aquifers.

3. To avoid ambiguous interpretations, several isotope tracers (especially solute isotopes) can be used to test hypotheses developed from interpretation of water chemistry and hydrological background.

4. Solute isotopes reflect the reactions occurred in the aquifers and can be used to proove possible geochemical reactions. Due to the fact that solute isotope ratios are less affected by processes than chemical concentrations. Therefore, the interpretations of changes in isotope ratios are less obscure than the changes in chemical concentrations.

5. In contrast to water isotopes, $\mathrm{Sr}$ isotopes do not undergo detectable thermodynamic fractionation. The ${ }^{87} \mathrm{Sr} /{ }^{86} \mathrm{Sr}$ ratios are mainly controlled by water-rock interactions and they are not complicated by changes in atmospheric sources due to the low content of Sr.

6. ${ }^{87} \mathrm{Sr} /{ }^{86} \mathrm{Sr}$ ratios of groundwater will reflect source of weathering associated with the weathering source along the flow paths. These ratios can be used to identify groundwater flow paths and mixing sources. Moreover, the amount of mixing components in both natural recharge and artificial recharge process can be also quantitative evaluated by calculating simple mixing of two or more end-members. The isotopic fingerprints of groundwater and surface water can be easily used to track the artificial recharge process, especially when the difference in ${ }^{87} \mathrm{Sr} /{ }^{86} \mathrm{Sr}$ ratios of the injected water and native groundwater are significant.

7. The Rb-Sr isotopic compositions of whole rock specimens from the aquifers can be used to identify the age of the host rock and evolution of aquifers.

8. It is difficult to determine mineral sources by weathering in groundwater with the Srisotope data alone. Sr-isotopes should be integrated with water chemistry in order to identify mineral sources and reactions in groundwater aquifers. 
9. The integration of chemical, isotopic and hydrogeological data provide very useful information about sources and reactions in groundwater aquifers by developing appropriate models.

\section{OUTLOOK}

The demand for fresh water is growing with increasing population. Therefore, we need creative ways to predict the availability and sustainability of our biggest freshwater reservoir on the earth. Isotope techniques can help us to manage groundwater better. For example, Srisotopes and water isotopes can be used to identify major sources of groundwater recharge and to predict where and how fast is groundwater moving. This information is very useful in arid regions, where groundwater is the only freshwater source. In Addition, isotope techniques can be used to assess the pollution risk, estimate saline intrusion into the aquifer, identification of contaminant sources and to track the illegal groundwater abstraction, which are serious problems now a days. These isotope data will provide very valuable information once appropriate models are developed. So far, isotope data and modeling had not been actually combined to solve problems in groundwater issues. In a further step, we want to establish a modeling of isotope data integrated with conventional hydrologic studies to make isotope techniques a powerful forecasting tool for sustainable management either in quantity or in quality of groundwater resources. 


\section{APPENDIX}

Appendix I. Sr-isotopic composition and REE concentration of water samples from ASR testing in year 2012 (Chapter 2).

\begin{tabular}{|c|c|c|c|c|c|c|c|c|c|c|}
\hline sample name & $\begin{array}{l}\text { sampling } \\
\text { date }\end{array}$ & ${ }^{87} \mathrm{Sr} /{ }^{86} \mathrm{Sr}$ & $2 \mathrm{se}$ & $\begin{array}{c}\mathrm{Sr} \\
(\mu \mathrm{g} / \mathrm{g})\end{array}$ & $1 / \mathrm{Sr}$ & La (ppb) & Ce (ppb) & $\begin{array}{c}\mathrm{Pr} \\
(\mathrm{ppb})\end{array}$ & Nd (ppb) & $\underset{(p p b)}{S m}$ \\
\hline MWS 1 & 16.10 .2012 & 0.70998 & 0.00096 & 0.094 & 10.6 & 0.039 & 0.081 & 0.010 & 0.037 & 0.008 \\
\hline MWS 2 & 16.10 .2012 & 0.71000 & 0.00069 & 0.104 & 9.6 & 0.062 & 0.122 & 0.014 & 0.056 & 0.011 \\
\hline MWS 3 & 16.10 .2012 & 0.71050 & 0.00214 & 0.109 & 9.2 & 0.027 & 0.054 & 0.006 & 0.022 & 0.006 \\
\hline MWS 4 & 16.10 .2012 & 0.70994 & 0.00045 & 0.101 & 9.9 & 0.045 & 0.094 & 0.012 & 0.048 & 0.013 \\
\hline MWS 5 & 16.10 .2012 & 0.70996 & 0.00035 & 0.105 & 9.5 & 0.037 & 0.066 & 0.009 & 0.028 & 0.006 \\
\hline MWS 6 & 16.10 .2012 & 0.70999 & 0.00107 & 0.108 & 9.2 & 2.284 & 4.745 & 0.604 & 2.378 & 0.515 \\
\hline MWS 7 & 16.10 .2012 & 0.70998 & 0.00070 & 0.109 & 9.2 & 0.042 & 0.074 & 0.010 & 0.039 & 0.008 \\
\hline MWS 8 & 16.10 .2012 & 0.71001 & 0.00194 & 0.103 & 9.7 & 0.033 & 0.073 & 0.008 & 0.035 & 0.007 \\
\hline MWD 1 & 16.10 .2012 & 0.70960 & 0.00057 & 0.113 & 8.8 & 0.079 & 0.157 & 0.020 & 0.079 & 0.016 \\
\hline MWD 2 & 16.10 .2012 & 0.70977 & 0.00219 & 0.113 & 8.9 & 0.437 & 0.956 & 0.119 & 0.463 & 0.108 \\
\hline MWD 3 & 16.10 .2012 & 0.70941 & 0.00098 & 0.154 & 6.5 & 0.079 & 0.177 & 0.020 & 0.081 & 0.018 \\
\hline MWD 4 & 16.10 .2012 & 0.70935 & 0.00214 & 0.123 & 8.1 & 0.079 & 0.177 & 0.020 & 0.081 & 0.018 \\
\hline MWD 5 & 16.10 .2012 & 0.70936 & 0.00094 & 0.103 & 9.7 & 0.027 & 0.055 & 0.007 & 0.029 & 0.007 \\
\hline MWD 6 & 16.10 .2012 & 0.70935 & 0.00284 & 0.126 & 7.9 & 0.055 & 0.108 & 0.014 & 0.052 & 0.014 \\
\hline MWD 7 & 16.10 .2012 & 0.70938 & 0.00043 & 0.132 & 7.6 & 0.014 & 0.021 & 0.002 & 0.011 & 0.003 \\
\hline MWD 8 & 16.10 .2012 & 0.70917 & 0.00069 & 0.135 & 7.4 & 0.064 & 0.130 & 0.016 & 0.064 & 0.015 \\
\hline MWD 1 & 17.11 .2012 & 0.70952 & 0.00091 & 0.130 & 7.7 & 0.008 & 0.010 & 0.001 & 0.005 & 0.002 \\
\hline MWD 2 & 17.11 .2012 & 0.70962 & 0.00041 & 0.125 & 8.0 & 0.024 & 0.040 & 0.004 & 0.015 & 0.004 \\
\hline MWD 3 & 17.11 .2012 & 0.70943 & 0.00015 & 0.163 & 6.1 & 0.030 & 0.039 & 0.002 & 0.009 & 0.003 \\
\hline MWD 4 & 17.11 .2012 & 0.70924 & 0.00165 & 0.123 & 8.1 & 0.031 & 0.056 & 0.005 & 0.018 & 0.006 \\
\hline MWD 5 & 17.11 .2012 & 0.70922 & 0.00027 & 0.127 & 7.8 & 0.010 & 0.015 & 0.002 & 0.005 & 0.002 \\
\hline MWD 6 & 17.11 .2012 & 0.70935 & 0.00085 & 0.157 & 6.4 & 0.011 & 0.015 & 0.002 & 0.007 & 0.002 \\
\hline MWD 7 & 17.11 .2012 & 0.70939 & 0.00083 & 0.139 & 7.2 & 0.011 & 0.013 & 0.001 & 0.005 & 0.002 \\
\hline MWD 8 & 17.11 .2012 & 0.70945 & 0.00070 & 0.096 & 10.4 & 0.041 & 0.069 & 0.007 & 0.027 & 0.006 \\
\hline Yom river & 16.10 .2012 & 0.70943 & 0.00085 & 0.205 & 4.9 & 0.694 & 1.427 & 0.186 & 0.750 & 0.165 \\
\hline Yom River & 17.11 .2012 & 0.70920 & 0.00050 & 0.203 & 4.9 & 0.273 & 0.502 & 0.067 & 0.281 & 0.065 \\
\hline Injected Water & 16.10 .2012 & 0.70929 & 0.00055 & 0.221 & 4.5 & 0.009 & 0.013 & 0.002 & 0.011 & 0.002 \\
\hline
\end{tabular}


Appendix II. Sr-isotopic composition, $\delta^{18} \mathrm{O}, \delta \mathrm{D}$ and anion concentration of water samples from ASR long term testing in year 2013 (Chapter 2).

\begin{tabular}{|c|c|c|c|c|c|c|c|c|c|c|c|c|}
\hline sample & event & ${ }^{87} \mathrm{Sr} /{ }^{86} \mathrm{Sr}$ & 2 se & $\underset{(\mu \mathrm{g} / \mathrm{g})}{\mathrm{Sr}}$ & $\begin{array}{l}\delta^{18} O \\
(\%)\end{array}$ & $\begin{array}{c}\delta D \\
(\% 0)\end{array}$ & $\begin{array}{c}\mathrm{Br} \\
(\mathrm{ppm})\end{array}$ & $\underset{(p p m)}{\mathrm{Cl}}$ & $\begin{array}{c}\mathbf{F} \\
(\mathbf{p p m})\end{array}$ & $\begin{array}{c}\mathrm{NO}_{3} \\
(\mathrm{ppm})\end{array}$ & $\begin{array}{c}\mathrm{PO}_{4} \\
(\mathrm{ppm})\end{array}$ & $\begin{array}{c}\mathrm{SO}_{4} \\
\text { (ppm) }\end{array}$ \\
\hline \multirow{7}{*}{ MWS1 } & 0 & 0.70967 & 0.00007 & 0.102 & -7.8 & -57.5 & n.a. & 5.5 & 0.2 & 1.1 & n.a. & n.a. \\
\hline & 1 & 0.70993 & 0.00001 & 0.081 & -6.0 & -43.7 & n.a. & 22.9 & 0.2 & 1.1 & n.a. & 9.7 \\
\hline & 2 & 0.71018 & 0.00002 & 0.097 & -6.2 & -49.3 & n.a. & 23.9 & 0.4 & 0.7 & n.a. & 10.2 \\
\hline & 3 & 0.70994 & 0.00002 & 0.097 & -5.8 & -46.9 & n.a. & 19.5 & 0.2 & 1.1 & n.a. & 12.6 \\
\hline & 4 & 0.71001 & 0.00004 & 0.092 & -7.5 & -53.9 & n.a. & 21.6 & 0.3 & 0.2 & n.a. & 11.1 \\
\hline & 5 & 0.70999 & 0.00002 & 0.090 & -7.4 & -53.9 & n.a. & 17.5 & 0.3 & 2.4 & n.a. & 8.9 \\
\hline & 6 & 0.70995 & 0.00001 & 0.095 & -7.8 & -56.5 & n.a. & 11.5 & 0.3 & 1.1 & n.a. & 7.3 \\
\hline \multirow{7}{*}{ MWS2 } & 0 & 0.71050 & 0.00006 & 0.099 & -8.0 & -58.6 & n.a. & 4.6 & 0.2 & 1.1 & n.a. & 7.8 \\
\hline & 1 & 0.70999 & 0.00002 & 0.087 & -6.6 & -48.1 & n.a. & 19.8 & 0.2 & 2.2 & n.a. & 12.5 \\
\hline & 2 & 0.71003 & 0.00003 & 0.089 & -7.1 & -51.9 & n.a. & 21.4 & 0.4 & 0.9 & n.a. & 11.4 \\
\hline & 3 & 0.70999 & 0.00003 & 0.086 & -7.3 & -52.6 & n.a. & 21.9 & 0.4 & 1.0 & n.a. & 11.6 \\
\hline & 4 & 0.71001 & 0.00001 & 0.092 & -7.4 & -53.6 & n.a. & 20.4 & 0.3 & 1.1 & n.a. & 12.0 \\
\hline & 5 & 0.70999 & 0.00002 & 0.090 & -7.6 & -56.6 & n.a. & 10.6 & 0.6 & 2.1 & n.a. & 8.8 \\
\hline & 6 & 0.70999 & 0.00001 & 0.101 & -8.0 & -58.6 & n.a. & 7.8 & 0.3 & 1.2 & n.a. & 7.3 \\
\hline \multirow{7}{*}{ MWS3 } & 0 & 0.70987 & 0.00004 & 0.117 & -7.7 & -57.3 & n.a. & 6.8 & 0.2 & 4.3 & n.a. & 4.4 \\
\hline & 1 & 0.70956 & 0.00002 & 0.142 & -6.6 & -47.3 & n.a. & 23.1 & 0.1 & 1.7 & n.a. & 10.8 \\
\hline & 2 & 0.71028 & 0.00006 & 0.169 & -7.2 & -52.3 & n.a. & 23.9 & 0.4 & 1.6 & n.a. & 10.9 \\
\hline & 3 & 0.70956 & 0.00004 & 0.152 & -7.2 & -51.7 & n.a. & 19.1 & 0.3 & 1.2 & n.a. & 11.7 \\
\hline & 4 & 0.70957 & 0.00003 & 0.147 & -7.3 & -52.5 & n.a. & 17.9 & 0.2 & 0.8 & n.a. & 11.1 \\
\hline & 5 & 0.70980 & 0.00002 & 0.113 & -7.7 & -56.8 & n.a. & 9.7 & 0.4 & 1.7 & n.a. & 6.0 \\
\hline & 6 & 0.71004 & 0.00004 & 0.111 & -8.0 & -59.3 & n.a. & 6.3 & 0.3 & 1.0 & n.a. & 5.2 \\
\hline \multirow{7}{*}{ MWS4 } & 0 & 0.71006 & 0.00003 & 0.102 & -7.1 & -52.6 & 0.2 & 10.1 & 0.2 & 0.5 & n.a. & 8.1 \\
\hline & 1 & 0.70991 & 0.00004 & 0.091 & -7.4 & -54.6 & n.a. & 11.5 & 0.2 & 1.9 & n.a. & 11.4 \\
\hline & 2 & - & - & - & - & - & - & - & - & - & - & - \\
\hline & 3 & 0.71000 & 0.00002 & 0.088 & -7.6 & -55.6 & n.a. & 13.8 & 0.3 & 1.5 & n.a. & 13.4 \\
\hline & 4 & 0.71014 & 0.00003 & 0.089 & -7.5 & -55.2 & n.a. & 13.8 & 0.3 & 0.9 & n.a. & 13.9 \\
\hline & 5 & 0.70998 & 0.00002 & 0.096 & -7.8 & -57.6 & n.a. & 7.8 & 0.3 & 1.5 & n.a. & 6.0 \\
\hline & 6 & 0.71098 & 0.00005 & 0.094 & -8.1 & -58.6 & n.a. & 7.6 & 0.3 & 1.2 & n.a. & 4.4 \\
\hline \multirow{7}{*}{ MWS5 } & 0 & 0.70996 & 0.00008 & 0.108 & -8.0 & -59.0 & n.a. & 4.2 & 0.2 & 0.8 & 14.4 & 13.9 \\
\hline & 1 & 0.70998 & 0.00001 & 0.091 & -6.5 & -47.3 & n.a. & 11.2 & 0.2 & 1.4 & n.a. & 7.4 \\
\hline & 2 & - & - & - & - & - & - & - & - & - & - & - \\
\hline & 3 & 0.70997 & 0.00003 & 0.088 & -7.6 & -55.4 & n.a. & 16.3 & 0.7 & 1.3 & n.a. & 7.8 \\
\hline & 4 & 0.70999 & 0.00002 & 0.084 & -7.6 & -55.7 & n.a. & 12.4 & 0.4 & 1.0 & n.a. & 5.1 \\
\hline & 5 & 0.70997 & 0.00002 & 0.088 & -7.6 & -56.4 & n.a. & 12.0 & 0.4 & 3.4 & 2.8 & 5.0 \\
\hline & 6 & 0.70998 & 0.00001 & 0.095 & -8.0 & -58.6 & n.a. & 6.9 & 0.3 & 1.2 & n.a. & - \\
\hline
\end{tabular}




\begin{tabular}{|c|c|c|c|c|c|c|c|c|c|c|c|c|}
\hline sample & event & ${ }^{87} \mathrm{Sr} /{ }^{86} \mathrm{Sr}$ & $2 \mathrm{se}$ & $\underset{(\mu \mathrm{g} / \mathrm{g})}{\mathrm{Sr}}$ & $\begin{array}{l}\delta^{18} 0 \\
(\% 0)\end{array}$ & $\begin{array}{l}\delta D \\
(\% 0)\end{array}$ & $\begin{array}{c}\mathrm{Br} \\
(\mathrm{ppm})\end{array}$ & $\begin{array}{c}\mathrm{Cl} \\
(\mathrm{ppm})\end{array}$ & $\begin{array}{c}\mathbf{F} \\
(\mathrm{ppm})\end{array}$ & $\begin{array}{c}\mathrm{NO}_{3} \\
(\mathrm{ppm})\end{array}$ & $\begin{array}{c}\mathrm{PO}_{4} \\
(\mathrm{ppm})\end{array}$ & $\begin{array}{c}\mathrm{SO}_{4} \\
\text { (ppm) }\end{array}$ \\
\hline \multirow{7}{*}{ MWS6 } & 0 & 0.71004 & 0.00005 & 0.109 & -8.0 & -58.3 & n.a. & 5.2 & 0.2 & 0.8 & n.a. & 3.8 \\
\hline & 1 & 0.71005 & 0.00003 & 0.077 & -4.8 & -42.2 & n.a. & 22.7 & 0.6 & 2.4 & n.a. & 6.9 \\
\hline & 2 & 0.71003 & 0.00004 & 0.088 & -6.9 & -50.4 & n.a. & 22.4 & 0.4 & 1.2 & n.a. & 12.7 \\
\hline & 3 & 0.71002 & 0.00004 & 0.080 & -7.5 & -54.5 & n.a. & 22.4 & 0.3 & 1.6 & n.a. & 7.5 \\
\hline & 4 & 0.70998 & 0.00005 & 0.086 & -7.5 & -54.4 & n.a. & 22.2 & 0.5 & 0.6 & n.a. & 6.6 \\
\hline & 5 & 0.71002 & 0.00001 & 0.090 & -7.1 & -52.2 & n.a. & 17.7 & 0.3 & 3.1 & n.a. & 5.6 \\
\hline & 6 & 0.71000 & 0.00008 & 0.097 & -7.9 & -57.6 & n.a. & 8.7 & 0.3 & 1.4 & n.a. & 4.6 \\
\hline \multirow{7}{*}{ MWS7 } & 0 & 0.70997 & 0.00001 & 0.111 & -7.7 & -57.2 & n.a. & 6.8 & 0.2 & 1.7 & n.a. & 4.7 \\
\hline & 1 & 0.70994 & 0.00001 & 0.079 & -5.9 & -44.5 & n.a. & 21.6 & 0.2 & 1.9 & n.a. & 11.5 \\
\hline & 2 & 0.71061 & 0.00004 & 0.081 & -7.1 & -51.5 & n.a. & 23.5 & 0.4 & 0.9 & n.a. & 11.7 \\
\hline & 3 & 0.70997 & 0.00007 & 0.076 & -7.5 & -54.1 & n.a. & 22.5 & 0.3 & 1.4 & n.a. & 12.1 \\
\hline & 4 & 0.70992 & 0.00002 & 0.082 & -7.3 & -53.3 & n.a. & 22.5 & 0.3 & 0.6 & n.a. & 11.7 \\
\hline & 5 & 0.70995 & 0.00001 & 0.092 & -7.6 & -55.6 & n.a. & 14.2 & 0.4 & 3.3 & n.a. & 9.1 \\
\hline & 6 & 0.71000 & 0.00004 & 0.100 & -7.9 & -58.3 & n.a. & 7.4 & 0.3 & 1.2 & n.a. & 6.5 \\
\hline \multirow{7}{*}{ MWS8 } & 0 & 0.71000 & 0.00001 & 0.106 & -8.0 & -58.9 & n.a. & 5.3 & 0.2 & 1.3 & n.a. & 9.5 \\
\hline & 1 & 0.70998 & 0.00001 & 0.100 & -6.6 & -48.2 & n.a. & 6.6 & 0.2 & 1.4 & n.a. & 11.6 \\
\hline & 2 & - & - & - & - & - & - & - & - & - & - & - \\
\hline & 3 & 0.70996 & 0.00005 & 0.093 & -7.3 & -54.0 & n.a. & 13.2 & 0.3 & 1.7 & n.a. & 11.8 \\
\hline & 4 & 0.70998 & 0.00002 & 0.096 & -7.5 & -55.3 & n.a. & 13.2 & 0.4 & 0.8 & n.a. & 11.7 \\
\hline & 5 & 0.70995 & 0.00002 & 0.103 & -7.9 & -58.6 & n.a. & 6.9 & 0.3 & 3.1 & n.a. & 7.4 \\
\hline & 6 & 0.71000 & 0.00002 & 0.096 & -8.2 & -60.1 & n.a. & 4.0 & 0.3 & 1.2 & n.a. & 5.8 \\
\hline \multirow{3}{*}{$\begin{array}{l}\text { injected } \\
\text { water }\end{array}$} & 1 & 0.70956 & 0.00001 & 0.173 & -4.5 & -38.7 & n.a. & 22.8 & 0.2 & 1.8 & n.a. & 13.7 \\
\hline & 2 & 0.70951 & 0.00003 & 0.132 & -5.2 & -41.3 & n.a. & 18.1 & 0.4 & 1.2 & n.a. & 11.9 \\
\hline & 3 & 0.70960 & 0.00001 & 0.126 & -6.4 & -47.4 & n.a. & 22.3 & 0.3 & 1.3 & n.a. & 12.9 \\
\hline \multirow{3}{*}{ Yom River } & 1 & 0.70953 & 0.00001 & 0.177 & -6.9 & -51.0 & n.a. & 5.0 & 0.2 & 1.5 & n.a. & 19.6 \\
\hline & 2 & 0.70978 & 0.00004 & 0.176 & -6.8 & -48.4 & n.a. & 5.8 & 0.4 & 1.3 & n.a. & 17.4 \\
\hline & 3 & 0.70934 & 0.00002 & 0.202 & -6.6 & -47.5 & n.a. & 4.9 & 0.3 & 1.0 & n.a. & 12.8 \\
\hline
\end{tabular}




\begin{tabular}{|c|c|c|c|c|c|c|c|c|c|c|c|c|}
\hline sample & event & ${ }^{87} \mathrm{Sr} /{ }^{86} \mathrm{Sr}$ & $2 \mathrm{se}$ & $\underset{(\mu \mathrm{g} / \mathrm{g})}{\mathrm{Sr}}$ & $\begin{array}{l}\delta^{18} O \\
(\%)\end{array}$ & $\begin{array}{l}\delta \mathrm{D} \\
(\% \circ)\end{array}$ & $\begin{array}{c}\mathrm{Br} \\
(\mathrm{ppm})\end{array}$ & $\underset{(p p m)}{C l}$ & $\begin{array}{c}\mathbf{F} \\
(\mathbf{p p m})\end{array}$ & $\begin{array}{c}\mathrm{NO}_{3} \\
(\mathrm{ppm})\end{array}$ & $\begin{array}{c}\mathrm{PO}_{4} \\
(\mathrm{ppm})\end{array}$ & $\underset{(\mathrm{ppm})}{\mathrm{SO}_{4}}$ \\
\hline & 0 & 0.70962 & 0.00004 & 0.118 & -7.31 & -53.60 & n.a. & 13.1 & 0.2 & 1.6 & n.a. & 4.0 \\
\hline & 1 & 0.70958 & 0.00005 & 0.115 & -6.94 & -52.24 & n.a. & 16.8 & 0.3 & 1.0 & n.a. & 10.8 \\
\hline & 2 & 0.70970 & 0.00002 & 0.111 & -6.64 & -49.31 & n.a. & 21.6 & 0.2 & 2.3 & n.a. & 5.5 \\
\hline \multirow[t]{7}{*}{ MWD1 } & 3 & 0.70972 & 0.00003 & 0.102 & -6.68 & -48.54 & n.a. & 22.8 & 0.4 & 1.3 & n.a. & 11.6 \\
\hline & 4 & 0.70947 & 0.00007 & 0.103 & -7.11 & -51.77 & n.a. & 20.5 & 0.3 & 0.4 & n.a. & 7.6 \\
\hline & 5 & 0.70952 & 0.00002 & 0.106 & -6.66 & -49.51 & n.a. & 23.5 & 0.4 & 2.5 & 2.8 & 17.7 \\
\hline & 6 & 0.70961 & 0.00003 & 0.112 & -7.29 & -53.44 & n.a. & 15.3 & 0.3 & 0.6 & n.a. & 15.2 \\
\hline & 0 & 0.70965 & 0.00002 & 0.128 & -7.21 & -53.03 & n.a. & 12.7 & 0.2 & 1.3 & n.a. & 12.2 \\
\hline & 1 & 0.70966 & 0.00002 & 0.106 & -6.95 & -51.63 & n.a. & 8.3 & 0.1 & 0.7 & n.a. & 17.0 \\
\hline & 2 & 0.70963 & 0.00004 & 0.098 & -6.34 & -46.40 & n.a. & 24.1 & 0.2 & 0.7 & 12.6 & 19.1 \\
\hline \multirow[t]{7}{*}{ MWD2 } & 3 & 0.70961 & 0.00003 & 0.100 & -6.68 & -48.52 & n.a. & 23.8 & 0.3 & 0.9 & n.a. & 19.2 \\
\hline & 4 & 0.70973 & 0.00003 & 0.098 & -7.23 & -52.71 & n.a. & 24.1 & 0.4 & 1.9 & n.a. & 15.4 \\
\hline & 5 & 0.70968 & 0.00002 & 0.098 & -6.58 & -48.57 & n.a. & 22.6 & 0.4 & 3.1 & n.a. & 18.1 \\
\hline & 6 & 0.70966 & 0.00003 & 0.112 & -7.08 & -51.98 & n.a. & 17.3 & 0.3 & 0.7 & n.a. & 16.4 \\
\hline & 0 & 0.70948 & 0.00002 & 0.134 & -7.34 & -53.90 & n.a. & 4.0 & 0.1 & 0.5 & n.a. & 14.0 \\
\hline & 1 & 0.70960 & 0.00007 & 0.107 & -6.27 & -46.75 & n.a. & 23.6 & 0.2 & 1.1 & n.a. & 7.3 \\
\hline & 2 & 0.70945 & 0.00001 & 0.127 & -6.04 & -43.14 & n.a. & 24.0 & 0.2 & 0.2 & n.a. & 19.5 \\
\hline \multirow[t]{7}{*}{ MWD3 } & 3 & 0.70946 & 0.00002 & 0.130 & -4.89 & -44.72 & n.a. & 24.1 & 0.4 & 0.6 & n.a. & 18.9 \\
\hline & 4 & 0.70948 & 0.00003 & 0.156 & -7.77 & -55.99 & n.a. & 23.1 & 0.2 & 0.3 & n.a. & 17.4 \\
\hline & 5 & 0.70941 & 0.00003 & 0.125 & -6.57 & -48.47 & n.a. & 23.4 & 0.4 & 1.1 & n.a. & 18.2 \\
\hline & 6 & 0.70939 & 0.00002 & 0.127 & -7.10 & -52.51 & n.a. & 16.2 & 0.5 & 0.5 & n.a. & 15.8 \\
\hline & 0 & 0.70923 & 0.00002 & 0.130 & -8.02 & -58.70 & n.a. & 5.0 & 0.2 & 1.7 & n.a. & 3.3 \\
\hline & 1 & - & - & - & - & - & - & - & - & - & - & - \\
\hline & 2 & 0.70923 & 0.00002 & 0.131 & -6.79 & -51.47 & 0.16 & 10.9 & 0.3 & 2.3 & n.a. & 19.8 \\
\hline \multirow[t]{7}{*}{ MWD4 } & 3 & - & - & - & - & - & - & - & - & - & - & - \\
\hline & 4 & 0.70923 & 0.00006 & 0.131 & -7.20 & -53.31 & 0.16 & 12.6 & 0.4 & 1.7 & n.a. & 18.2 \\
\hline & 5 & 0.70924 & 0.00002 & 0.126 & -7.17 & -53.23 & 0.16 & 12.0 & 0.3 & 1.6 & n.a. & 15.1 \\
\hline & 6 & 0.70919 & 0.00003 & 0.126 & -7.02 & -52.66 & 0.16 & 10.3 & 0.3 & 0.7 & - & - \\
\hline & 0 & 0.70940 & 0.00001 & 0.107 & -7.41 & -54.61 & n.a. & 7.7 & 0.2 & 0.6 & n.a. & 3.9 \\
\hline & 1 & - & - & - & - & - & - & - & - & - & - & - \\
\hline & 2 & 0.70940 & 0.00001 & 0.102 & -7.56 & -55.04 & n.a. & 7.4 & 0.2 & 1.6 & n.a. & 11.0 \\
\hline \multirow[t]{7}{*}{ MWD5 } & 3 & - & - & - & - & - & - & - & - & - & - & - \\
\hline & 4 & 0.70938 & 0.00003 & 0.099 & -7.80 & -57.04 & n.a. & 9.0 & 0.4 & 1.0 & n.a. & 12.7 \\
\hline & 5 & 0.70943 & 0.00002 & 0.115 & -7.53 & -55.19 & n.a. & 9.3 & 0.4 & 0.3 & n.a. & 13.8 \\
\hline & 6 & 0.70943 & 0.00002 & 0.109 & -7.24 & -53.89 & n.a. & 8.7 & 0.3 & 0.2 & n.a. & 13.6 \\
\hline & 0 & 0.70935 & 0.00002 & 0.130 & -7.15 & -52.94 & 0.16 & 10.6 & 0.2 & 1.4 & n.a. & 25.8 \\
\hline & 1 & 0.70940 & 0.00002 & 0.131 & -7.18 & -53.04 & n.a. & 12.9 & 0.3 & 1.5 & n.a. & 19.8 \\
\hline & 2 & 0.70933 & 0.00002 & 0.112 & -7.07 & -51.90 & n.a. & 18.7 & 0.4 & 1.7 & 14.1 & 25.2 \\
\hline \multirow[t]{4}{*}{ MWD6 } & 3 & 0.70934 & 0.00002 & 0.103 & -6.60 & -48.22 & n.a. & 23.3 & 0.5 & 0.6 & n.a. & 18.5 \\
\hline & 4 & 0.70964 & 0.00002 & 0.107 & -6.46 & -47.98 & n.a. & 14.0 & 0.2 & 1.1 & n.a. & 27.9 \\
\hline & 5 & 0.70939 & 0.00005 & 0.124 & - & - & n.a. & 17.0 & 0.4 & 1.2 & n.a. & 16.6 \\
\hline & 6 & 0.70936 & 0.00002 & 0.128 & -7.03 & -52.69 & n.a. & 9.0 & 0.1 & 0.7 & n.a. & 14.5 \\
\hline
\end{tabular}




\begin{tabular}{|c|c|c|c|c|c|c|c|c|c|c|c|c|}
\hline sample & event & ${ }^{87} \mathrm{Sr} /{ }^{86} \mathrm{Sr}$ & $2 \mathrm{se}$ & $\underset{(\mu \mathrm{g} / \mathrm{g})}{\mathrm{Sr}}$ & $\begin{array}{l}\delta^{18} O \\
(\%)\end{array}$ & $\begin{array}{l}\delta \mathrm{D} \\
(\% \circ)\end{array}$ & $\begin{array}{c}\mathrm{Br} \\
(\mathrm{ppm})\end{array}$ & $\underset{(p p m)}{\mathrm{Cl}}$ & $\begin{array}{c}\mathbf{F} \\
(\mathbf{p p m})\end{array}$ & $\begin{array}{c}\mathrm{NO}_{3} \\
(\mathrm{ppm})\end{array}$ & $\begin{array}{c}\mathrm{PO}_{4} \\
(\mathrm{ppm})\end{array}$ & $\underset{(\mathrm{ppm})}{\mathrm{SO}_{4}}$ \\
\hline & 0 & 0.70938 & 0.00001 & 0.133 & -7.00 & -52.22 & 0.16 & 11.2 & 0.2 & 1.2 & n.a. & 14.3 \\
\hline & 1 & 0.70938 & 0.00002 & 0.114 & -6.72 & -49.68 & n.a. & 24.8 & 0.3 & 1.1 & 14.0 & 13.0 \\
\hline & 2 & 0.70981 & 0.00006 & 0.103 & -4.68 & -39.65 & n.a. & 24.1 & 0.3 & 1.6 & n.a. & 16.2 \\
\hline \multirow[t]{7}{*}{ MWD7 } & 3 & 0.70945 & 0.00003 & 0.108 & -7.22 & -52.18 & n.a. & 24.1 & 0.3 & 0.9 & n.a. & 17.8 \\
\hline & 4 & 0.70944 & 0.00002 & 0.121 & -7.47 & -54.38 & n.a. & 23.5 & 0.3 & 1.0 & n.a. & 11.2 \\
\hline & 5 & 0.70939 & 0.00006 & 0.117 & -6.82 & -50.43 & n.a. & 19.2 & 0.3 & 1.5 & n.a. & 14.2 \\
\hline & 6 & 0.70933 & 0.00002 & 0.128 & -6.83 & -51.46 & 0.15 & 11.7 & 0.3 & 0.6 & n.a. & 13.9 \\
\hline & 0 & 0.70923 & 0.00002 & 0.134 & -7.13 & -52.88 & 0.15 & 11.3 & 0.2 & 2.0 & n.a. & 12.6 \\
\hline & 1 & - & - & - & - & - & - & - & - & - & - & - \\
\hline & 2 & 0.70919 & 0.00002 & 0.150 & -7.05 & -52.14 & 0.16 & 11.9 & 0.4 & 1.1 & n.a. & 20.3 \\
\hline \multirow[t]{4}{*}{ MWD8 } & 3 & - & - & - & - & - & - & - & - & - & - & - \\
\hline & 4 & 0.70921 & 0.00001 & 0.135 & -7.20 & -53.07 & n.a. & 16.6 & 0.3 & 1.8 & n.a. & 19.8 \\
\hline & 5 & 0.70922 & 0.00003 & 0.129 & -6.86 & -51.53 & 0.15 & 13.7 & 0.4 & 1.9 & n.a. & 17.1 \\
\hline & 6 & 0.70917 & 0.00002 & 0.121 & -7.24 & -53.54 & 0.16 & 11.1 & 0.3 & 0.5 & n.a. & 13.1 \\
\hline
\end{tabular}


Appendix III. REE concentration in deep aquifer, shallow aquifer, injected water and Yom River from ASR testing in year 2013 (Chapter 2).

\section{MWS}

\begin{tabular}{|c|c|c|c|c|c|c|c|c|}
\hline \multirow{2}{*}{$C(p p b)$} & \multirow{2}{*}{$\begin{array}{l}\text { sampling } \\
\text { date }\end{array}$} & \multirow{2}{*}{$\begin{array}{c}\begin{array}{c}\text { before } \\
\text { injection }\end{array} \\
3.08 .13\end{array}$} & \multicolumn{3}{|c|}{ injection } & \multirow{2}{*}{\begin{tabular}{|l} 
storage \\
13.10 .13
\end{tabular}} & \multicolumn{2}{|c|}{ extraction } \\
\hline & & & 12.09 .13 & 27.09 .13 & 9.10 .13 & & 8.11 .13 & 23.11 .13 \\
\hline MWS & event & 0 & 1 & 2 & 3 & 4 & 5 & 6 \\
\hline \multicolumn{9}{|l|}{ MWS1 } \\
\hline $\mathrm{La}$ & & 0.066 & 0.016 & 0.032 & 0.092 & 0.023 & 0.046 & 0.154 \\
\hline $\mathrm{Ce}$ & & 0.126 & 0.028 & 0.065 & 0.130 & 0.033 & 0.091 & 0.330 \\
\hline $\operatorname{Pr}$ & & 0.010 & 0.002 & 0.004 & 0.003 & 0.004 & 0.010 & 0.040 \\
\hline $\mathrm{Nd}$ & & 0.038 & 0.007 & 0.017 & 0.012 & 0.013 & 0.033 & 0.143 \\
\hline $\mathrm{Sm}$ & & 0.008 & 0.003 & 0.003 & 0.001 & 0.002 & 0.007 & 0.030 \\
\hline $\mathrm{Eu}$ & & 0.014 & 0.011 & 0.009 & 0.008 & 0.012 & 0.013 & 0.019 \\
\hline \multicolumn{9}{|l|}{ MWS 2} \\
\hline $\mathrm{La}$ & & 0.054 & 0.023 & 0.022 & 0.020 & 0.017 & 0.048 & 0.034 \\
\hline $\mathrm{Ce}$ & & 0.084 & 0.043 & 0.037 & 0.033 & 0.023 & 0.076 & 0.063 \\
\hline $\operatorname{Pr}$ & & 0.005 & 0.004 & 0.002 & 0.003 & 0.003 & 0.009 & 0.007 \\
\hline $\mathrm{Nd}$ & & 0.018 & 0.015 & 0.010 & 0.013 & 0.010 & 0.037 & 0.031 \\
\hline $\mathrm{Sm}$ & & 0.004 & 0.003 & 0.002 & 0.003 & 0.003 & 0.007 & 0.005 \\
\hline $\mathrm{Eu}$ & & 0.014 & 0.012 & 0.008 & 0.011 & 0.011 & 0.014 & 0.013 \\
\hline \multicolumn{9}{|l|}{ MWS 3} \\
\hline $\mathrm{La}$ & & 0.024 & 0.133 & 0.080 & 0.043 & 0.034 & 0.073 & 0.052 \\
\hline $\mathrm{Ce}$ & & 0.044 & 0.337 & 0.151 & 0.072 & 0.061 & 0.151 & 0.094 \\
\hline $\operatorname{Pr}$ & & 0.004 & 0.029 & 0.014 & 0.009 & 0.007 & 0.017 & 0.010 \\
\hline $\mathrm{Nd}$ & & 0.017 & 0.110 & 0.055 & 0.035 & 0.026 & 0.069 & 0.038 \\
\hline Sm & & 0.004 & 0.025 & 0.013 & 0.008 & 0.007 & 0.015 & 0.011 \\
\hline $\mathrm{Eu}$ & & 0.012 & 0.015 & 0.012 & 0.011 & 0.010 & 0.013 & 0.012 \\
\hline \multicolumn{9}{|l|}{ MWS 4} \\
\hline $\mathrm{La}$ & & 0.036 & 0.026 & - & 0.002 & 0.017 & 0.022 & 0.032 \\
\hline $\mathrm{Ce}$ & & 0.071 & 0.036 & - & 0.002 & 0.022 & 0.036 & 0.066 \\
\hline $\operatorname{Pr}$ & & 0.004 & 0.004 & - & 0.000 & 0.003 & 0.005 & 0.007 \\
\hline $\mathrm{Nd}$ & & 0.016 & 0.016 & - & 0.002 & 0.008 & 0.019 & 0.027 \\
\hline Sm & & 0.004 & 0.004 & - & 0.001 & 0.003 & 0.004 & 0.006 \\
\hline Eu & & 0.013 & 0.010 & - & 0.004 & 0.011 & 0.015 & 0.013 \\
\hline \multicolumn{9}{|l|}{ MWS 5} \\
\hline $\mathrm{La}$ & & 0.0289 & 0.0291 & - & 0.0615 & 0.0175 & 0.0373 & 0.0422 \\
\hline $\mathrm{Ce}$ & & 0.0540 & 0.0486 & - & 0.0985 & 0.0236 & 0.0770 & 0.0860 \\
\hline $\operatorname{Pr}$ & & 0.0043 & 0.0052 & - & 0.0110 & 0.0038 & 0.0092 & 0.0097 \\
\hline $\mathrm{Nd}$ & & 0.0190 & 0.0200 & - & 0.0455 & 0.0108 & 0.0327 & 0.0333 \\
\hline $\mathrm{Sm}$ & & 0.0042 & 0.0040 & - & 0.0094 & 0.0024 & 0.0061 & 0.0054 \\
\hline $\mathrm{Eu}$ & & 0.0122 & 0.0095 & - & 0.0124 & 0.0126 & 0.0135 & 0.0139 \\
\hline
\end{tabular}




\begin{tabular}{|c|c|c|c|c|c|c|c|c|}
\hline \multirow{2}{*}{ C (ppb) } & \multirow{2}{*}{$\begin{array}{l}\text { sampling } \\
\text { date }\end{array}$} & \multirow{2}{*}{$\begin{array}{c}\begin{array}{c}\text { before } \\
\text { injection }\end{array} \\
3.08 .13\end{array}$} & \multicolumn{3}{|c|}{ injection } & \multirow{2}{*}{$\begin{array}{l}\text { storage } \\
13.10 .13\end{array}$} & \multicolumn{2}{|c|}{ extraction } \\
\hline & & & 12.09 .13 & 27.09 .13 & 9.10 .13 & & 8.11 .13 & 23.11.13 \\
\hline MWS & event & 0 & 1 & 2 & 3 & 4 & 5 & 6 \\
\hline \multicolumn{9}{|l|}{ MWS 6} \\
\hline $\mathrm{La}$ & & 0.161 & 0.279 & 0.053 & 0.059 & 0.040 & 0.048 & 0.082 \\
\hline $\mathrm{Ce}$ & & 0.314 & 0.530 & 0.091 & 0.117 & 0.065 & 0.087 & 0.151 \\
\hline $\mathrm{Pr}$ & & 0.033 & 0.070 & 0.008 & 0.006 & 0.008 & 0.011 & 0.019 \\
\hline $\mathrm{Nd}$ & & 0.144 & 0.269 & 0.035 & 0.025 & 0.036 & 0.040 & 0.073 \\
\hline $\mathrm{Sm}$ & & 0.028 & 0.057 & 0.007 & 0.006 & 0.007 & 0.009 & 0.012 \\
\hline Eu & & 0.020 & 0.020 & 0.009 & 0.011 & 0.012 & 0.014 & 0.015 \\
\hline \multicolumn{9}{|l|}{ MWS 7} \\
\hline $\mathrm{La}$ & & 0.069 & 0.051 & 0.035 & 0.028 & 0.023 & 0.071 & 0.042 \\
\hline $\mathrm{Ce}$ & & 0.142 & 0.084 & 0.060 & 0.046 & 0.029 & 0.129 & 0.077 \\
\hline $\operatorname{Pr}$ & & 0.014 & 0.009 & 0.005 & 0.004 & 0.003 & 0.007 & 0.009 \\
\hline $\mathrm{Nd}$ & & 0.061 & 0.037 & 0.021 & 0.014 & 0.015 & 0.033 & 0.031 \\
\hline Sm & & 0.011 & 0.008 & 0.004 & 0.004 & 0.003 & 0.005 & 0.008 \\
\hline $\mathrm{Eu}$ & & 0.016 & 0.009 & 0.009 & 0.011 & 0.011 & 0.014 & 0.001 \\
\hline \multicolumn{9}{|l|}{ MWS 8} \\
\hline $\mathrm{La}$ & & 0.079 & 0.047 & - & 0.027 & 0.018 & 0.030 & 0.034 \\
\hline $\mathrm{Ce}$ & & 0.140 & 0.080 & - & 0.048 & 0.026 & 0.053 & 0.069 \\
\hline $\operatorname{Pr}$ & & 0.005 & 0.009 & - & 0.005 & 0.002 & 0.005 & 0.008 \\
\hline $\mathrm{Nd}$ & & 0.018 & 0.036 & - & 0.019 & 0.012 & 0.019 & 0.028 \\
\hline $\mathrm{Sm}$ & & 0.004 & 0.007 & - & 0.004 & 0.001 & 0.004 & 0.006 \\
\hline $\mathrm{Eu}$ & & 0.013 & 0.011 & - & 0.012 & 0.011 & 0.014 & 0.000 \\
\hline
\end{tabular}

MWD

\begin{tabular}{|c|c|c|c|c|c|c|c|c|}
\hline \multirow{2}{*}{ C (ppb) } & \multirow{2}{*}{$\begin{array}{c}\text { sampling } \\
\text { date }\end{array}$} & \multirow{2}{*}{$\begin{array}{c}\begin{array}{c}\text { before } \\
\text { injection }\end{array} \\
3.08 .13\end{array}$} & \multicolumn{3}{|c|}{ injection } & \multirow{2}{*}{$\begin{array}{l}\text { storage } \\
13.10 .13\end{array}$} & \multicolumn{2}{|c|}{ extraction } \\
\hline & & & 12.09 .13 & 27.09.13 & 9.10 .13 & & 8.11 .13 & 23.11.13 \\
\hline MWD & event & 0 & 1 & 2 & 3 & 4 & 5 & 6 \\
\hline \multicolumn{9}{|l|}{ MWD 1} \\
\hline $\mathrm{La}$ & & 0.018 & 0.017 & 0.040 & 0.031 & 0.021 & 0.027 & 0.030 \\
\hline $\mathrm{Ce}$ & & 0.029 & 0.029 & 0.075 & 0.049 & 0.029 & 0.044 & 0.045 \\
\hline $\operatorname{Pr}$ & & 0.002 & 0.003 & 0.006 & 0.004 & 0.003 & 0.004 & 0.004 \\
\hline $\mathrm{Nd}$ & & 0.009 & 0.009 & 0.029 & 0.017 & 0.009 & 0.016 & 0.016 \\
\hline $\mathrm{Sm}$ & & 0.003 & 0.003 & 0.005 & 0.003 & 0.003 & 0.004 & 0.003 \\
\hline $\mathrm{Eu}$ & & 0.016 & 0.015 & 0.012 & 0.012 & 0.013 & 0.015 & 0.014 \\
\hline \multicolumn{9}{|l|}{ MWD 2} \\
\hline $\mathrm{La}$ & & 0.043 & 0.039 & 0.044 & 0.033 & 0.036 & 0.158 & 0.031 \\
\hline $\mathrm{Ce}$ & & 0.084 & 0.078 & 0.085 & 0.064 & 0.063 & 0.307 & 0.046 \\
\hline $\operatorname{Pr}$ & & 0.009 & 0.008 & 0.009 & 0.005 & 0.007 & 0.036 & 0.005 \\
\hline $\mathrm{Nd}$ & & 0.037 & 0.034 & 0.035 & 0.019 & 0.025 & 0.141 & 0.024 \\
\hline $\mathrm{Sm}$ & & 0.008 & 0.008 & 0.010 & 0.004 & 0.007 & 0.029 & 0.004 \\
\hline $\mathrm{Eu}$ & & 0.017 & 0.015 & 0.011 & 0.010 & 0.015 & 0.021 & 0.016 \\
\hline
\end{tabular}




\begin{tabular}{|c|c|c|c|c|c|c|c|c|}
\hline \multirow{2}{*}{ C (ppb) } & \multirow{2}{*}{$\begin{array}{c}\text { sampling } \\
\text { date }\end{array}$} & \multirow{2}{*}{$\begin{array}{c}\begin{array}{c}\text { before } \\
\text { injection }\end{array} \\
3.08 .13\end{array}$} & \multicolumn{3}{|c|}{ injection } & \multirow{2}{*}{$\begin{array}{c}\text { storage } \\
13.10 .13\end{array}$} & \multicolumn{2}{|c|}{ extraction } \\
\hline & & & 12.09 .13 & 27.09.13 & 9.10 .13 & & 8.11 .13 & 23.11.13 \\
\hline MWD & event & 0 & 1 & 2 & 3 & 4 & 5 & 6 \\
\hline \multicolumn{9}{|l|}{ MWD 3} \\
\hline $\mathrm{La}$ & & 0.020 & 0.025 & 0.020 & 0.070 & 0.031 & 0.019 & 0.019 \\
\hline $\mathrm{Ce}$ & & 0.033 & 0.037 & 0.030 & 0.094 & 0.044 & 0.031 & 0.021 \\
\hline $\operatorname{Pr}$ & & 0.004 & 0.003 & 0.002 & 0.008 & 0.005 & 0.004 & 0.002 \\
\hline $\mathrm{Nd}$ & & 0.012 & 0.011 & 0.009 & 0.030 & 0.017 & 0.017 & 0.008 \\
\hline $\mathrm{Sm}$ & & 0.004 & 0.003 & 0.002 & 0.007 & 0.004 & 0.002 & 0.002 \\
\hline $\mathrm{Eu}$ & & 0.017 & 0.015 & 0.013 & 0.012 & 0.017 & 0.016 & 0.015 \\
\hline \multicolumn{9}{|l|}{ MWD 4} \\
\hline La & & 0.028 & - & 0.023 & - & 0.051 & 0.036 & 0.035 \\
\hline $\mathrm{Ce}$ & & 0.049 & - & 0.035 & - & 0.081 & 0.057 & 0.043 \\
\hline $\operatorname{Pr}$ & & 0.005 & - & 0.003 & - & 0.006 & 0.003 & 0.005 \\
\hline $\mathrm{Nd}$ & & 0.018 & - & 0.014 & - & 0.021 & 0.013 & 0.014 \\
\hline $\mathrm{Sm}$ & & 0.005 & - & 0.002 & - & 0.006 & 0.004 & 0.003 \\
\hline $\mathrm{Eu}$ & & 0.019 & - & 0.013 & - & 0.017 & 0.016 & 0.015 \\
\hline \multicolumn{9}{|l|}{ MWD 5} \\
\hline $\mathrm{La}$ & & 0.045 & - & 0.050 & - & 0.037 & 0.035 & 0.027 \\
\hline $\mathrm{Ce}$ & & 0.075 & - & 0.090 & - & 0.063 & 0.067 & 0.035 \\
\hline $\operatorname{Pr}$ & & 0.005 & - & 0.009 & - & 0.006 & 0.007 & 0.004 \\
\hline $\mathrm{Nd}$ & & 0.021 & - & 0.041 & - & 0.020 & 0.030 & 0.013 \\
\hline $\mathrm{Sm}$ & & 0.004 & - & 0.009 & - & 0.006 & 0.006 & 0.002 \\
\hline $\mathrm{Eu}$ & & 0.013 & - & 0.013 & - & 0.013 & 0.015 & 0.014 \\
\hline \multicolumn{9}{|l|}{ MWD 6} \\
\hline $\mathrm{La}$ & & 0.021 & 0.028 & 0.048 & 0.032 & 0.052 & 0.026 & 0.030 \\
\hline $\mathrm{Ce}$ & & 0.036 & 0.053 & 0.089 & 0.049 & 0.096 & 0.042 & 0.037 \\
\hline $\operatorname{Pr}$ & & 0.004 & 0.004 & 0.009 & 0.004 & 0.008 & 0.005 & 0.005 \\
\hline $\mathrm{Nd}$ & & 0.017 & 0.021 & 0.036 & 0.016 & 0.040 & 0.019 & 0.018 \\
\hline $\mathrm{Sm}$ & & 0.003 & 0.004 & 0.008 & 0.002 & 0.008 & 0.004 & 0.004 \\
\hline $\mathrm{Eu}$ & & 0.017 & 0.017 & 0.013 & 0.010 & 0.015 & 0.015 & 0.016 \\
\hline \multicolumn{9}{|l|}{ MWD 7} \\
\hline $\mathrm{La}$ & & 0.012 & 0.023 & 0.016 & 0.065 & 0.011 & 0.033 & 0.019 \\
\hline $\mathrm{Ce}$ & & 0.020 & 0.036 & 0.026 & 0.120 & 0.016 & 0.066 & 0.020 \\
\hline $\operatorname{Pr}$ & & 0.002 & 0.004 & 0.002 & 0.012 & 0.002 & 0.006 & 0.002 \\
\hline $\mathrm{Nd}$ & & 0.007 & 0.015 & 0.007 & 0.049 & 0.007 & 0.023 & 0.007 \\
\hline $\mathrm{Sm}$ & & 0.002 & 0.004 & 0.002 & 0.009 & 0.002 & 0.005 & 0.002 \\
\hline $\mathrm{Eu}$ & & 0.017 & 0.015 & 0.009 & 0.012 & 0.013 & 0.014 & 0.015 \\
\hline \multicolumn{9}{|l|}{ MWD 8} \\
\hline $\mathrm{La}$ & & 0.056 & - & 0.057 & - & 0.027 & 0.055 & 0.038 \\
\hline $\mathrm{Ce}$ & & 0.086 & - & 0.089 & - & 0.048 & 0.086 & 0.059 \\
\hline $\operatorname{Pr}$ & & 0.005 & - & 0.010 & - & 0.005 & 0.010 & 0.007 \\
\hline $\mathrm{Nd}$ & & 0.020 & - & 0.039 & - & 0.022 & 0.044 & 0.027 \\
\hline $\mathrm{Sm}$ & & 0.005 & - & 0.008 & - & 0.004 & 0.008 & 0.005 \\
\hline $\mathrm{Eu}$ & & 0.016 & - & 0.013 & - & 0.015 & 0.018 & 0.016 \\
\hline
\end{tabular}


Injected water

\begin{tabular}{l|llll}
\hline \multicolumn{1}{c|}{$\mathbf{C}(\mathbf{p p b})$} & sampling date & $\mathbf{3 . 0 8 . 1 3}$ & $\mathbf{2 8 . 0 8 . 1 3}$ & $\mathbf{1 2 . 0 9 . 1 3}$ \\
\hline injected water & 0.095 & 0.107 & 0.023 \\
$\mathrm{La}$ & 0.214 & 0.142 & 0.040 \\
$\mathrm{Ce}$ & 0.020 & 0.008 & 0.006 \\
$\mathrm{Pr}$ & 0.079 & 0.026 & 0.021 \\
$\mathrm{Nd}$ & 0.013 & 0.004 & 0.005 \\
$\mathrm{Sm}$ & 0.014 & 0.009 & 0.010 \\
$\mathrm{Eu}$
\end{tabular}

Yom River

\begin{tabular}{|c|c|c|c|c|c|c|}
\hline$C(p p b)$ & sampling date & 28.08 .13 & 11.09 .13 & 27.09 .13 & 9.10 .13 & 28.10 .13 \\
\hline \multicolumn{7}{|l|}{ Yom River } \\
\hline La & & 1.350 & 2.285 & 0.640 & 1.450 & 0.715 \\
\hline $\mathrm{Ce}$ & & 2.680 & 4.375 & 1.265 & 2.910 & 1.380 \\
\hline $\operatorname{Pr}$ & & 0.322 & 0.560 & 0.163 & 0.392 & 0.183 \\
\hline $\mathrm{Nd}$ & & 1.320 & 2.185 & 0.635 & 1.615 & 0.725 \\
\hline Sm & & 0.286 & 0.476 & 0.148 & 0.363 & 0.157 \\
\hline Eu & & 0.082 & 0.120 & 0.045 & 0.106 & 0.047 \\
\hline
\end{tabular}




\section{Lebenslauf}

\section{Persönliche Daten:}

Name: $\quad$ Manussawee Hengsuwan

Geboren am: 22.05.1985

In: $\quad$ Trang, Thailand

Nationalität: thailändisch

\section{Hochschulausbildung}

09/2015 - 06/2011 Studium der Chemie an der Georg-August-Universität Göttingen, Abschluss:

Diplom

05/2013 - 05/2016 Promotion Studiengang Geowissenschaften

Abteilung Isotopengeologie, Geowissenschaftliches Zentrum Gottingen,

Georg-August-Universität Göttingen

\section{Beruflicher Werdegang}

Seit 10/2011

Beamtin, Department of Groundwater Resources, Bangkok, Thailand. 